UNIVERSITY OF OKLAHOMA

GRADUATE COLLEGE

MISSISSIPPIAN MERAMEC LITHOLOGIES AND PETROPHYSICAL PROPERTY

VARIABILITY, STACK TREND, ANADARKO BASIN, OKLAHOMA

\author{
A THESIS \\ SUBMITTED TO THE GRADUATE FACULTY \\ In partial fulfillment of the requirements for the \\ Degree of \\ MASTER OF SCIENCE
}

By

MICHAEL MILLER

Norman, Oklahoma 2019 


\title{
MISSISSIPPIAN MERAMEC LITHOLOGIES AND PETROPHYSICAL PROPERTY VARIABILITY, STACK TREND, ANADARKO BASIN, OKLAHOMA
}

\author{
A THESIS APPROVED FOR THE
} CONOCOPHILLIPS SCHOOL OF GEOLOGY AND GEOPHYSICS

BY

Dr. Matthew J. Pranter, Chair

Dr. Deepak Devegowda

Dr. Kurt J. Marfurt 
(C) Copyright by MICHAEL MILLER 2019 All Rights Reserved. 


\section{ACKNOWLEDGEMENTS}

This research was funded through the United States Post 9/11 G.I. Bill, the Reservoir Characterization and Modeling Laboratory at the University of Oklahoma, and Marathon Oil Corporation. I thank Marathon Oil Corporation, Warwick Energy, Oklahoma Petroleum Information Center, and the Integrated Core Characterization Center for providing data. I thank Chris McLain and James Packwood from Marathon Oil Corporation for their valuable support and guidance throughout the project. I thank Dr. Carl Sondergeld, Dr. Chandra Rai for their guidance and support throughout this project as lead investigators. I thank Dick Larese, Dr. Ali Tinni, Ishank Gupta, Son Dang and Heyleem Han for thin-section point count, water saturation, rock type and XRF data respectively. I thank Schlumberger (Petrel and Techlog) and The Easycopy Company (EasyCore) for providing software. I thank Micaela Langevin for her support and assistance from the IC3 lab.

I would like to thank Dr. Matthew Pranter for his mentorship, support, patience and knowledge throughout the extent of the project. I would like to thank Dr. Deepak Devegowda and Dr. Kurt Marfurt for their input and support. I would like to thank my friends, fellow students and peers for their support, insight and contributions. Lastly, I would like to thank my girlfriend, Desiree Hullaster, who supported me through thick and thin these last two years. I could not have done it without you. 


\section{TABLE OF CONTENTS}

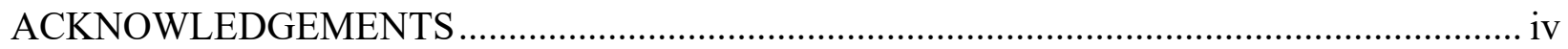

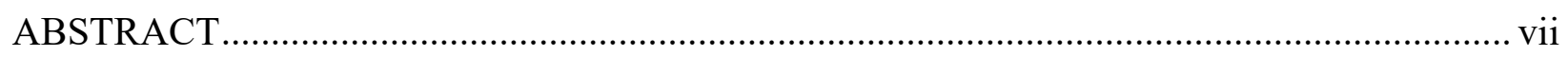

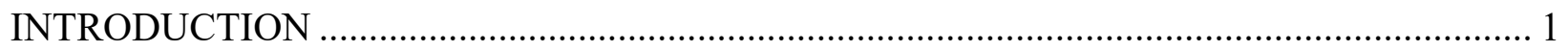

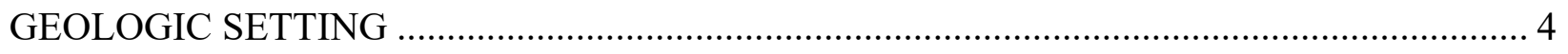

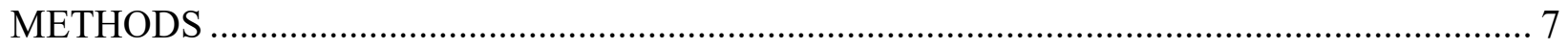

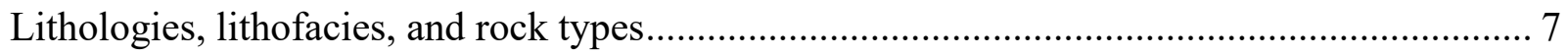

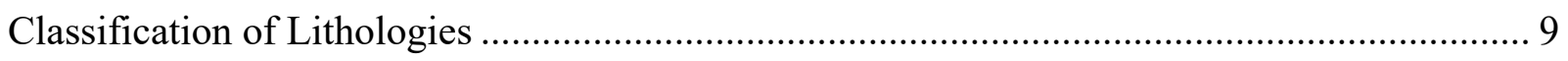

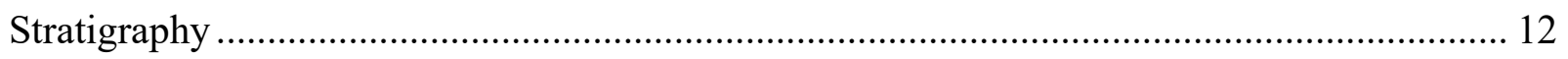

Lithology, Rock-Type, and Petrophysical-Property Modeling ................................................ 12

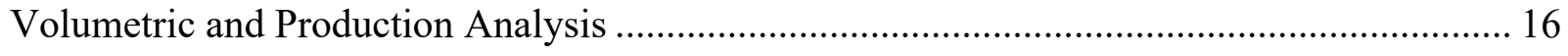

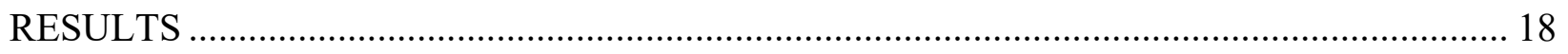

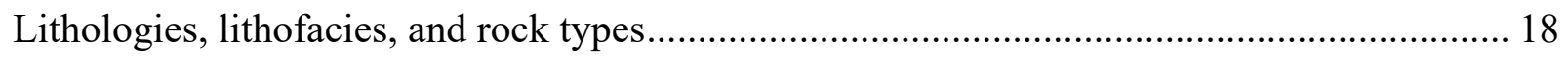

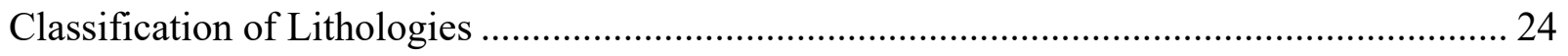

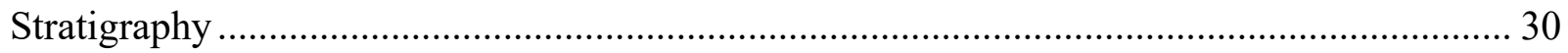

Lithology, Rock-Type, and Petrophysical-Property Models .................................................. 32

Volumetric and Production Analysis ................................................................................... 42

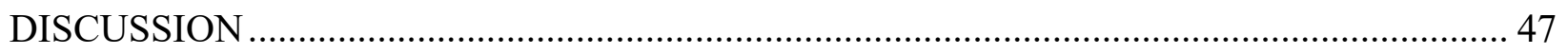

The K-means dilemma with lithology classification.................................................................. 47

Reservoir parameters and implications on reservoir quality .................................................. 47 


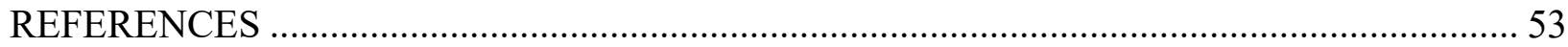

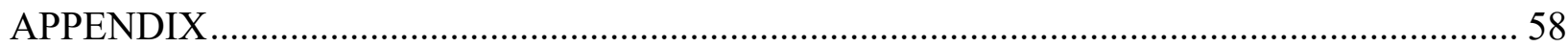

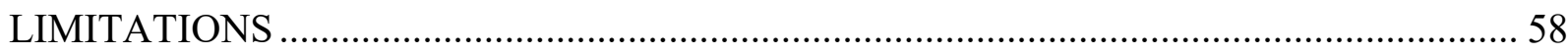

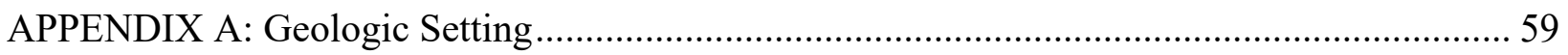

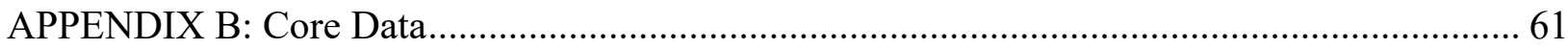

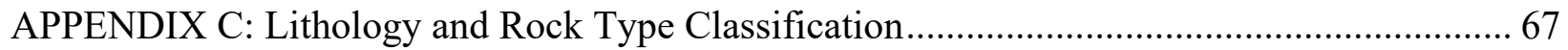

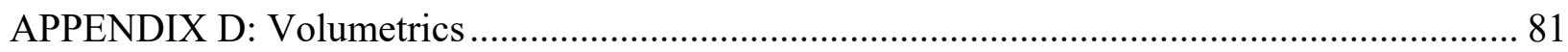

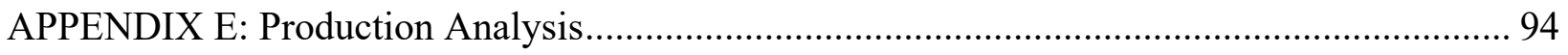




\section{ABSTRACT}

Mississippian Meramec reservoirs of the STACK (Sooner Trend in the Anadarko [Basin] in Canadian and Kingfisher counties) play are comprised of silty limestones, calcareous siltstones, argillaceous-calcareous siltstones, argillaceous siltstones and mudstones. Core-defined reservoir lithologies are directly related to independently derived petrophysical rock types based on core porosity-permeability relationships. Machine-learning classification was employed with core and well-log data to predict lithologies in non-cored wells based on well-log signatures. An Artificial Neural Network produced an overall accuracy of $93 \%$ by charting the model results in a confusion matrix and was applied to a suite of $\operatorname{logs}$ in non-cored wells to generate lithology logs for the Meramec. Using core, wireline well logs and classified lithology logs, the Meramec was divided into eight stratigraphic units characterized as strike-elongate, shoaling-upward parasequences. The bottom three parasequences (lower Meramec) form a retrogradational parasequence set that back-steps to the northwest, with each parasequence capped by a marineflooding surface and the parasequence set capped by a maximum flooding surface. The upper Meramec is characterized by two parasequences that form an aggradational to progradational parasequeunce set followed by two transgressive parasequences in a retrogradational parasequence set.

Lithology, rock type, porosity, permeability, and water saturation models were generated to explore their stratigraphic and lateral variability and to evaluate their relationships to production, pore volume, and hydrocarbon pore volume. Calcareous-rich lithologies and rock types commonly exhibit lower values of porosity and permeability with higher water saturation. Argillaceous-rich lithologies and rock types have relatively higher porosity and permeability with lower water saturation. Examining the spatial distribution of reservoir properties within the 
stratigraphic framework, reservoir quality improves moving up in the retrogradational parasequence set then worsens in the overlying progradational parasequence set. The ideal reservoir quality lies in the parasequences below and above the maximum flooding surface where more argillaceous-rich lithologies and rock types exist, resulting in optimal petrophysical properties, higher pore volume and hydrocarbon pore volume. 


\section{INTRODUCTION}

Mississippian reservoirs in the Anadarko Basin consist of carbonate and siliciclastic deposits with significant petrophysical-property heterogeneity that resulted from uplift and exposure, burial, relative sea-level changes, and diagenesis (e.g., Rogers, 2001; Watney et al., 2001; Mazzullo et al., 2010). Mississippian carbonate and chert-rich reservoirs in southern Kansas and northern Oklahoma, informally known as the "Mississippi Lime", have been the focus of several studies that address their depositional setting and reservoir characteristics (e.g., Peeler, 1985; Parham and Northcutt, 1993; Watney et al., 2001; Mazzullo, 2011; Grammer et al., 2013; LeBlanc, 2014; Flinton, 2016; Mazzullo et al., 2016; Lindzey et al., 2017; Turnini et al., 2017; Price and Grammer, 2018). The basinward and, in part, laterally equivalent deposits of the STACK (Sooner Trend of the Anadarko [Basin] in Canadian and Kingfisher counties) play in central Oklahoma consist of mixed carbonate and siliciclastic sandstones, siltstones, and claystones (Price et al., 2017; Drummond, 2018; Duarte, 2018; Hardwick, 2018; Hickman, 2018;

Leavitt, 2018; Miller, 2018) (Figure 1). In addition to the Late Devonian to Early Mississippian Woodford Shale, the Mississippian Meramec of the STACK play forms significant petroleum reservoirs.

Unlike the "Mississippi Lime", fewer studies document the lithologies, stratigraphy, depositional setting, and stratigraphic variability of Meramec reservoir properties in the STACK area. Examining core and well data, Price et al. (2017) observed that the Mississippian Meramec is primarily a siliciclastic system composed of argillaceous to calcareous siltstones and very fine sandstones and concluded that reservoir quality is inversely related to the amount of calcite cement. Price et al. (2017) interpreted several stacked, low-angle $\left(<1^{\circ}\right)$ prograding clinoforms that have strike-elongate continuity in a northeast-southwest orientation and concluded that 


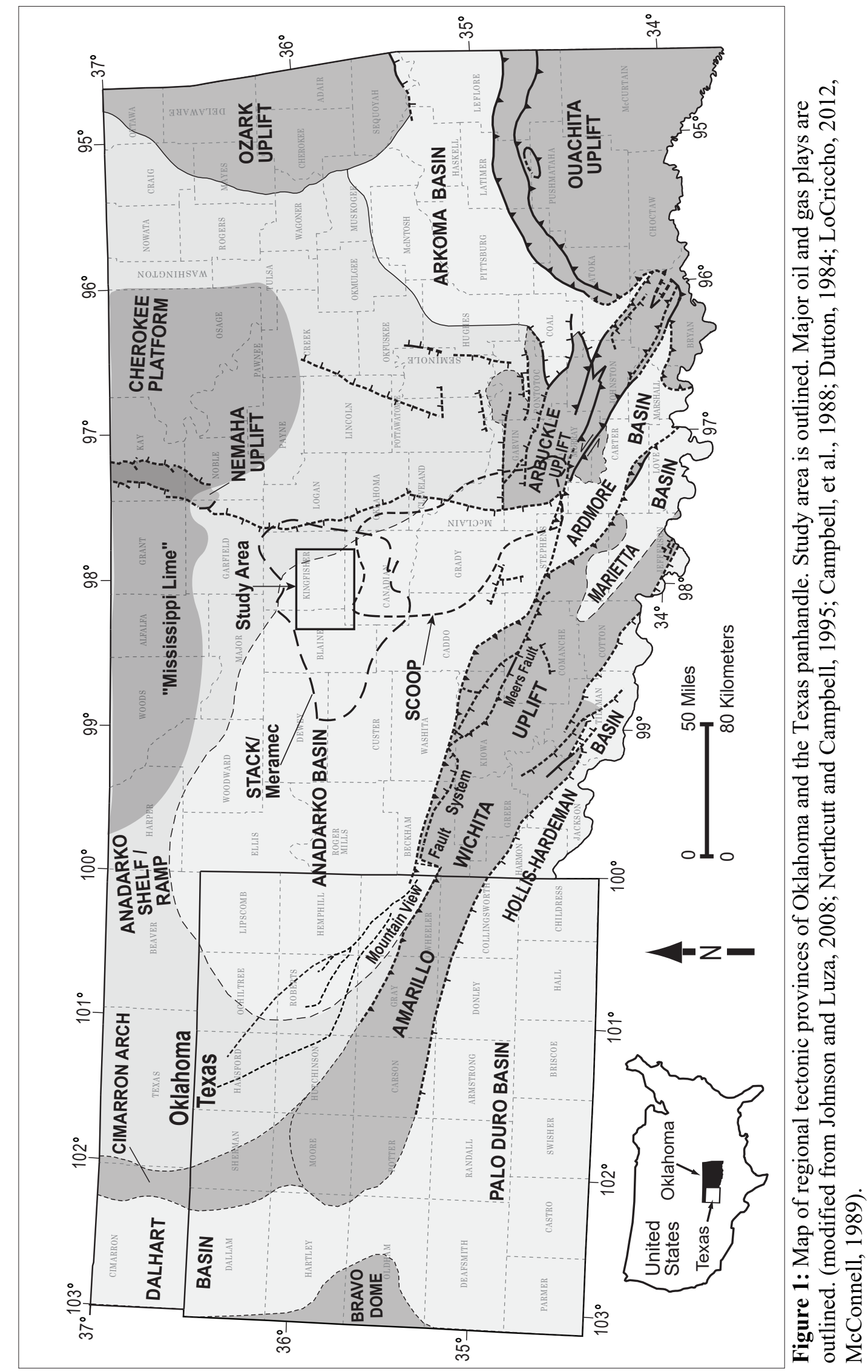


relative changes in sea-level imparted a strong control on the distribution of reservoir-quality facies. They suggest that the Meramec was deposited during an overall rise in sea level and several stacked shallowing-upward parasequences exist that grade upward from more argillaceous into calcareous siltstones. Hardwick (2018) interpreted a mixed carbonatesiliciclastic system for the lower Meramec. Hardwick (2018) found that pervasive marine calcite cement in silt-dominated facies of the Meramec significantly occluded primary porosity and creates baffles for vertical fluid flow while clay partially preserved primary porosity and enhanced fluid flow. Drummond (2018), Hickman (2018), and Miller (2018) also identified mixed carbonate-siliciclastic lithofacies from core in the Meramec and found that the Meramec consists of shallowing upward cycles, commonly capped by marine-flooding surfaces.

Drummond (2018) and Hickman (2018) used machine learning techniques to classify lithologies in non-cored wells based upon unique well-log signatures. Subsequently, they used threedimensional models to relate facies and petrophysical properties to stratigraphy. Hickman (2018) examined how interpreted reservoir parameters affected reservoir quality and how they correlate with Meramec production performance. He found that production was not strongly controlled by lithology throughout his study area, rather completion techniques, reservoir pressure and fluid properties controlled production.

To expand upon previous work, this study investigates the lithologies and rock types of the Mississippian Meramec and how they relate to well-log response. Machine-learning techniques are explored to classify lithologies and rock types in non-cored wells. This study examines the stratigraphic and lateral variability of lithologies, rock types, porosity, permeability and water saturation and evaluates how they relate to production and affect pore volume and hydrocarbon pore volume distribution. 
The study area is in southern Kingfisher, northern Canadian and eastern Blaine counties, Oklahoma (Figure 2). Data include well logs from 1155 wells with an average well spacing of 1300 to $1800 \mathrm{ft}$ (396 to $548 \mathrm{~m}$ ), 104 wells with production data, core data and descriptions (porosity and permeability) from 3 wells (Appendix-B3) in Kingfisher County, x-ray diffraction (XRD) data, $\mathrm{X}$-ray fluorescence (XRF) data, thin-section photomicrographs, and SEM data. In this paper, I begin with an overview of the geologic setting and methodology. Data are used to describe and interpret lithologies and lithofacies in cored wells and classify lithologies in noncored wells using machine-learning techniques. A stratigraphic framework is developed based on interpreted lithological cycles. Three-dimensional reservoir models are generated to map the spatial distribution of lithologies and petrophysical properties and to assess hydrocarbon pore volume. I conclude with a summary of my findings and discuss the stratigraphic controls on pore-volume and hydrocarbon pore-volume distribution.

\section{GEOLOGIC SETTING}

In the late Proterozoic to early Cambrian, the Southern Oklahoma Aulacogen was formed by inferred rifts or failed arms of triple junctions that extended into the North American craton during the formation of the proto-Atlantic Ocean (Burke and Dewey, 1973; Wickham, 1978; Perry, 1990). Once rifting ended in the early Cambrian, the Southern Oklahoma Aulacogen cooled and initiated subsidence, radiating northward giving way to the southern Oklahoma trough (Perry, 1990; Ham et al., 1965). From the Cambrian to the early Mississippian, the subsidence rate decreased over time and a passive continental margin existed outward from the trough (Perry, 1990). 


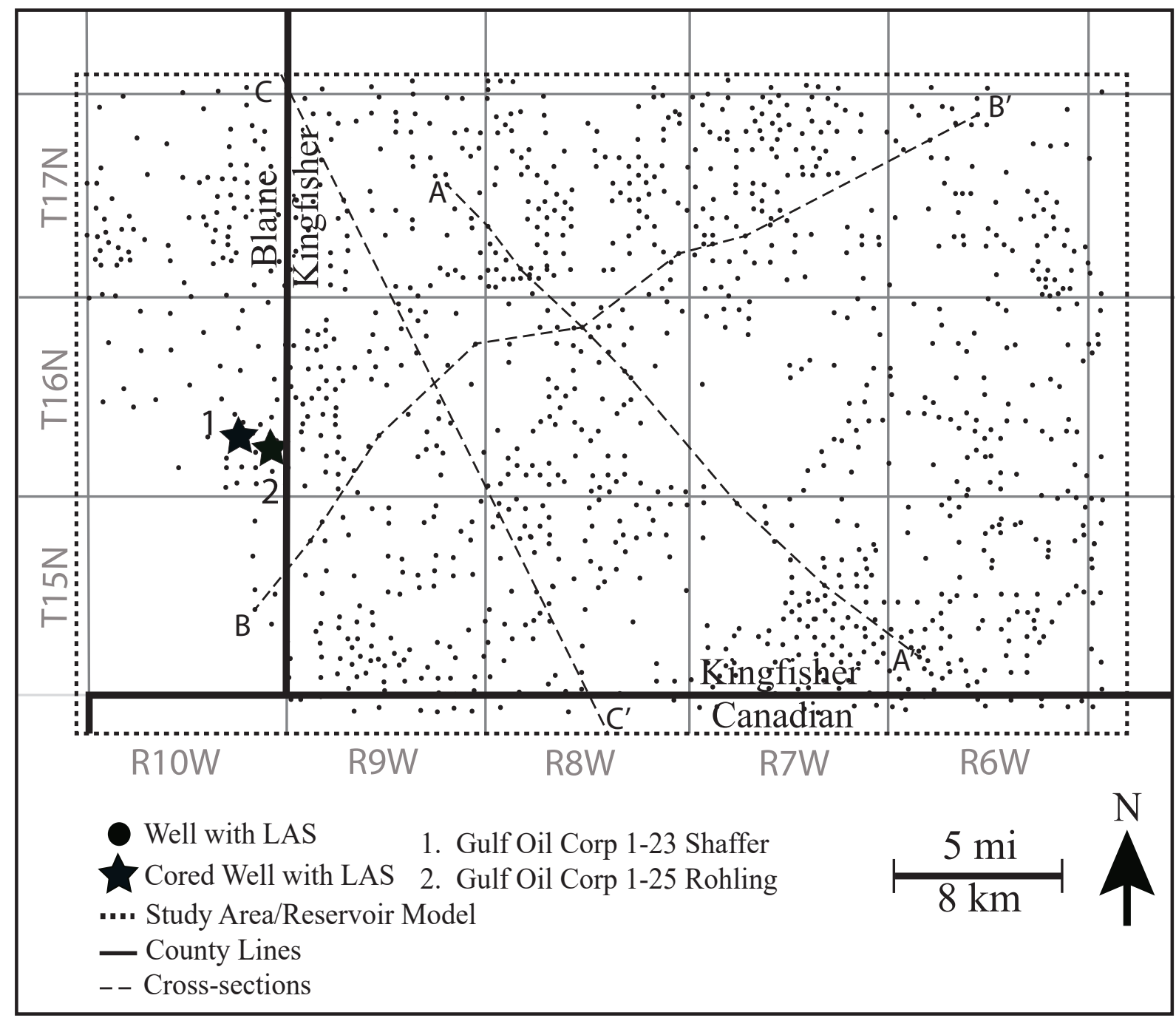

Figure 2: Detailed map of the study area showing locations of 1155 wells with wireline logs (GR, NPHI, RhoB, PE, RILD), 2 cored wells and 3 cross-sections. 
Three major tectonic events shaped the paleogeography of the North American craton during the Mississippian: the Acadian, Antler, and proto-Ouchita orogenies (Gutshick and Sandberg, 1983). These events formed the Transcontinental Arch which cut across North America, trending northeast to southwest and separating the Madison ramp to the northwest and the Burlington ramp to the southeast (Appendix-A1). From the late Mississippian through the early Pennsylvanian, the North American craton collided with Gondwana, giving rise to the Ouachita and Wichita orogenic events, with the orogenic events lasting into the Permian (Ball et al., 1991). As the two plates converged, what is now present-day Texas was pushed northward against the midcontinent, causing the Wichita Mountains and Amarillo Arch to be uplifted and thrust over the southern margins of the southern Oklahoma aulacogen and trough. This initiated subsidence and formed the Anadarko Basin (Ball et al., 1991).

The Anadarko Basin is an asymmetrical foreland basin with a northwest trend that covers approximately $58,000 \mathrm{mi}^{2}\left(150,000 \mathrm{~km}^{2}\right)$ across western Oklahoma, the northern part of the Texas Panhandle, southwestern Kansas, and southeastern Colorado (Beebe, 1959; Lane and De Keyser, 1980; Gutschick and Sandberg, 1983; Ball et al., 1991). At its deepest point, the Anadarko Basin contains up to $40,000 \mathrm{ft}(12,000 \mathrm{~m})$ of Paleozoic sedimentary deposits (Ham et al., 1965). The Anadarko Basin is bound by the Arbuckle uplift to the south, the AmarilloWichita uplift to the southwest, the Nemaha uplift to the east and gradually thins northward into the Hugoton Embayment and Las Animas Arch and the Central Kansas Uplift (Beebe, 1959; Adler, 1971; Lane and De Keyser, 1980; Perry, 1990; Ball et al., 1991).

In the Mississippian, the study area was likely located in the tropical to subtropical latitudinal belt (Appendix-A1), between $20^{\circ} \mathrm{S}$ and $30^{\circ} \mathrm{S}$ relative to the paleoequator (Curtis and 
Champlin, 1959; Witzke, 1990; Mazzulo et al., 2010). Mississippian deposits were the product of broad epeirogenic movement of warm, shallow sea water that occurred throughout the southern midcontinent (Northcutt et al., 2001). Deposition of these sediments within the Anadarko Basin occurred along a low relief ramp $\left(<1^{\circ}\right)$, distally steepening into the basin. The Mississippian marks the transitional period from greenhouse conditions during the earlier Devonian to icehouse conditions in the late Pennsylvanian- early Permian. Read (1995) and Haq and Schutter (2008) suggest that the early Mississippian deposits were a result of lower amplitude sea-level fluctuations characterized by greenhouse conditions while the upper Mississippian deposits consist of higher amplitude sea-level changes indicative of an icehouse climate (Appendix-A2).

Mississippian deposits have been divided into four depositional episodes of Kinderhookian, Osagean, Meramecian, and Chesterian age (Northcutt et al., 2001). The Mississippian interval is described by Sloss (1963) as a $2^{\text {nd }}$-order transgressive-regressive cycle affiliated with the top of the Kaskaskia sequence. It is bounded below by a minor disconformity and above by a major unconformity (Comer, 1991) with several higher-order, transgressiveregressive cycles.

\section{METHODS}

\section{Lithologies, lithofacies, and rock types}

Lithologies and lithofacies were identified in the Mississippian Meramec by combining 1) detailed core descriptions with 2) petrographic data, and 3) calculated mineralogy from X-ray fluorescence. The three cored wells within the study area include Well A (485 ft [148 m]) in an undisclosed location, the Gulf Oil Corp 1-23 Shaffer (242 ft [74 m]) and the Gulf Oil Corp 1-25 Rohling (207 ft [63 m]). Well A (Appendix-B1) was described to identify lithologies and 
lithofacies through observations of composition, sedimentary structures, grain size, color, and diagenetic textures. Core descriptions for the Gulf Oil Corp 1-23 Shaffer and Gulf Oil Corp 1-25 Rohling were incorporated from previous studies (Miller, 2018; Drummond, 2018; Hickman, 2018). Utilizing cored interval gamma-ray logs, a depth correction was applied to each core: +25 $\mathrm{ft}(7.6 \mathrm{~m})$ for Well A, $+5 \mathrm{ft}(1.5 \mathrm{~m})$ for the Gulf Oil Corp 1-23 Shaffer and $+10 \mathrm{ft}(3 \mathrm{~m})$ for the Gulf Oil Corp 1-25 Rohling. Petrographic data including percentages of primary minerals (D. Larese, 2018, personal communication) based on 33 thin sections from the Well A core were used to understand diagenetic processes and products. Additionally, twelve and fourteen thinsection photomicrographs from the Gulf Oil Corp 1-25 Rohling and Gulf Oil Corp 1-23 Shaffer, respectively, were also used to interpret lithologies. For the three cored wells, X-ray fluorescence (XRF) data and calculated mineralogies (from the XRF data) were converted to a well-log format and used to determine the variability of carbonate (calcite + dolomite), clay, and quartz (wt. \%) within the cores to better define lithologies. The XRF inversion algorithm uses major elemental data (e.g., calcium, silicon, magnesium and potassium) and converts it into corresponding mineralogies based on input parameters (e.g., feldspar to clay ratio, siderite to chlorite ratio) set in the algorithm (H. Han and S. Dang, 2018, personal communication). The inversion is calibrated by comparing the calculated mineralogy to measured mineralogy from Fouriertransform infrared spectroscopy (FTIR).

Petrophysically defined rock types and rock-type logs were provided that are based on core-derived porosity and permeability from Well A, Gulf Oil Corp 1-23 Shaffer, Gulf Oil Corp 1-25 Rohling, and Payrock Energy 1506 McCarthy (I. Gupta, 2018, personal communication). Rock types are defined from cross plots of core-measured permeability (air) and porosity and applying Flow Zone Indicator (FZI) cutoffs (Appendix-B2) to separate the data. An FZI cutoff is 
a value that is determined by the ratio of the Reservoir Quality Index (RQI) and the pore-to-grain volume $\left(\mathrm{R}_{\mathrm{pvgv}}\right)$ and is determined by the following equations developed by Amaefule et al. (1993):

$$
\begin{gathered}
R Q I=0.0314 * \sqrt{\frac{k}{\varnothing}} \\
R_{\text {pvgv }}=\frac{\emptyset}{1-\varnothing} \\
F Z I=\frac{R Q I}{R_{\text {pvgv }}}
\end{gathered}
$$

where:

$$
\begin{gathered}
k=\text { permeability } \\
\varnothing=\text { porosity } \\
\mathrm{R}_{\text {pvgv }}=\text { pore-to-grain volume ratio } \\
\mathrm{RQI}=\text { Reservoir Quality Index } \\
\text { FZI }=\text { Flow Zone Indicator }
\end{gathered}
$$

Final FZI cutoff values were determined through a "hit and trial" method. After determining initial FZI cutoff values, geomechanical, mineralogical and petrophysical properties were analyzed by rock types and adjusted accordingly until sufficient contrast of rock types was reached.

\section{Classification of Lithologies}

Electrofacies classification is a method to estimate subsurface properties (e.g. lithology, rock type) in non-cored wells within an area of interest utilizing some form of machine learning. According to Serra and Abbot (1982), "the electrofacies concept is primarily a method of 
describing rock in terms of its well-log characteristics." By comparing a well-log signature to its corresponding cored interval, a relationship can be identified between well-log response and the described facies or calculated rock type from core. This relationship can be used to classify those facies or rock types in non-cored wells based solely on well-log response. A supervised classification approach (Artificial Neural Network [ANN]) and unsupervised clustering approach (principle component analysis and K-means) of machine learning were used to classify lithologies for Well A and the Gulf Oil Corp 1-23 Shaffer, and Gulf Oil Corp 1-25 Rohling wells and applied to non-cored wells. In addition, an ANN was used to classify rock types in non-cored wells.

ANNs are, in essence, a computer's way of mimicking the biological problem-solving skills of the human brain. By being able to resolve patterns in complex data, it can form relationships in the data and then store those data as experiential knowledge. For lithology classification, the ANN minimizes the error between a target output (e.g. a discrete core-based lithology log) and an estimated or classified output (e.g. the lithology classification) (Kumar and Kishore, 2006). This is completed through an iterative process known as training the ANN. By analyzing input variables (well logs), the ANN internally begins to form relationships between the well-log signatures and the corresponding lithology log (target output) based on coredescribed lithologies. The training is completed by randomly cross-validating a user defined amount of the data (50\%) used to form the relationships with the remaining data used to test the accuracy of the relationships. Three different log suite combinations were explored in training the ANN: 1) Gamma ray (GR), Neutron porosity (NPHI), Bulk density (RhoB), 2) GR, NPHI, RhoB, photoelectric effect (PE), 3) GR. NPHI, RhoB, deep resistivity (RILD). 
Principle component analysis (PCA) and K-means clustering groups data (i.e., well-log responses) into similar categories, which are then classified into, in this case, lithologies. PCA is a data preprocessing step conducted prior to K-means clustering to decrease the dimensionality of the data and to determine the extent of the property variability. This is accomplished by finding the covariance matrix of the mean subtracted data point for each variable, then computing the covariance matrix eigenvectors and eigenvalues. The computed eigenvectors represent the principal components and each successive principle component indicates the direction of decreased anisotropy (Smith, 2002).

$\mathrm{K}$-means is a clustering algorithm that minimizes the sum of squared distances from each point to the centroid within each cluster (Hartigan, 1975; Wagstaff et al., 2001; Kunungo et al., 2002). This is done by first assigning a given $\mathrm{K}$ (the number of clusters), which are randomly distributed throughout the data. If $\mathrm{K}$ can cannot be resolved by core data, then it can be determined through other means, one of which is an elbow plot (Appendix-C5). An elbow plot takes the sum of squares between (cumulative distance of each centroid to the global centroid with increasing $\mathrm{K}$ values) and the sum of squares within (cumulative distance between data points in a cluster and the centroid with increasing values of $\mathrm{K}$ ) and plots them against each other. Where the slope decreases (elbow) in each line is the value of natural clusters within the data set as determined by the elbow plot. The data points are then clustered based on the closest centroid and a recalculation of the centroid position is then conducted to reflect the mean position of the data assigned to that centroid. Through an iterative process, the centroid positions are recalculated, and data points are reassigned until each point mean distance is minimized in reference to its centroid (Hartigan, 1975; Wagstaff et al., 2001; Kunungo et al., 2002). 
To evaluate the accuracy of the ANN and PCA/K-means classifications, the lithology and rock type classifications are compared to the actual core-defined lithologies and rock types using a confusion matrix (Ting, 2011). The confusion matrix is a table that shows instances of the actual class in rows and instances of the predicted class in columns (Kohavi and Provost, 1998; Ting, 2011). Two types of accuracies are measured; overall accuracy and user's accuracy. Overall accuracy is the summation of all the correctly predicted classes divided by the number of classes predicted. This value is important but can overshadow the erroneous predictions of individual classes, which is why user's accuracy is also important. User's accuracy is determined by the number of correctly predicted occurrences of a specific class divided by the total occurrences for that class (Janssen and van der Wel, 1994). Overall and user's accuracies were calculated for both ANN and K-means methods.

\section{Stratigraphy}

The stratigraphy of the Meramec was developed by interpreting lithologies, lithofacies successions, and key surfaces using core $(\mathrm{N}=3)$, classified lithology logs, and conventional well logs (gamma-ray, neutron porosity, bulk density and resistivity) for 1155 wells. Formation tops were interpreted in the 1155 wells to subdivide the Meramec into zones (Figure 3) through means of dip- and strike-oriented cross sections. Isopach and structure-contour maps were generated for each zone to visualize the trends and for quality control of the formation tops.

\section{Lithology, Rock-Type, and Petrophysical-Property Modeling}

A 3-D reservoir model grid was generated with commercial software by using the structure-contour maps that define the reservoir zones. The 3-D grid covers an area of approximately $575 \mathrm{mi}^{2}\left(1490 \mathrm{~km}^{2}\right)$ with aerial cell dimensions of $250 \mathrm{ft} \times 250 \mathrm{ft}(76 \mathrm{~m} \mathrm{x} 76 \mathrm{~m})$ with an approximate cell/layer thickness of $2 \mathrm{ft}(0.6 \mathrm{~m})$. The grid in the $\mathrm{I}, \mathrm{J}$, and $\mathrm{K}$ directions is 


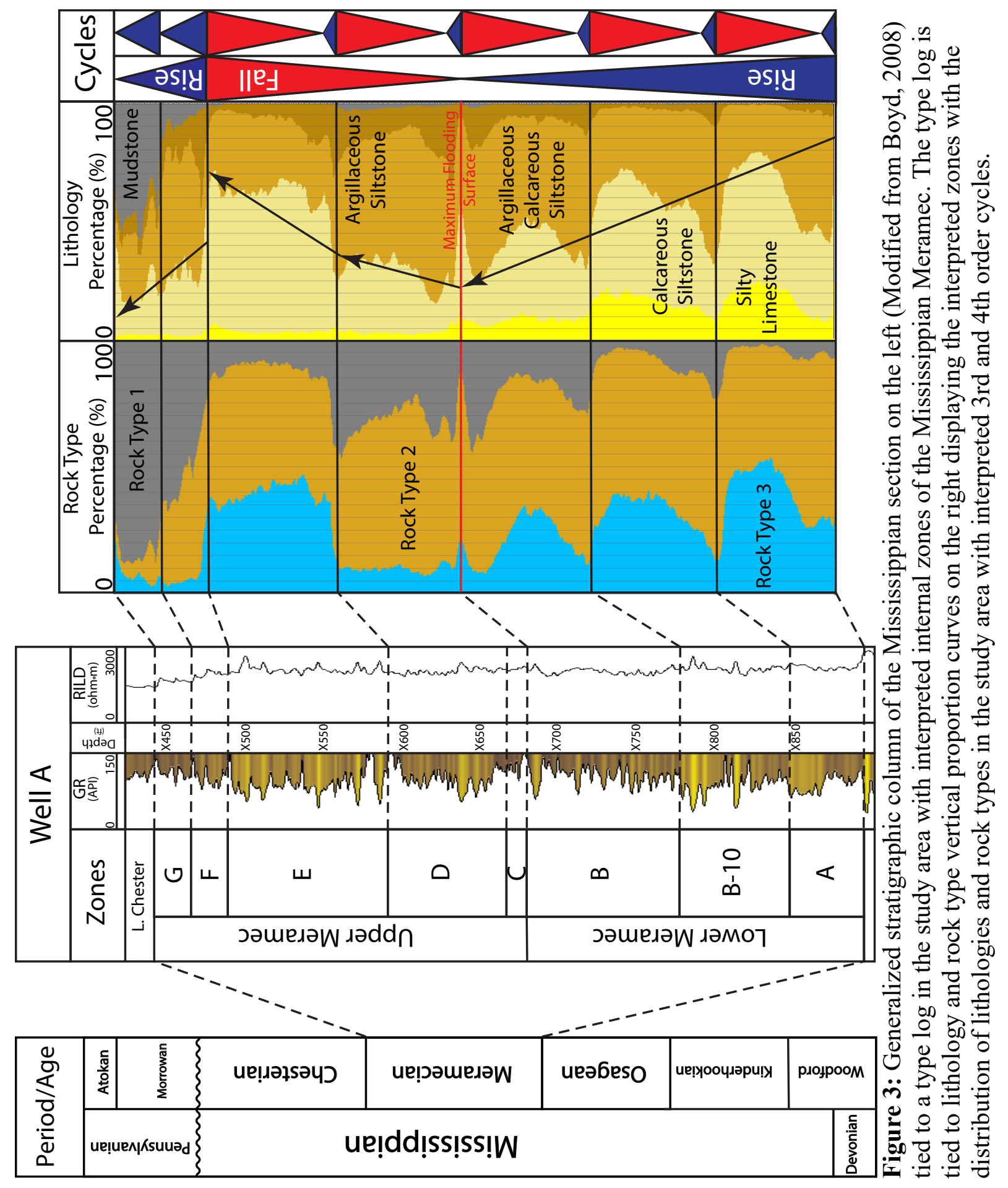


comprised of $406 \times 249 \times 406$ cells, respectively, resulting in 40,677,952 cells. A proportional layering scheme was used. For 4 Upper Meramec zones, the grid was truncated where the zones pinched out.

Vertical lithology variograms were created utilizing both normal and nested spherical variogram models. Horizontal ranges were determined based upon cell size, well spacing, and variogram maps produced from corresponding upscaled logs. Horizontal variogram ranges in both the major and minor directions for the rock-type model were reduced by $500 \mathrm{ft}(152.4 \mathrm{~m})$ and $250 \mathrm{ft}(76.2 \mathrm{~m})$ respectively. The horizontal variograms for the subsequent petrophysical properties were reduced by another $500 \mathrm{ft}(152.4 \mathrm{~m})$ and $250 \mathrm{ft}(76.2 \mathrm{~m})$ in the major and minor directions. Shorter ranges for the major and minor directions aided in capturing smaller scale internal property heterogeneity (e.g. porosity is heterogeneous within lithologies and rock types) (Appendix C-7 to C-10).

To represent the spatial variability of lithologies within the Meramec, a 3-D lithology model was constructed with a commercial software package using sequential-indicator simulation (SIS). The model constraints include: 1) the stratigraphic framework (3-D grid), 2) upscaled lithology logs, 3) variogram parameters by zone, 4) lithology percentages by zone, and 5) lithology proportion volumes for each lithology. Lithology logs were upscaled to the 3-D model grid by assigning a single lithology class to a cell based on the most abundant lithology within a cell. The target fractions of each lithology were obtained from the upscaled lithology logs. The spatial variability of the lithologies was constrained by well-data and lithology proportion volumes. Lithology proportion volumes (Appendix-C10) were generated by first dividing the model area into 8 smaller areas and creating lithology vertical proportion curves 
(VPC) or logs $(\mathrm{N}=8)$ for each area. The VPC log data were mapped to generate a proportion volume for each lithology.

A 3-D rock type model was constructed to evaluate the spatial distribution of rock types. Rock types were also modeled using SIS with the following modeling constraints: 1) the stratigraphic framework (3-D grid), 2) upscaled rock-type logs, 3) variogram parameters by zone, 4) rock-type percentages by zone, and 5) rock-type proportion volumes for each rock type. Rock-type logs were upscaled to the 3-D model grid by assigning a single rock type to a cell based on the most abundant rock type within a cell. Target fractions of each rock type were obtained from the upscaled rock-type logs. The spatial variability of the rock types was constrained by rock type proportion volumes (Appendix-C11) generated from vertical rock-type proportion curves $(\mathrm{N}=8)$ using a similar method as described earlier for lithologies.

A 3-D porosity model was generated to evaluate the distribution of total porosity (PHITot) within the study area. $\mathrm{PHI}_{\mathrm{Tot}}$ logs were biased to the rock-type logs and upscaled using an arithmetic mean. The porosity model was generated using a sequential-Gaussian simulation (SGS) and was constrained to: 1) 3-D rock-type model, 2) upscaled PHITot logs (biased to rock type), 3) porosity histograms by zone and rock type, and 4) variogram parameters by zone and rock type. A permeability $(k)$ model was calculated using the FZI equation with inputs from the $\mathrm{PHI}_{\mathrm{Tot}}$ and rock-type models.

Water saturation $\left(S_{w}\right)$ logs were calculated using the basic Archie equation, resistivity (RILD) logs, and PHITot logs. The parameters for the Archie equation were determined through core and lab measurements (Ali Tinni, 2019, personal communication) where: Cementation exponent $(m)=1.73$, Formation water resistivity $\left(R_{w}\right)=0.026 \mathrm{Ohm} \bullet \mathrm{m}$, and Saturation exponent (n) was determined to be a function of porosity: 


$$
S_{w}=\left(\frac{R_{w}}{\varphi^{m} R_{t}}\right)^{\frac{1}{n}}
$$

A 3-D $S_{w}$ model was generated using SGS and constrained to: 1) the 3-D rock type model, 2) upscaled $S_{w} \operatorname{logs}$ (biased to rock type), $S_{w}$ histograms by zone and rock type, and variogram parameters by zone and rock type.

\section{Volumetric and Production Analysis}

The 3-D rock type, PHITot and $S_{w}$ models were used in a volumetric uncertainty analysis workflow (Figure 4) to calculate low, middle, and high case scenarios for pore volume and hydrocarbon pore volume (HCPV). The volumetric calculation was completed through an uncertainty analysis conducted in commercial software with 25 realizations of pore volume and hydrocarbon pore volume. For this analysis, the global seed value for the rock type model was randomized to generate the different realizations. Each rock-type realization was then used as a constraint for associated PHITot and $S_{w}$ models. For the 25 realizations, P10 (most conservative), P50 and P90 (most optimistic) values for pore volume were determined and related to their corresponding rock type, $\mathrm{PHI}$ Tot, and $S_{w}$ models (Appendix-D1 to D4) for analysis. HCPV was calculated by simply multiplying pore volume by oil saturation $\left(1-S_{w}\right)$. PHITot was used for volumetric calculations due to the possibility that hydrocarbons in the Meramec exist in clay-rich lithologies. Average maps were generated for the entire Meramec and by zone to evaluate the spatial distribution of pore volume and HCPV.

Meramec horizontal wells with production data $(\mathrm{N}=104)$ were categorized by reservoir zone. Synthetic logs were extracted from the generated 3-D models along the laterals for lithology, rock type, porosity, permeability, and water saturation. Completion data including 


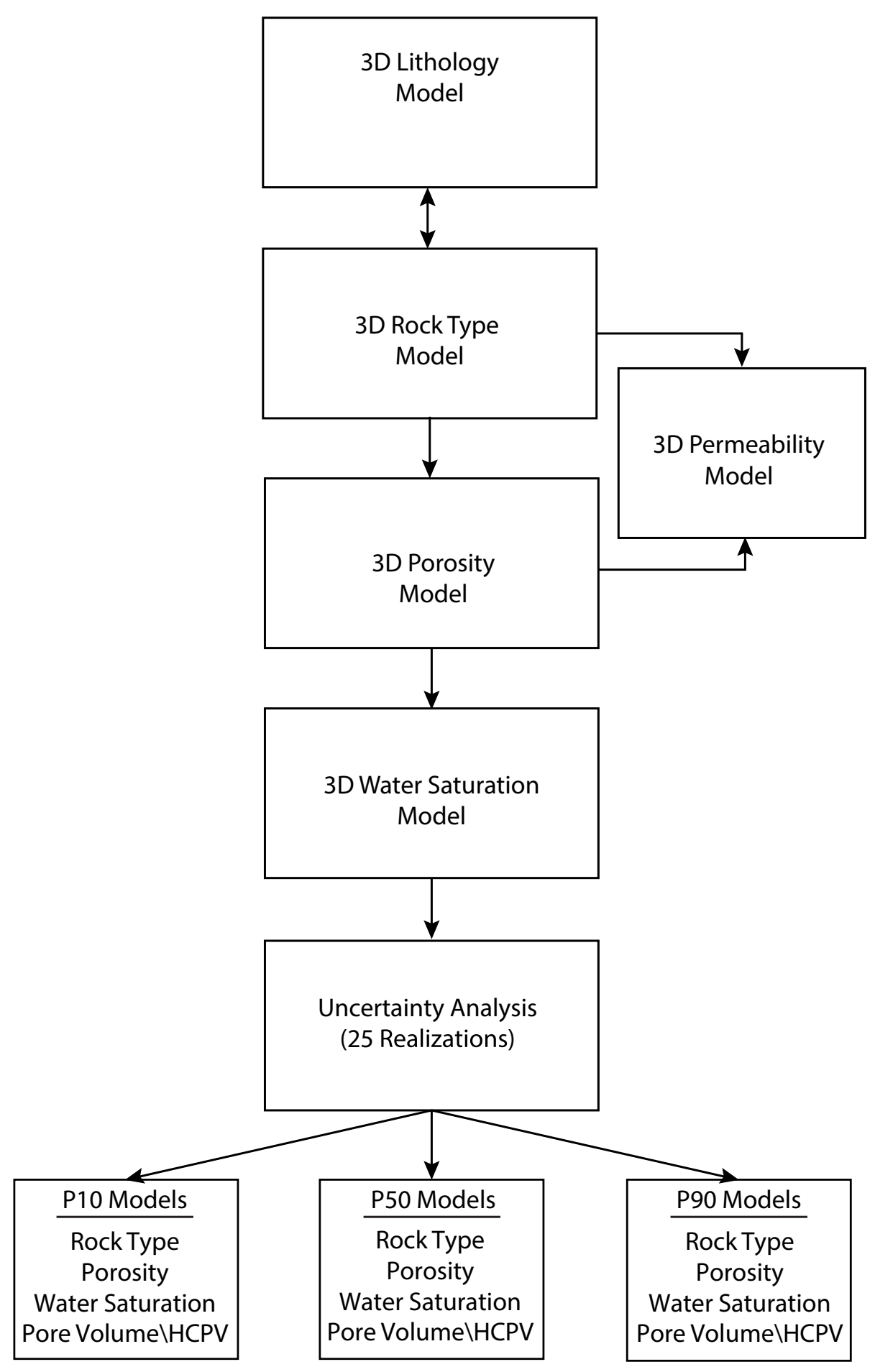

Figure 4: Generalized model workflow outlining the steps taken to generate the 3-D models for the study area and the subsequent volumetric analysis 
average stage length and average amount of stages in the lateral were also considered parameters. Production data for 180-day cumulative oil production were chosen for analysis. The production data were normalized by dividing the 180-day cumulative production values by the lateral length of the well, normalizing the data into BBL/ft. For lithology and rock type logs, ratios were calculated to determine the fraction of that lithology and rock type present in the lateral. Averages were calculated for porosity, permeability, and water saturation along the lateral. These values for the 104 wells were then cross-plotted against 180-day cumulative oil production (STB) normalized to BBL/ft to observe the correlation between reservoir parameters and production.

\section{RESULTS}

\section{Lithologies, lithofacies, and rock types}

The Mississippian Meramec in the STACK area consists primarily of 5 lithologies: 1) mudstone, 2) argillaceous siltstone, 3) argillaceous-calcareous siltstone, 4) calcareous siltstone and 5) silty limestone; and 8 lithofacies: 1) structureless mudstone, 2) silty laminated mudstone, 3) silty bioturbated mudstone, 4) calcareous bioturbated siltstone, 5) calcareous laminated siltstone, 6) very fine grained calcareous structureless sandstone to very course siltstone, 7) very fine grained calcareous, cross-stratified sandstone to very course siltstone, and 8) skeletal silty packstone to grainstone (Figures 5 and 6, Table 1). Lithofacies gradually vary stratigraphically and commonly do not have distinct boundaries. Given that several lithofacies qualitatively exhibit similar well-log responses, lithologies were estimated in non-cored wells using machine learning.

Three rock types $(1,2$, and 3 ) are defined based on the FZI approach (Gupta, 2018, personal communication). Of the three rock types, rock type 1 has the least carbonate (13 wt. $\%$ of calcite 

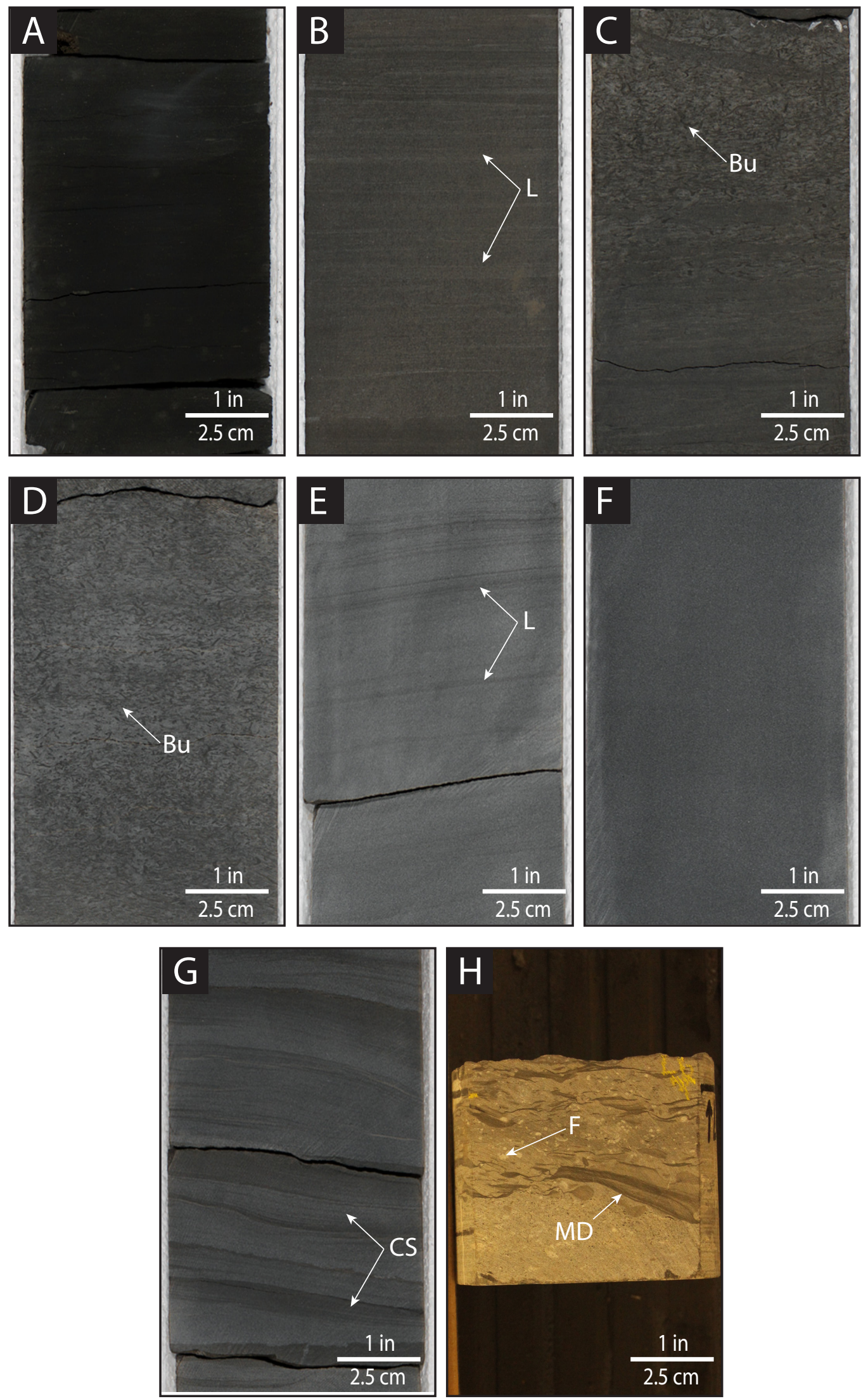
Figure 5: Core photographs of the identified Meramec lithofacies in the study area: A) Structureless mudstone (Well A (X419 ft [X871 m] MD). B) Silty laminated mudstone (Well A (X423 ft [X872 m] MD). C) Silty bioturbated mudstone (Well A (X429.5 ft [X874 m] MD). D) Calcareous bioturbated siltstone (Well A (X718 ft [X962 m] MD). E) Calcareous laminated siltstone (Well A (X523 ft [X903m] MD). F) Calcareous structureless very fine-grained sandstone/ very course siltstone (Well A (X535 ft [X906 m] MD). G) Calcareous, crossstratified very fine-grained sandstone/very course siltstone (Well A (X537 ft X907 m] MD). H) Skeletal silty packstone to grainstone Gulf Oil Corp 1-23 Shaffer (9696 ft [2955 m] MD). Legend: $\mathrm{L}=$ laminations, $\mathrm{Bu}=$ bioturbations, $\mathrm{CS}=$ crossstratification, $\mathrm{MD}=$ Mud Drape, $\mathrm{F}=$ Fossil. 

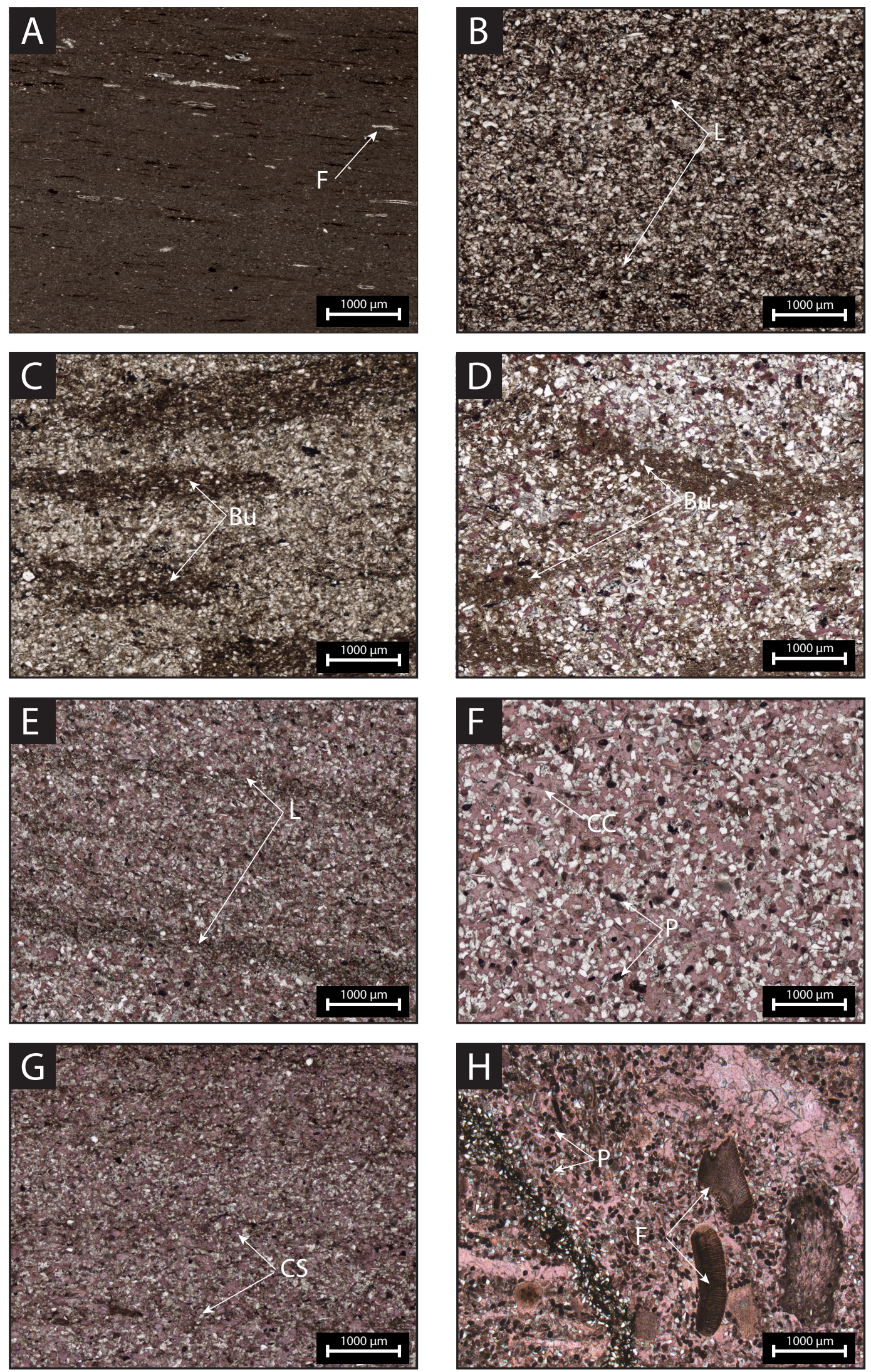
Figure 6: Thin section photomicrographs of the identified Meramec lithofacies in the study area: A) Structureless mudstone. Very clay rich with dispersed fossil fragments and pyrite. (Well A (X418.15ft [X871 m] MD). B) Silty laminated mudstone. Angular to sub-angular, moderately-well sorted silt-sized quartz grains. Clay rich with faint planar to inclined lamina. Dispersed peloids, pyrite and calcitelfossil fragments present. (Well A (X424 ft [X872 m] MD). C) Silty bioturbated mudstone. Angular to sub-angular, moderately well sorted silt-sized quartz grains. Clay rich with burrows comprising of more clay material. Peloids, dispersed pyrite and calcitelfossil fragments present (Well A (X430 ft [X874 m] MD). D) Calcareous bioturbated siltstone. Angular to sub-angular, moderately well sorted silt-sized quartz grains. Higher amounts of calcite present with clay-filled burrows and intergranular clay material (Well A (X718.20 ft [X962 m] MD). E) Calcareous laminated siltstone. Elevated levels of calcite. Angular to sub-angular, well sorted silt-sized quartz grains. Planar to inclined, clay-rich laminations. (Well A (X523 ft [X903m] MD). F) Calcareous structureless very fine-grained sandstone/ very course siltstone. Angular very coarse-grained silt to very-fine grained sand, quartz grains. Heavily cemented with calcite. Fossil fragments and calcite grains prevalent. Dispersed peloids observed (Well A (X535 ft [X906 m] MD). G) Calcareous, cross-stratified very fine-grained sandstone/very course siltstone. Angular very coarse-grained silt to very-fine grained sand, quartz grains. Heavily cemented with calcite. Fossil fragments and calcite grains prevalent. Planar, wavy and inclined laminations observed with elevated clay minerals. Dispersed peloids and pyrite found. (Well A (X537 ft X907 m] MD). H) Skeletal silty packstone to grainstone. Fossil fragments prevalent with high levels of calcite cement and grains. Peloids and silt-sized quartz grains found throughout. (Gulf Oil Corp 1-23 Shaffer (9696.25 ft [2955 m] MD). Legend: $\mathrm{L}=$ laminations, $\mathrm{Bu}=$ bioturbations, $\mathrm{CS}=$ cross-stratification, $\mathrm{F}=$ Fossil, $\mathrm{P}=$ peloid. 


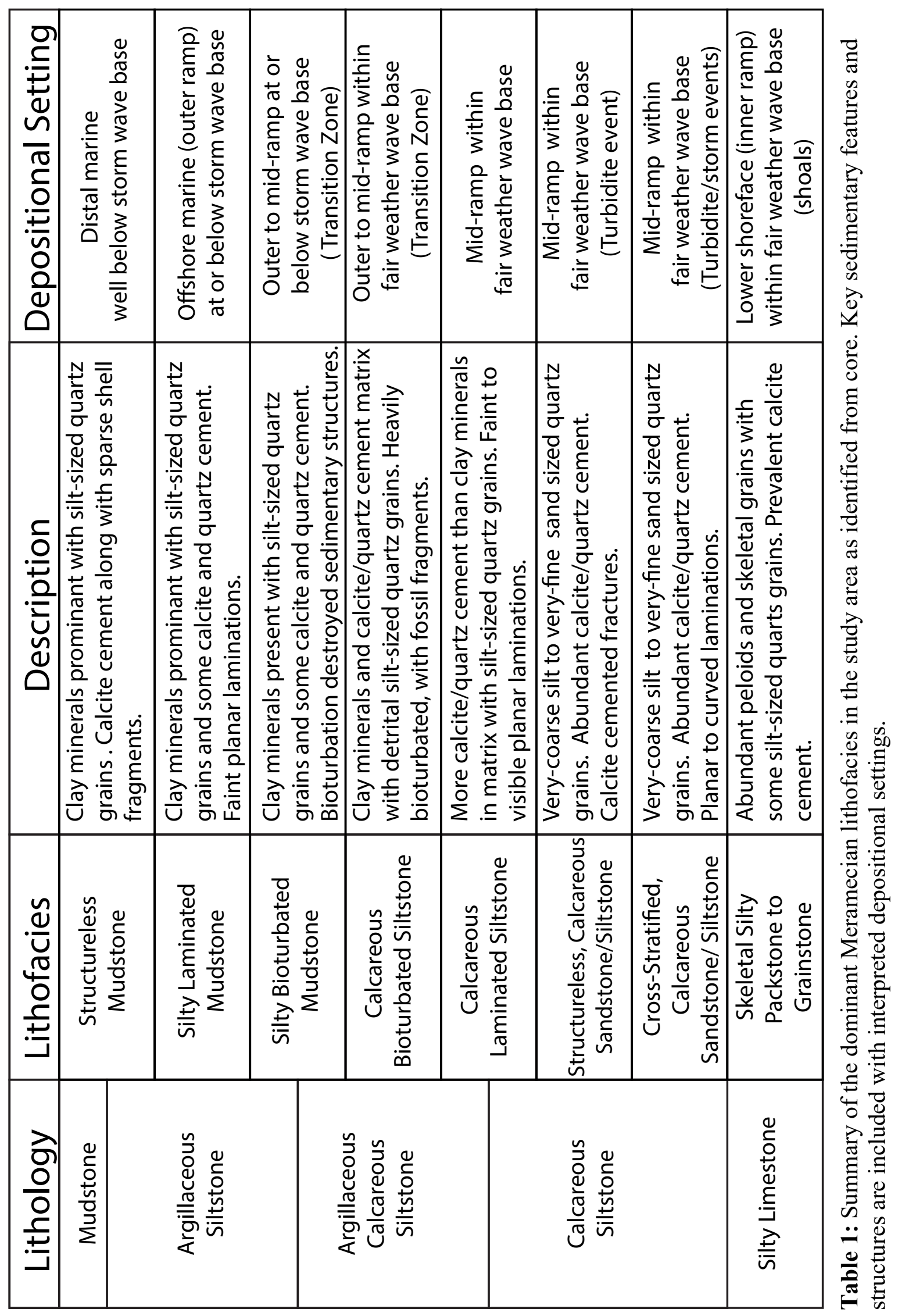


+ dolomite), the most clay (27 wt. \%) and has the lowest Young's Modulus (41 GPa). Compared to the other rock types, rock type 1 is the most porous (5.8 vol\%) and exhibits lower water saturation (33\%). In contrast, rock type 3 has the most carbonate (38 wt.\%) and the least clay (14 wt.\%). Rock type 3 exhibits low porosity (2.3\%), high Young's Modulus (53 GPa), and relatively high water saturation (53\%). Rock type 2 has values for these parameters that are between rock types 1 and 3 . When comparing the interpreted lithologies to rock types, there is a direct correlation. Mudstone, argillaceous siltstone, and some argillaceous-calcareous siltstone (more clay-rich end member) relate directly to rock type 1 . The majority of argillaceous-calcareous siltstone correlates to rock type 2 , and calcareous siltstone and silty limestone relate to rock type 3.

\section{Classification of Lithologies}

The primary goal of using machine learning in this study was to classify lithologies in non-cored wells based on well-log data. The complication with lithofacies in the Meramec lies in their unique fine-scale features such as grain size, sedimentary structures and bedding planes. These characteristics are not manifested in distinctive well-log signatures, making them difficult to classify accurately. By grouping lithofacies into their correlative parent lithologies, they are distinguishable by log response, allowing them to be classified more accurately in non-cored wells.

Through evaluation of the target output (core lithology log) and the predicted output (classified lithology log) of the ANN by means of confusion matrices, relatively high overall and user's accuracies were achieved (Figure 7, Table 2, Appendix-C1 and C2). For the Well A core, the overall accuracy is $93 \%$ utilizing a log suite of GR, NPHI, RhoB and PE. User's accuracies are $100 \%, 91.6 \%, 86.7 \%$ and $97.7 \%$ for mudstone, argillaceous siltstone, argillaceous-calcareous 


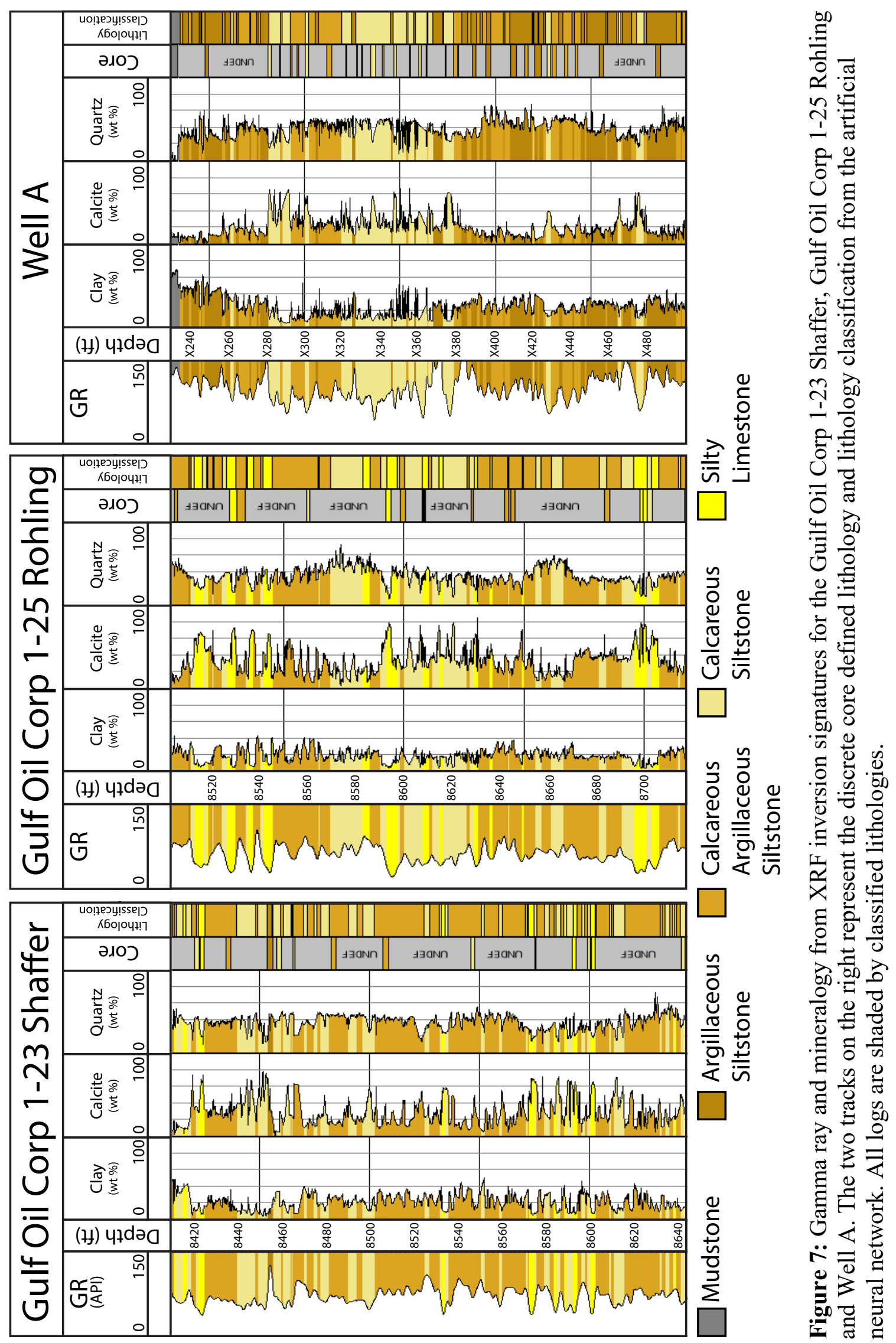




\begin{tabular}{|l|r|r|r|r|}
\hline \multicolumn{1}{|c|}{ ANN } & \multicolumn{4}{|c|}{ GR, NPHI, RhoB, PE } \\
\hline \multicolumn{1}{c|}{ Core } & Mudstone & $\begin{array}{l}\text { Argillaceous } \\
\text { Siltstone }\end{array}$ & $\begin{array}{l}\text { Arg. Calc. } \\
\text { Siltstone }\end{array}$ & $\begin{array}{l}\text { Calcareous } \\
\text { Siltstone }\end{array}$ \\
\hline Mudstone & 25 & 0 & 0 & 0 \\
\hline Argillaceous Siltstone & 0 & 317 & 22 & 4 \\
\hline Arg. Calc. Siltstone & 0 & 28 & 235 & 4 \\
\hline Calcareous Siltstone & 0 & 1 & 14 & 350 \\
\hline User Accuracy & $100.0 \%$ & $91.6 \%$ & $86.7 \%$ & $97.7 \%$ \\
\hline
\end{tabular}

Overall Accuracy : $92.7 \%$

\begin{tabular}{|l|r|r|r|r|}
\hline B ANN & \multicolumn{4}{|c|}{ GR, NPHI, RhoB, PE } \\
\hline \multicolumn{1}{c|}{ Core } & $\begin{array}{c}\text { Argillaceous } \\
\text { Siltstone }\end{array}$ & $\begin{array}{l}\text { Arg. Calc. } \\
\text { Siltstone }\end{array}$ & $\begin{array}{l}\text { Calcareous } \\
\text { Siltstone }\end{array}$ & \multicolumn{1}{c|}{$\begin{array}{l}\text { Silty } \\
\text { Limestone }\end{array}$} \\
\hline Argillaceous Siltstone & 0 & 0 & 0 & 0 \\
\hline Arg. Calc. Siltstone & 0 & 209 & 46 & 0 \\
\hline Calcareous Siltstone & 0 & 26 & 39 & 24 \\
\hline Silty Limestone & 0 & 6 & 7 & 137 \\
\hline User Accuracy & $0.0 \%$ & $86.7 \%$ & $42.4 \%$ & $85.1 \%$ \\
\hline
\end{tabular}

Overall Accuracy : $77.9 \%$

\begin{tabular}{|l|r|r|r|r|}
\hline \multicolumn{1}{|c|}{ ANN } & \multicolumn{4}{|c|}{ GR, NPHI, RhoB, PE } \\
\hline \multicolumn{1}{c|}{ Core } & $\begin{array}{c}\text { Argillaceous } \\
\text { Siltstone }\end{array}$ & $\begin{array}{c}\text { Arg. Calc. } \\
\text { Silstone }\end{array}$ & $\begin{array}{l}\text { Calcareous } \\
\text { Siltstone }\end{array}$ & $\begin{array}{c}\text { Silty } \\
\text { Limestone }\end{array}$ \\
\hline Argillaceous Siltstone & 40 & 4 & 5 & 0 \\
\hline Arg. Calc. Siltstone & 4 & 140 & 0 & 0 \\
\hline Calcareous Siltstone & 5 & 61 & 136 & 7 \\
\hline Silty Limestone & 0 & 0 & 5 & 92 \\
\hline User Accuracy & $81.6 \%$ & $68.3 \%$ & $93.2 \%$ & $92.3 \%$ \\
\hline
\end{tabular}

Overall Accuracy : $84.8 \%$

Table 2: Confusion matrices displaying the accuracies for the artificial neural network in Petrel using a log suite of gamma ray (GR), neutron porosity (NPHI), bulk density (RhoB) and photoelectric effect (PE) for: A) Well A B) Gulf Oil Corp 1-23 Rohling and C) Gulf Oil Corp 1-25 Shaffer. 
siltstone, and calcareous siltstone, respectively. The unsupervised PCA/K-means clustering method yielded lower accuracies (Table 3) utilizing multiple log-suite combinations for Well A. An elbow plot (Appendix-C5) indicates that three clusters are naturally identifiable in the soft data (well $\operatorname{logs}$ ). Due to a lack of additional nearby cored wells to conduct blind tests to further evaluate the accuracy of the ANN classification model, a qualitative method was used. Lithologies were defined for small discrete core intervals (samples) of the Meramec in Well A, Gulf Oil Corp 1-23 Shaffer and Gulf Oil Corp 1-25 Rohling, and those lithology intervals were used to train the ANN. Lithologies were then classified for the other cored intervals of the three wells, using the ANN (cross validation). The results of cross validation were qualitatively evaluated by cross-plotting clay (wt. \%) versus carbonate (calcite + dolomite wt.\%) (mineralogy based on XRF data) and color coding the plot by ANN-derived classified lithologies. (Figure 8). The plot illustrates that the calcareous siltstones and limestones plot with high calcite and low clay, and that mudstones and argillaceous siltstones exhibit high clay and relatively low calcite. Thus, the ANN-classified lithologies are consistent with the XRF-derived mineralogy.

For lithology classification in non-cored wells, the reservoir model was divided into northwest and southeast areas (Appendix-C4) with the boundary between the two areas oriented approximately parallel to depositional strike. The boundary was selected to correspond to a shift in gamma-ray values based on a Meramec gamma-ray map. The Well A ANN model was used to classify lithologies in all non-cored wells represented in the southeast area, whereas the Gulf Oil Corp 1-23 Shaffer and Gulf Oil Corp 1-25 Rohling ANN model was used to classify the northwest area wells. The reservoir model is divided into areas for lithology classification because silty limestone present in the Gulf Oil Corp 1-23 Shaffer and Gulf Oil Corp 1-25 Rohling cores is not present in the Well A core (located south of those wells) and mudstone 


\begin{tabular}{|l|r|r|r|r|}
\hline \multicolumn{1}{c|}{ Kmeans } & \multicolumn{4}{|c|}{ GR, NPHI, RhoB, PE } \\
\hline Core & Mudstone & $\begin{array}{c}\text { Argillaceous } \\
\text { Siltstone }\end{array}$ & $\begin{array}{l}\text { Arg. Calc. } \\
\text { Siltstone }\end{array}$ & $\begin{array}{l}\text { Calcareous } \\
\text { Siltstone }\end{array}$ \\
\hline Mudstone & 25 & 0 & 0 & 0 \\
\hline Argillaceous Siltstone & 126 & 207 & 10 & 0 \\
\hline Arg. Calc. Siltstone & 20 & 175 & 72 & 0 \\
\hline Calcareous Siltstone & 2 & 0 & 151 & 141 \\
\hline User Accuracy & $14.5 \%$ & $54.2 \%$ & $30.9 \%$ & $100.0 \%$ \\
\hline
\end{tabular}

Overall Accuracy : $47.9 \%$

\begin{tabular}{|l|r|r|r|r|}
\hline B Kmeans & \multicolumn{4}{|c|}{ GR, NPHI, RhoB,RILD } \\
\hline \multicolumn{1}{c|}{ Core } & Mudstone & $\begin{array}{l}\text { Argillaceous } \\
\text { Siltstone }\end{array}$ & $\begin{array}{l}\text { Arg. Calc. } \\
\text { Siltstone }\end{array}$ & $\begin{array}{l}\text { Calcareous } \\
\text { Siltstone }\end{array}$ \\
\hline Mudstone & 25 & 0 & 0 & 0 \\
\hline Argillaceous Siltstone & 173 & 123 & 41 & 6 \\
\hline Arg. Calc. Siltstone & 0 & 172 & 61 & 34 \\
\hline Calcareous Siltstone & 2 & 5 & 42 & 245 \\
\hline User Accuracy & $12.5 \%$ & $41.0 \%$ & $42.4 \%$ & $85.9 \%$ \\
\hline
\end{tabular}

Overall Accuracy : $48.9 \%$

\begin{tabular}{|l|r|r|r|r|}
\hline \multicolumn{1}{c|}{ Kmeans } & \multicolumn{4}{|c|}{ GR, NPHI, RhoB } \\
\hline \multicolumn{1}{c|}{ Core } & Mudstone & $\begin{array}{c}\text { Argillaceous } \\
\text { Siltstone }\end{array}$ & $\begin{array}{l}\text { Arg. Calc. } \\
\text { Siltstone }\end{array}$ & $\begin{array}{l}\text { Calcareous } \\
\text { Siltstone }\end{array}$ \\
\hline Mudstone & 25 & 0 & 0 & 0 \\
\hline Argillaceous Siltstone & 173 & 123 & 41 & 6 \\
\hline Arg. Calc. Siltstone & 0 & 168 & 61 & 38 \\
\hline Calcareous Siltstone & 2 & 12 & 24 & 256 \\
\hline User Accuracy & $12.5 \%$ & $40.6 \%$ & $48.4 \%$ & $85.3 \%$ \\
\hline
\end{tabular}

Overall Accuracy: $50.1 \%$

Table 3: Confusion matrix for K-means showing accuracies of the classifications for lithologies in Well A. K-means inputs include: A) gamma ray (GR), neutron porosity (NPHI), bulk density (RhoB) and photoelectric effect (PE), B) gamma ray (GR), neutron porosity (NPHI), bulk density (RhoB) and deep resistivity (RILD) and C) gamma ray (GR), neutron porosity (NPHI) and bulk density (RhoB). 

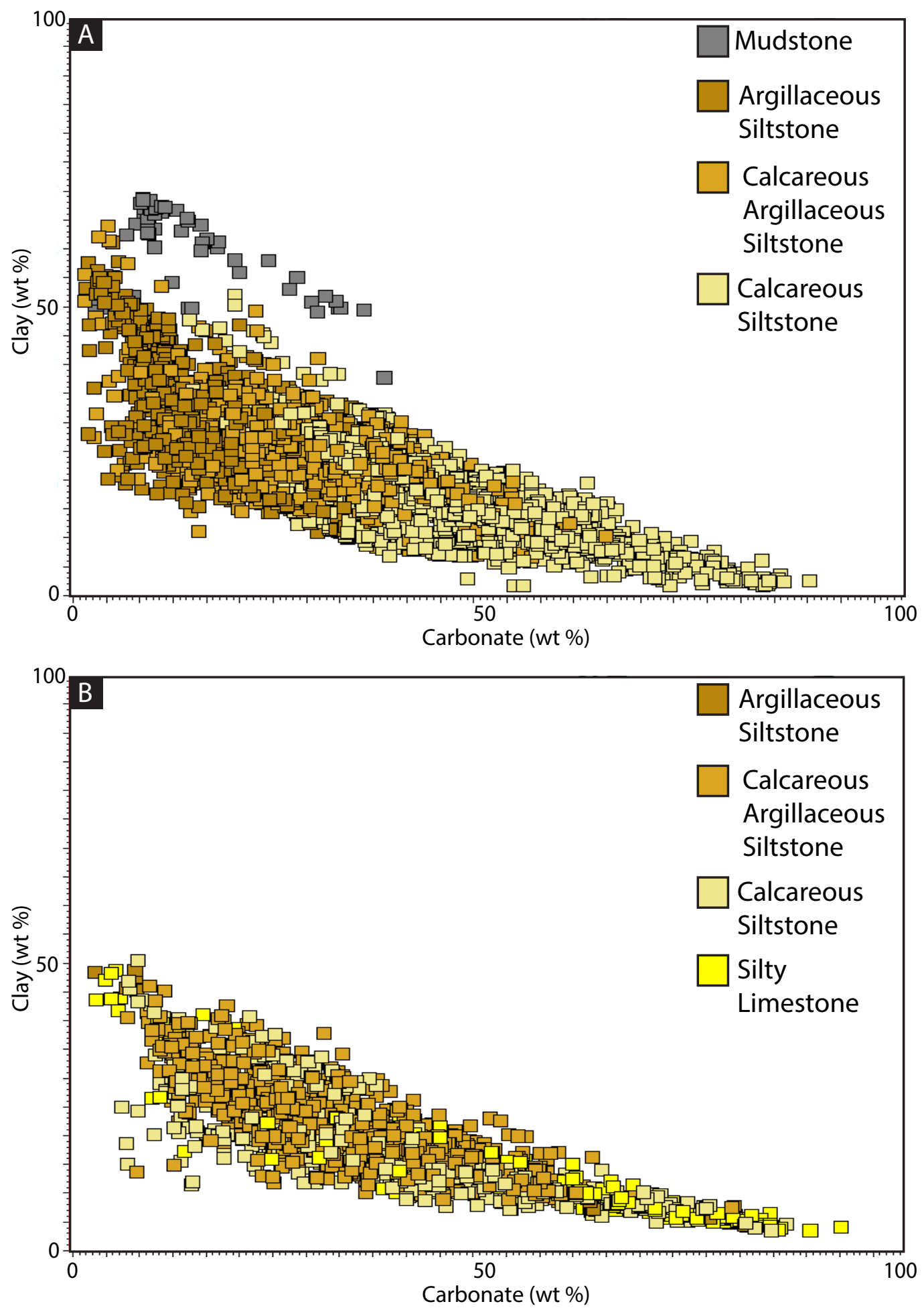

Figure 8: Cross plots of clay and calcite in weight percent colored by the classified lithologies in the corresponding wells. A) represents Well A. B represents both the Gulf Oil Corp 1-23 Shafer and 1-25 Rohling. 
described in Well A is absent in the Gulf Oil Corp 1-23 Shaffer and Gulf Oil Corp 1-25 Rohling. This suggests that a change in depositional characteristics exist and different ANN models are required.

In regard to rock types, due to limited sample sizes from cores in the study area, rock types were classified for the entire study area using an ANN for only the Well A core. The ANN for rock types produced an overall accuracy of $70 \%$ with user's accuracies of $80 \%, 67 \%$ and $66 \%$ for rock types 1, 2 and 3, respectively (Appendix-C3). The same qualitative method used for lithologies was used to evaluate the rock-type classification results. The plot illustrates that the calcareous-rich rock type 3 plots with high calcite and low clay, and that the mudstone-rich rock type 1 exhibits high clay and relatively low calcite. Thus, the ANN-classified rock types are consistent with the XRF-derived mineralogy (Figure 9).

\section{Stratigraphy}

The Meramec in the study area ranges in thickness from $63 \mathrm{ft}(19 \mathrm{~m})$ in the northwest to $525 \mathrm{ft}(160 \mathrm{~m})$ in the southwest (more distal). The Mississippian interval is considered to be a 2nd-order-regressive (5-50 Ma) sequence which represents the upper part of the Kaskaskia Sequence of Sloss (1963). The Mississippian sequence is capped by a major unconformity. Higher-order cyclicity (Figure 3; e.g., third- and fourth-order) is interpreted in the Meramec interval (e.g., Price et al., 2017; Miller, 2018; Drummond, 2018); however, the specific timing of each cycle or order of cyclicity is not known. Milankovich-driven eustasy is the attributed driving force to these shorter, higher-order cycles; however, other controlling factors may also include: rates of sedimentation, short term (seasonal) climate variations, and tectonics (e.g., Read, 1995; Rogers, 2001; Watney et al, 2001). Numerous upward-shallowing depositional cycles are interpreted based on the vertical succession of lithofacies as observed in core and 


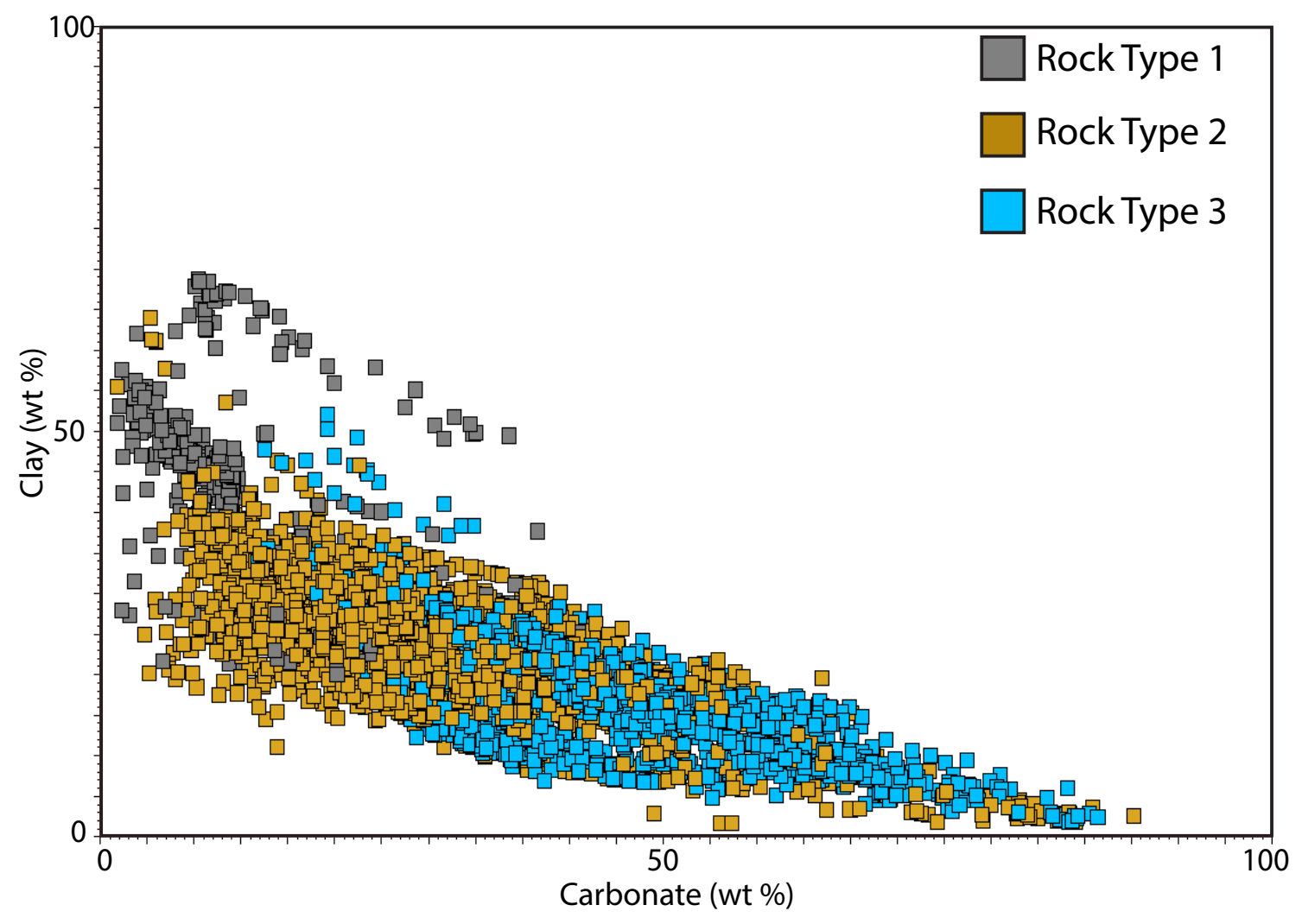

Figure 9: Cross-plot of carbonate (calcite + dolomite) and clay content from the Well A core derived from an $\mathrm{x}$-ray fluorescence (XRF) inversion to mineralogy. The data points are color coded by the classified rock types determined from the artificial neural network. Rock type 1 is clay rich, rock type 2 contains both carbonate and clay and rock type 3 is carbonate rich. 
interpreted from well logs. An idealized stacking pattern is defined as (from base to top) mudstone, argillaceous siltstone, argillaceous calcareous siltstone, and calcareous siltstone/silty limestone. Each upward-shallowing cycle is interpreted to be a parasequence that is capped by a marine-flooding surface. Although not totally clear, the parasequences appear to exhibit deposits that reflect an initial minor transgressive phase followed by a regressive phase (Figure 3) as opposed to being completely asymmetric upward-shoaling cycles with only a regressive phase. Cycles are often incomplete or irregular in terms of the lithologies and lithofacies. The upwardshallowing and coarsening cycles generally exhibit upward-decreasing GR well-log signatures punctuated by a sharp increase in GR at the top of each cycle that corresponds to the flooding surface. An overall increase in GR occurs from the north-northwest to south-southeast, indicating an increase in clay content.

Based on lithofacies stacking patterns observed in core and compared to well logs (GR, NPHI, RhoB, RILD), the Meramec is divided into eight parasequences (Figures 10 and 11). The key surfaces that cap each parasequence or reservoir zone are the Osage and the eight Meramec zones (from base to top: A, B10, B, C, D, E, F, G) (Figures 3, 10 and 11).

\section{Lithology, Rock-Type, and Petrophysical-Property Models}

To constrain the spatial distribution of lithologies, rock-types, and petrophysical properties, vertical variograms were created and ranges were estimated that vary from 2 to $7 \mathrm{ft}$ (0.6 to $2.1 \mathrm{~m})$. Based on qualitative trends, lithology horizontal variogram ranges were set to $4000 \mathrm{ft}(1220 \mathrm{~m})$ and $2000 \mathrm{ft}(610 \mathrm{~m})$ in the major and minor directions, respectively; and to $3500 \mathrm{ft}(1065 \mathrm{~m})$ and $1750 \mathrm{ft}(530 \mathrm{~m})$ for rock types. Horizontal variogram ranges for petrophysical properties are less than ranges for lithologies and rock types and are set to $3000 \mathrm{ft}$ $(915 \mathrm{~m})$ and $1500 \mathrm{ft}(460 \mathrm{~m})$ in the major and minor directions, respectively. Vertical variogram 

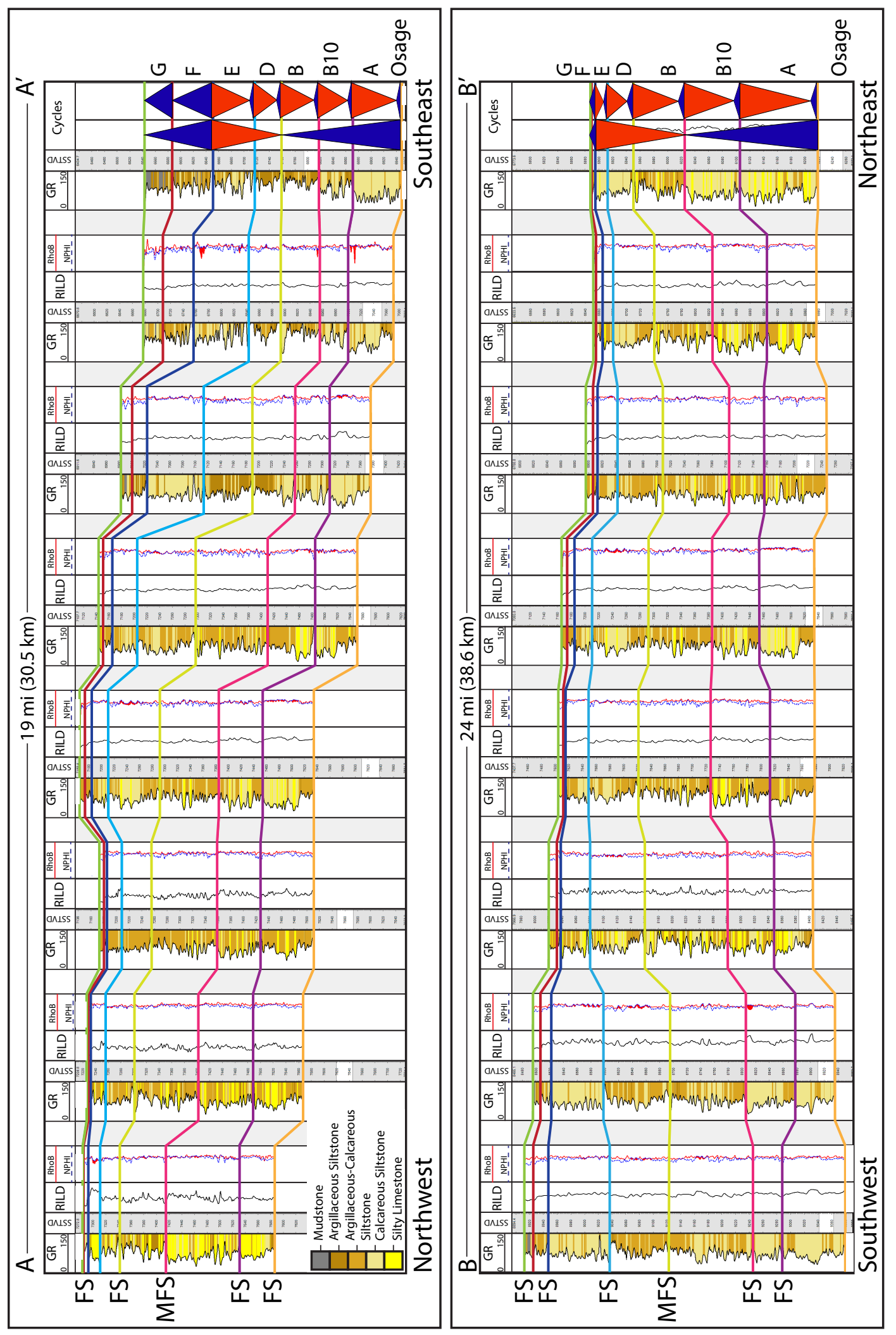
Figure 10: Regional cross sections through the study area flattened on the Late Devonian Woodford shale, displaying the interpreted internal stratigraphic zones of the Mississippian Meramec. The GR track is shaded by the lithology classifications and was used as a guide for stratigraphic correlations. (A) represents a northwest-southeast dip-oriented crosssection showing the progradational nature of the clinoforms in the study area. Calcareousrich lithologies are prevalent in the northwest transitioning to clay-rich lithologies in the southeast, moving into the basin. (B) represents a northeast-southwest, strike oriented cross-section, showing an increase in the overall thickness of the Meramec. 

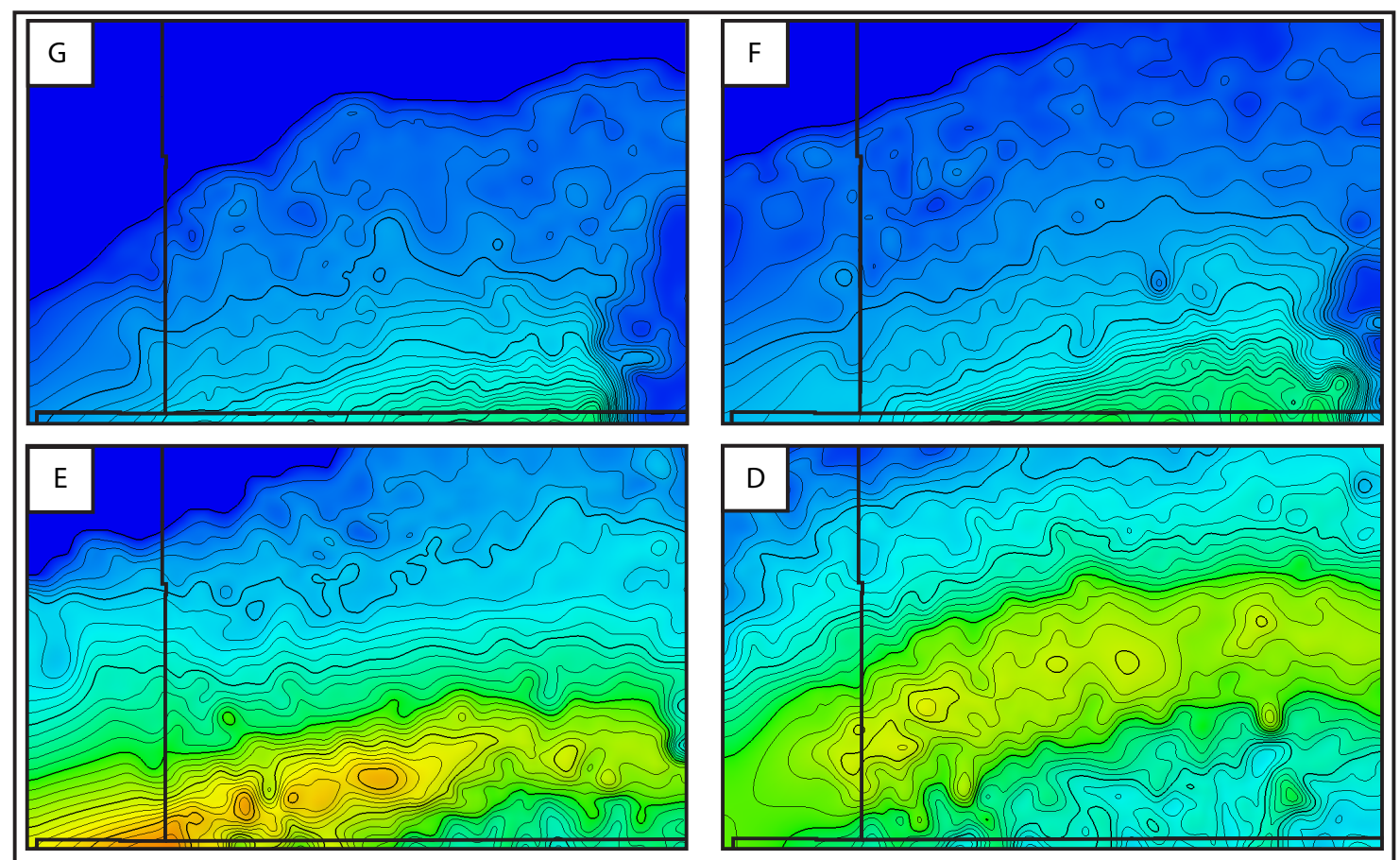

Thickness
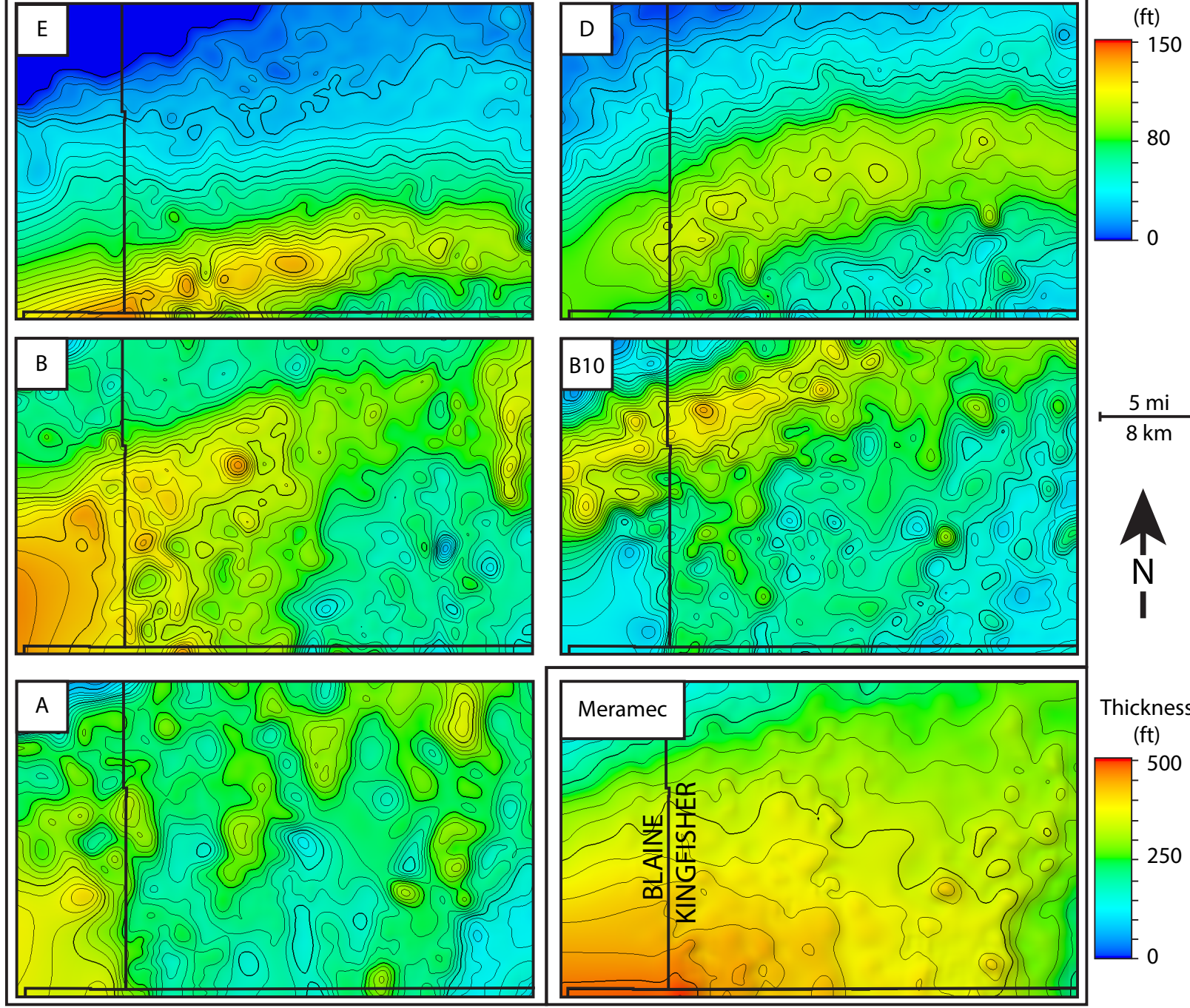

Thickness

(ft)

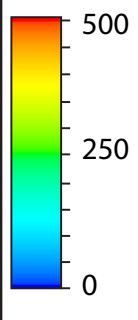

Figure 11: Interpreted parasequence isopach maps for the Meramec A-G and the entire Meramec. Depositional dip indicated by the isopachs is to the southeast with depositional strike occurring at approximately $70^{\circ}$ from the north. 
ranges for petrophysical properties vary from 2 to $3 \mathrm{ft}$ ( 0.6 to $0.9 \mathrm{~m})$ (Appendix-C6 through C9).

For the lithology model, parasequences A, B10, and B show lithologies that backstep to the northwest, and represent a retrogradational clinoform set with an upward increase in argillaceous-rich lithologies (18 to $34 \%$ ) and decrease in calcareous-rich lithologies (61 to $37 \%$ ) (Figures 12 and 13). Parasequence B is capped by a maximum flooding surface and is comprised of primarily argillaceous-rich lithologies. The parasequence stacking patterns suggest that parasequences $\mathrm{D}$ through $\mathrm{E}$ form an aggradational to progradational parasequence set (progradation to southeast) as indicated by upward-coarsening vertical lithology successions, becoming more calcareous rich (30 to $64 \%$ ) moving up section into parasequence E. Parasequences $\mathrm{F}$ and $\mathrm{G}$ overly parasequence $\mathrm{E}$ and represent a retrogradational parasequence set, back step to the northwest, and contain more argillaceous-rich facies (23 to $52 \%$ ), with the majority of the mudstone in the study area present in parasequence $G$ to the southeast (basinward).

For the rock-type model, parasequences A, B10 and B also show rock types that backstep to the northwest, with an increase in the clay-rich rock type $1(6.8$ to $33.1 \%)$ and a decrease in the carbonate-rich rock type 3 (39.3 to $12.4 \%$ ) moving up section (Figures 12 and 13). Meramec E displays a significant increase (38.5\%) in the amount of rock type 3 followed by a significant increase of rock type 1(54.0 and 78.6 \%) in the overlying Meramec F and G, respectively. The vertical proportion curves for lithologies and rock types (Figure 3) both show the same retrogradational-progradational-retrogradational trend, indicating a positive relationship.

Total porosity in the study area ranges from $0-10 \%$ with some anomalous readings of $15 \%$, primarily occurring in the very clay rich Meramec F and G. Porosity increases distally into 

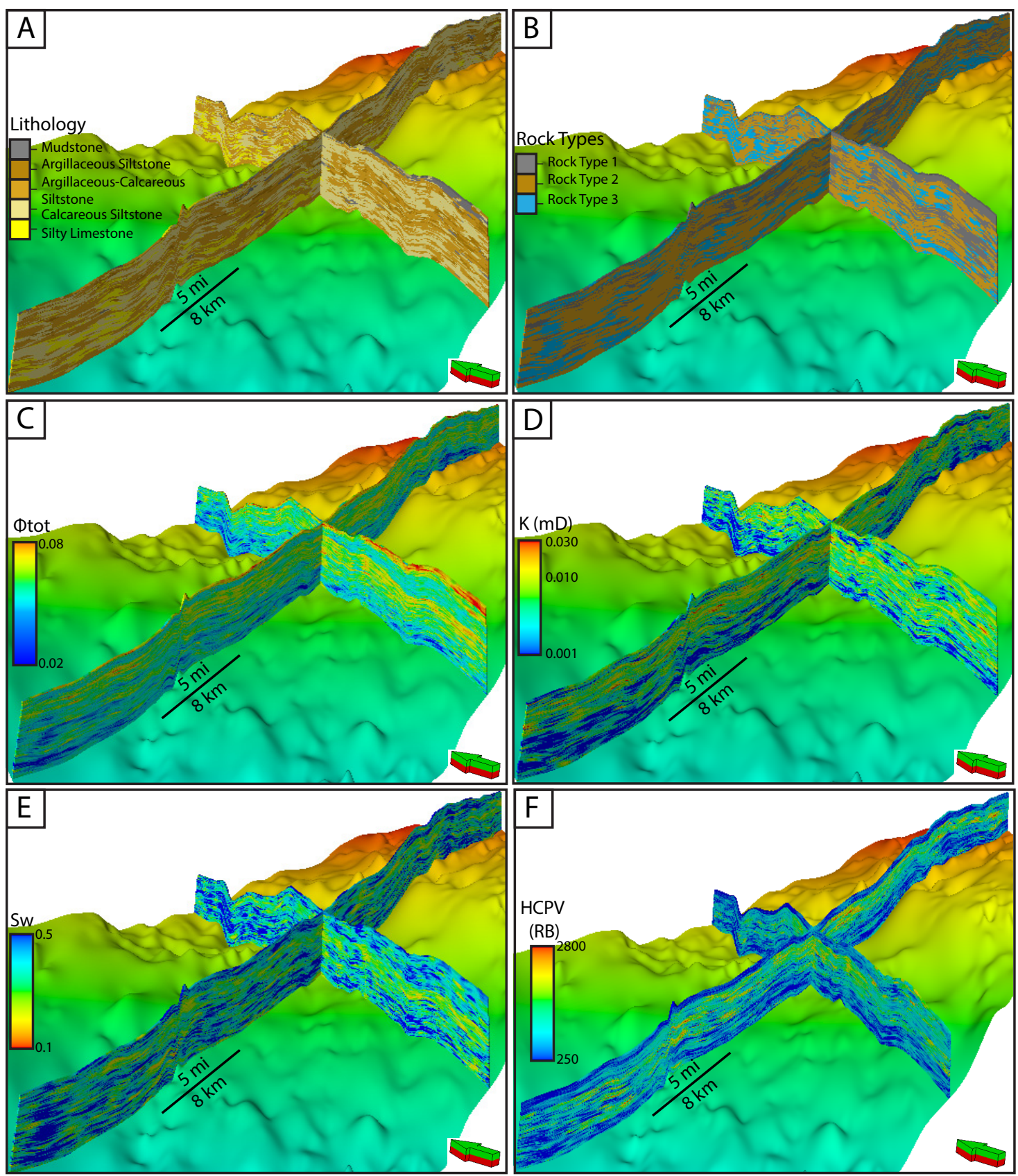

Figure 12: Northwest-southeast and northeast-southwest slices of the 3-D modeling results with the Osage horizon shown. (A) is the lithology model and (B) is the rock type model. (C) porosity (D) permeability and (E) water saturation models were constrained to the rock type model. (F) is the resulting P50 hydrocarbon pore volume model. Comparing all 6 models, petrophysical properties are observed to be controlled by the distribution of calcite-clay content. 

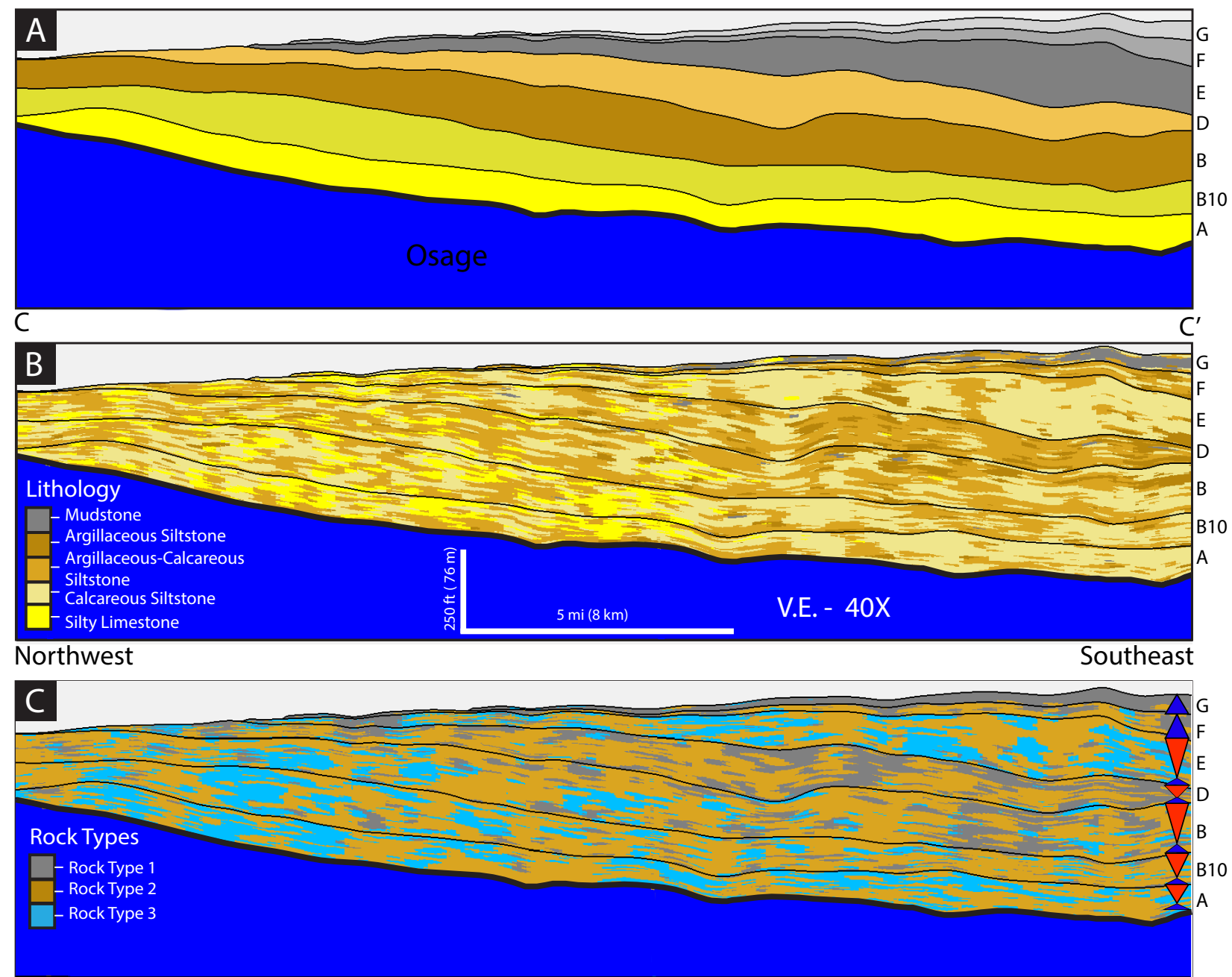

Figure 13: Northwest-southeast oriented cross-sections through the 3-D model flattened on the Late Devonian Woodford shale horizon. (A) shows the 7 stratigraphic zones and the progradational nature of the clinoforms associated with the Meramec in the study area overlying the Osage. (B) shows the spatial distribution of the lithologies within the study area. Meramec A, $\mathrm{B}, \mathrm{B} 10$ and D display an overall decrease in calcareous-rich lithologies moving up section with an increase in clay-rich lithologies indicative of a rise in sea-level and retrogradation. Meramec E shows an increase in calcareous-rich lithologies with Meramec F and G showing an increase in clay-rich lithologies indicating a drop in sea-level followed by a rise in sea-level respectively. C) shows the spatial distribution of the rock types within the study area. Meramec A, B, B10 and D display an overall decrease in rock type 1 moving up section with an increase in clay-rich lithologies indicative of a rise in sea-level and retrogradation. Meramec E shows an increase in calcareous-rich rock type 3 with Meramec F and G showing an increase in clay-rich rock type 1 indicating a drop in sea-level followed by a rise in sea-level respectively. The models shown represent the P50 realization based on uncertainty analysis discussed in the Volumetric and Production Analysis section. 
the basin to the southeast, with lower porosity values occurring proximal to the northwest. The porosity model (Figures 12 and 14) shows increasing porosity moving up section in relationship to increasing argillaceous-rich lithology and rock types, with lower average porosity for the Meramec A (2.7\%) and higher average values in parasequences B10, B, and D (3.4, 4.4, and $5.3 \%$, respectively). Transitioning into the Meramec E, the average porosity is observed to be 3.9 $\%$, which is a decrease associated with an increase in calcareous-rich lithologies and rock types. In the Meramec $\mathrm{F}$ and $\mathrm{G}$ average porosity is 6.1 and $7.1 \%$, respectively, which represents an increase in average porosity associated with an increase in argillaceous-rich lithologies and rock types.

Permeability measurements from core range from $0.01 \mu \mathrm{D}$ to $0.1 \mathrm{mD}$. The average permeability of the Meramec in the study area is low; approximately $4.5 \mu \mathrm{D}$. Trending from northwest to southeast, permeability increases moving proximal to distal into the basin (Figures 12 and 14). The permeability model (Figures 12 and 14) shows increasing permeability moving up section in relationship to increasing argillaceous-rich lithology and rock types, with lower average permeability for the Meramec A $(2.4 \mu \mathrm{D})$ and higher average values in parasequences $\mathrm{B} 10, \mathrm{~B}$, and $\mathrm{D}(3.2,4.9$, and $6.8 \mu \mathrm{D}$, respectively). Transitioning into the Meramec $\mathrm{E}$, the average permeability is observed to be $4.1 \mu \mathrm{D}$, which is a decrease associated with an increase in calcareous-rich lithologies and rock types. In the Meramec F and G average permeability is 7.3 and $6.1 \mu \mathrm{D}$, respectively, which represents an increase in average permeability associated with an increase in argillaceous-rich lithologies and rock types.

Water saturation is variable throughout the study area. The water saturation $\left(S_{w}\right)$ model (Figures 12 and 14) shows decreasing $S_{w}$ moving up section in relationship to increasing argillaceous-rich lithology and rock types, with higher average $S_{w}$ for the Meramec A (45\%) and 

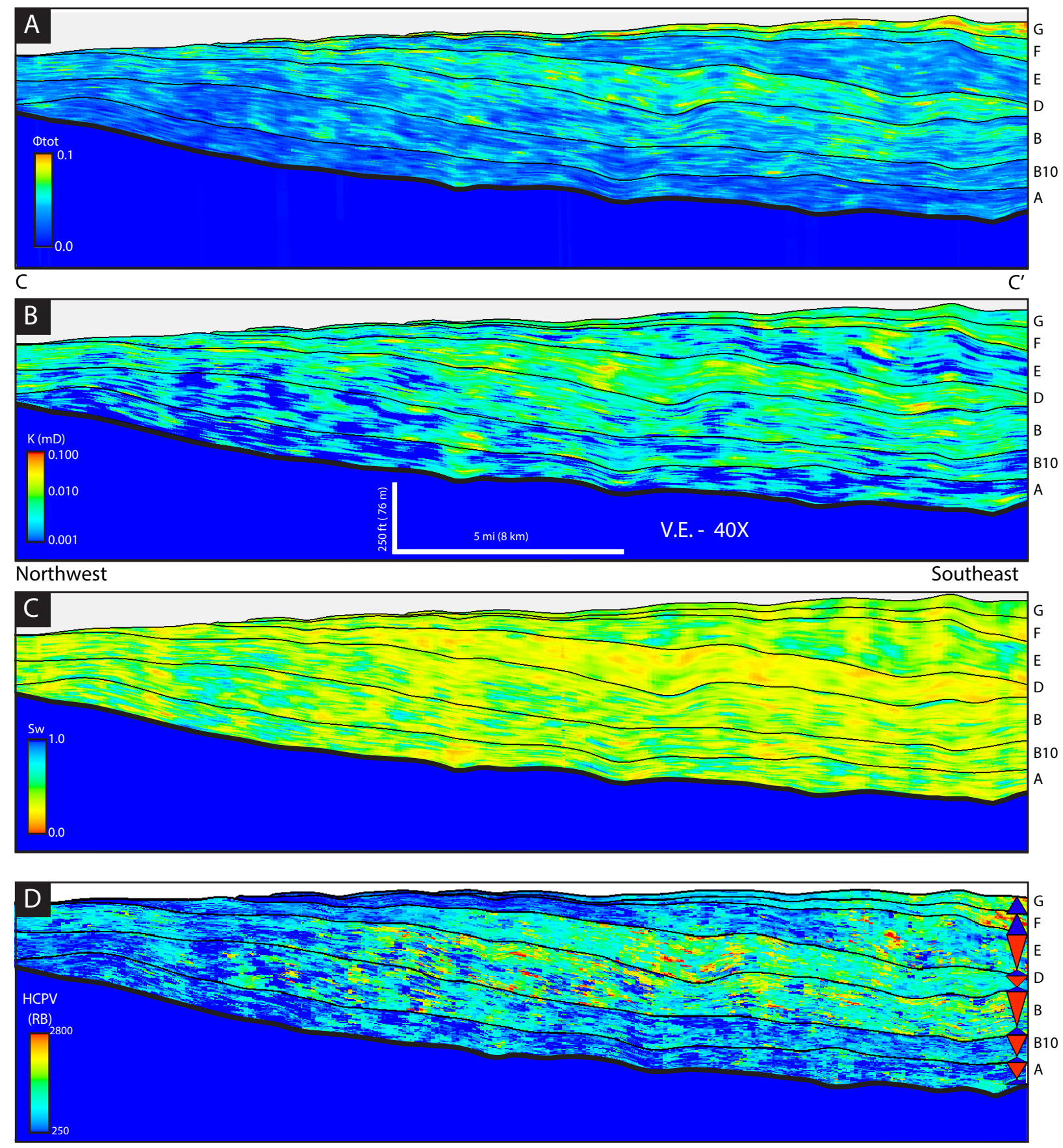
Figure 14: Northwest-southeast oriented cross-sections through the 3-D model flattened on the Late Devonian Woodford shale horizon. (A) shows the spatial distribution of porosity within the study area. Meramec A, B, B10 and D display an overall increase in porosity moving up section with an increase in clay-rich lithologies and rock types indicative of a rise in sea-level and retrogradation. Meramec E shows a decrease in porosity with Meramec $\mathrm{F}$ and $\mathrm{G}$ showing an increase in porosity indicating a drop in sealevel followed by a rise in sea-level respectively. (B) shows the spatial distribution of permeability within the study area. Meramec A, B, B10 and D display an overall increase in permeability moving up section with an increase in clay-rich lithologies and rock types indicative of a rise in sea-level and retrogradation. Meramec E shows a decrease in permeability with Meramec $\mathrm{F}$ and $\mathrm{G}$ showing an increase permeability indicating a drop in sea-level followed by a rise in sea-level respectively. (C) shows the spatial distribution of water saturation within the study area. Meramec A, B, B10 and D display an overall decrease in water saturation moving up section with an increase in clay-rich lithologies and rock types. Meramec E shows an increase in water saturation with Meramec F and G showing a decrease in water saturation. Water saturation is observed to be highest with calcareous-rich lithologies and rock types. (D) shows the spatial distribution of HCPV within the study area. Meramec A, B, B10 and D display an overall increase in HCPV moving up section with an increase in clay-rich lithologies and rock types. Meramec E shows a decrease in HCPV with Meramec F and G showing an increase in water HCPV. The models shown represent the P50 realization based on uncertainty analysis discussed in the Volumetric and Production Analysis section. 
lower average values in parasequences B10, B, and D (44, 41, and $34 \%$, respectively).

Transitioning into the Meramec E, the average $S_{w}$ is observed to be $44 \%$, which is an increase associated with an increase in calcareous-rich lithologies and rock types. In the Meramec F and G average $S_{w}$ is 38 and $44 \%$, respectively, which represents a decrease in average $S_{w}$ associated with an increase in argillaceous-rich lithologies and rock types for the Meramec F, but waterbound clay is thought to explain the increase in average $S_{w}$ in association with the onset of mudstone in Meramec G.

\section{Volumetric and Production Analysis}

Used herein, in terms of pore volume and hydrocarbon pore volume (HCPV) in reservoir barrels (RB), P10 represents the more conservative volumetric outcome of the models with P90 representing the optimistic volumetric output (Figure 15). The P10, P50, and P90 rock-type models (Appendix-D1) contain similar percentages of rock types 1,2 and 3, $(23 \%, 50.8 \%$, and $26.2 \%$, respectively).

Through uncertainty analysis (25 realizations), pore volume, HCPV, and HCPV per section in reservoir barrels (RB) were calculated and P10, P50, and P90 cases are reported (Table 4). The P10, P50 and P90 pore volume amounts are $42,089 \times 10^{6}, 42,138 \times 10^{6}$, and $42,175 \times 10^{6}$ $\mathrm{RB}$, respectively; resulting in $<1 \%$ difference between values. HCPV amounts are 27,043 x 10 , $27,093 \times 10^{6}$, and $27,131 \times 10^{6} \mathrm{RB}$ for the P10, P50, and P90 cases, respectively. The P50 HCPV model (Figures 12 and 14) shows increasing average HCPV moving up section in relationship to increasing argillaceous-rich lithology and rock types, with lower average HCPV for the Meramec A $\left(541 \times 10^{6} \mathrm{RB}\right)$ and higher average values in parasequences $\mathrm{B} 10, \mathrm{~B}$, and $\mathrm{D}(542$, 910, and $898 \times 10^{6} \mathrm{RB}$, respectively). Transitioning into the Meramec E, the average HCPV is 


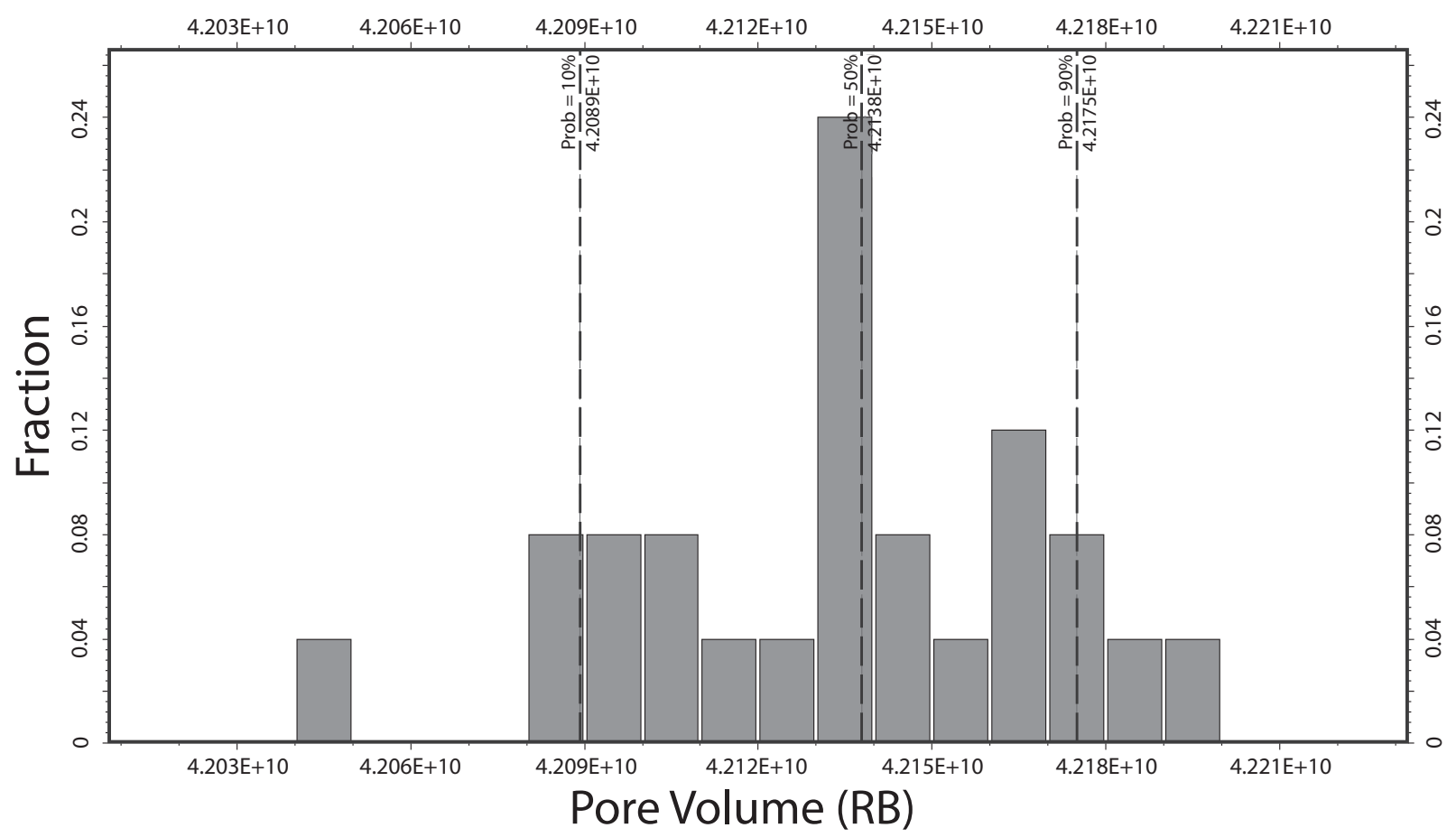

Figure 15: Histogram of pore volume calculated through 25 iterations in an uncertainty analysis. P10, P50 and P90 values of pore volume are displayed via the horizontal dashed lines. The y-axis is the fraction of iterations that correspond to the calculated pore volume on the $\mathrm{x}$-axis. 


\begin{tabular}{|l|r|r|r|r|}
\hline \multicolumn{5}{|c|}{ P10 Volumetric Calculations } \\
\hline \multicolumn{1}{|c|}{ Zone } & $\begin{array}{c}\text { Bulk Volume } \\
\left(* 10^{6} \mathrm{ft}^{3}\right)\end{array}$ & $\begin{array}{c}\text { Pore Volume } \\
\left(* 10^{6} \mathrm{RB}\right)\end{array}$ & $\begin{array}{c}\text { Hydrocarbon Pore } \\
\text { Volume }\left(* 10^{6} \mathrm{RB}\right)\end{array}$ & $\begin{array}{c}\text { HCPV per section } \\
\left(* 10^{6} \mathrm{RB}\right)\end{array}$ \\
\hline MRMC_G & & 2294 & 1323 & \\
\hline MRMC_F & 255521 & 2909 & 1905 & 5.98 \\
\hline MRMC_E & 790275 & 5623 & 3443 & 10.86 \\
\hline MRMC_D & 946236 & 9077 & 6256 & 11.74 \\
\hline MRMC_B & 1348926 & 10495 & 6764 & 6.78 \\
\hline MRMC_B10 & 1058487 & 6231 & 3906 & 5.98 \\
\hline MRMC_A & 1117578 & 5460 & 3446 & 41.35 \\
\hline Total & 5694149 & 42089 & 27043 & \\
\hline
\end{tabular}

\begin{tabular}{|l|r|r|r|r|}
\hline \multicolumn{7}{|c|}{ P50 Volumetric Calculations } \\
\hline \multicolumn{7}{|c|}{ Zone } & $\begin{array}{c}\text { Bulk Volume } \\
\left(* 10^{6} \mathrm{ft}^{3}\right)\end{array}$ & $\begin{array}{c}\text { Pore Volume } \\
\left(* 10^{6} \mathrm{RB}\right)\end{array}$ & $\begin{array}{c}\text { Hydrocarbon Pore } \\
\text { Volume }\left(* 10^{6} \mathrm{RB}\right)\end{array}$ & $\begin{array}{c}\text { HCPV per section } \\
\left(* 10^{6} \mathrm{RB}\right)\end{array}$ \\
\hline MRMC_G & 177127 & 2307 & 1336 & 6.00 \\
\hline MRMC_F & 255521 & 2886 & 1886 \\
\hline MRMC_E & 790275 & 5638 & 3454 & 10.87 \\
\hline MRMC_D & 946236 & 9074 & 6263 & 67.71 \\
\hline MRMC_B & 1348926 & 10482 & 6746 & 6.84 \\
\hline MRMC_B10 & 1058487 & 6263 & 3938 & 6.02 \\
\hline MRMC_A & 1117578 & 5488 & 3469 & 41.44 \\
\hline Total & 5694149 & 42138 & 27093 & \\
\hline
\end{tabular}

\begin{tabular}{|l|r|r|r|r|}
\hline \multicolumn{7}{|c|}{ P90 Volumetric Calculations } \\
\hline \multicolumn{7}{|c|}{ Zone } & $\begin{array}{c}\text { Bulk Volume } \\
\left(* 10^{6} \mathrm{ft}^{3}\right)\end{array}$ & $\begin{array}{c}\text { Pore Volume } \\
\left(* 10^{6} \mathrm{RB}\right)\end{array}$ & $\begin{array}{c}\text { Hydrocarbon Pore } \\
\text { Volume }\left({ }^{*} 10^{6} \mathrm{RB}\right)\end{array}$ & $\begin{array}{c}\text { HCPV per section } \\
\left({ }^{1} 10^{6} \mathrm{RB}\right)\end{array}$ \\
\hline MRMC_G & 177127 & 2292 & 1326 & 5.98 \\
\hline MRMC_F & 255521 & 2893 & 1887 \\
\hline MRMC_E & 790275 & 5614 & 3443 & 10.92 \\
\hline MRMC_D & 946236 & 9103 & 6288 & 11.78 \\
\hline MRMC_B & 1348926 & 10525 & 6786 & 6.83 \\
\hline MRMC_B10 & 1058487 & 6257 & 3933 & 6.02 \\
\hline MRMC_A & 1117578 & 5491 & 3467 & 41.52 \\
\hline Total & 5694149 & 42175 & 27131 & \\
\hline
\end{tabular}

Table 4: Results from the volumetric analysis for P10, P50, P90 and base case scenarios. 
observed to be $535 \times 10^{6} \mathrm{RB}$, which is a decrease associated with an increase in calcareous-rich lithologies and rock types. In the Meramec F and G average HCPV is 853 and $778 \times 10^{6} \mathrm{RB}$, respectively, which represents an increase in average HCPV associated with an increase in argillaceous-rich lithologies and rock types.

Average pore volume and HCPV maps (Figure 16, Appendix-D5 to Appendix-D9) for P10, P50, and P90 cases show their spatial distribution. The greatest pore volume and HCPV amounts are associated with parasequences B and D. HCPV per section was also calculated for the entire Meramec $\left(\sim 41 \times 10^{6} \mathrm{RB}\right)$ and for each parasequence A-E (Table 4).

Through cross-plots, 180-day production was compared to lithology, rock type, porosity, permeability, water saturation, average stage length in the lateral, and average amount of stages in the lateral, to determine if there was a correlation between these parameters and reservoir productivity (Appendix-E1 to Appendix-E5). Based on this qualitative analysis, there are no clear trends between 180-day production and these reservoir parameters. However, when looking at the comparison between 180-day normalized production and rock type 2(Appendix-E4), a loose correlation can be made. The cross-plot shows that production potentially increases with an increase in rock type 2 . With this said, completion design can significantly impact the reservoir rock and associated fault and fracture networks; therefore, it can be difficult to make assumptions when comparing production back to the reservoir parameters without a more thorough and complex analysis. 


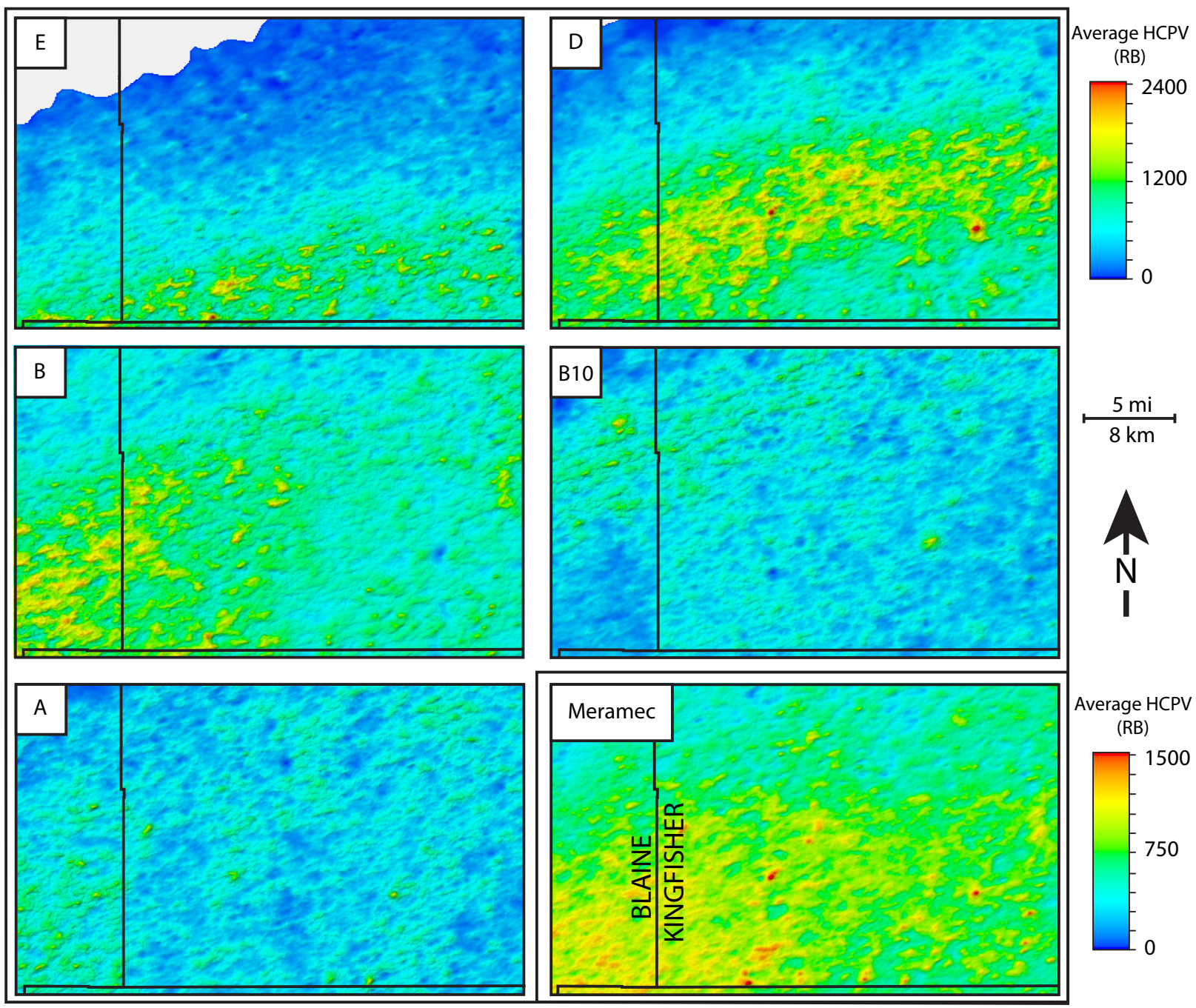

Figure 16: Average maps for hydrocarbon pore volume (HCPV) for the Meramec A, B10, B, D and $\mathrm{E}$ and for these intervals combined (Meramec). An upward increasing trend in HCPV is visible from Meramec A-D, then decreasing in the Meramec E. 


\section{DISCUSSION}

\section{The K-means dilemma with lithology classification}

K-means clustering is a powerful and simple machine learning tool, used to identify patterns in data and cluster the data based on similarities. Its use, however, entails certain restrictive assumptions about the data which come with consequences that might not be immediately apparent (Raykov et al., 2016). In this study, K-means clustering achieved low $\operatorname{accuracies}(k=3)$ when clustering mudstone, argillaceous siltstone and argillaceous-calcareous siltstone in Well A utilizing three different well-log suites ([GR, NPHI, RhoB, PE], [GR, NPHI, RhoB, RILD], [GR, NPHI, RhoB]), resulting in overall classification accuracies of 47.9, 48.9 and $50.0 \%$ (Table 3 ) when comparing the clustered data back to the cored-defined lithology log. It did however achieve high accuracies when clustering calcareous siltstone. The issue with the lower accuracies may lie in the subtle gradational nature of one lithology into another with no clear end-members, the variability of clay and calcite in the lithologies and how these lithologies unique well-log signatures subtly differ from one another in some instances.

\section{Reservoir parameters and implications on reservoir quality}

The Mississippian Meramec consists of mixed carbonate-siliciclastic deposits that have undergone significant change since deposition due to uplift and exposure, burial, relative sealevel changes, and diagenesis. Unlike the reservoirs of the "Mississippi Lime" to the north, where diagenesis allowed for enhanced moldic and intercrystaline porosity in spiculitic and chert-rich deposits (Wethington and Pranter, 2018), the Meramec in the STACK area is a very low porosity and permeable rock. Two of the driving factors on reservoir quality in the Meramec are clay and calcite-cement abundance. Porosity is lower in more calcareous-rich lithologies while argillaceous-rich lithologies exhibit higher porosity (Figure 17). This is thought to be the 

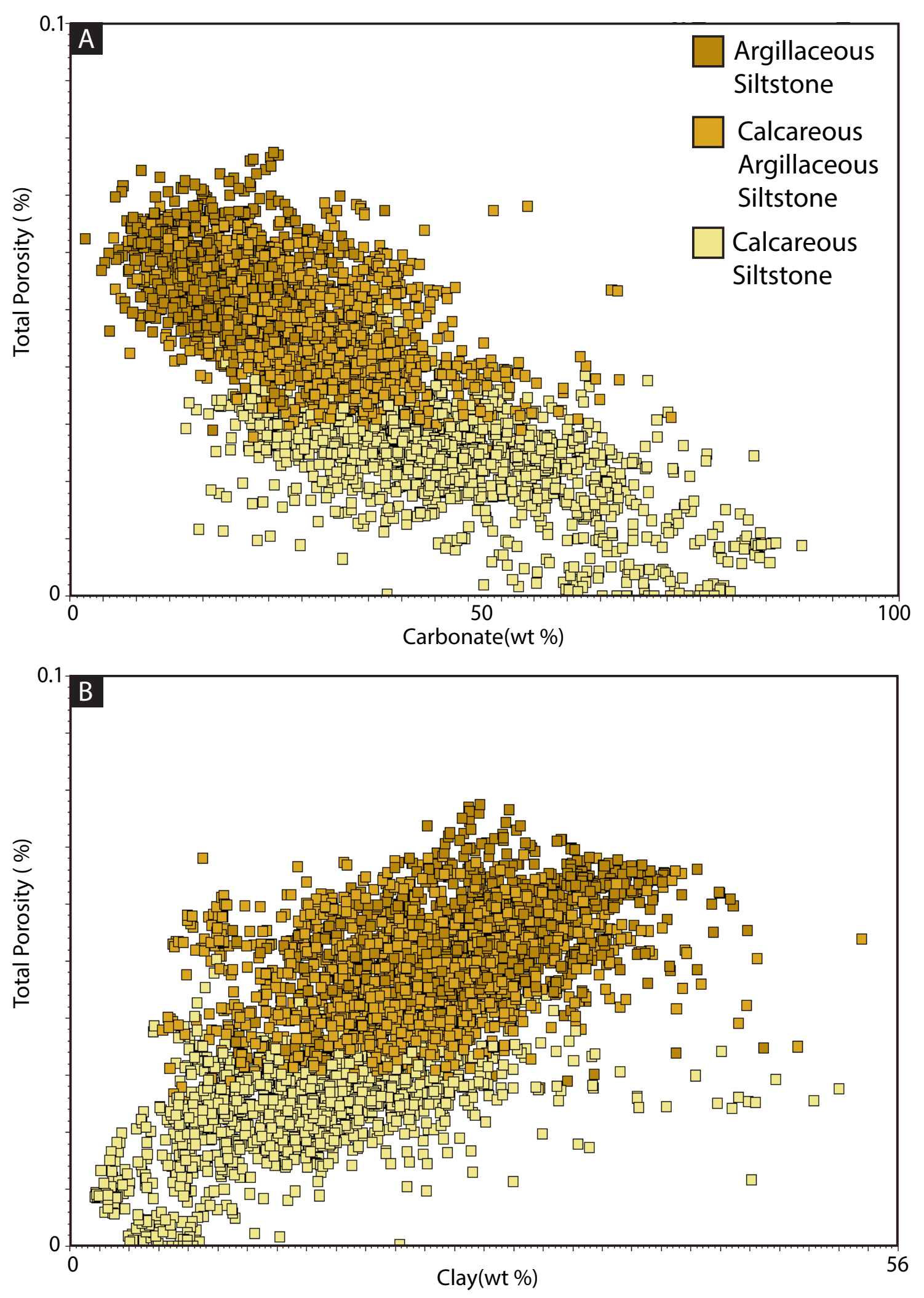
Figure 17: Cross-plots of A) calcite versus total porosity and B) clay versus total porosity. The data points are colored by classified lithologies determined from the artificial neural network. 
result of clay particles partially lining grains and pores and limiting the onset of calcite cementation during diagenesis, thus preserving primary pore space. In support of this, Hardwick (2018) found that in the Meramec, the primary loss of porosity and permeability can be attributed to onset of calcite cementation and that interstitial clay allowed for the preservation of primary pore space. In addition, (D. Larese, 2018, personal communication) found that there were two dominant diagenetic processes prevalent in the study area that controlled porosity: 1) burial compaction and 2) chemical compaction. Burial compaction resulted in deformation of detrital clay, ductile deformation, and grain breakage and rotation. While clays conformed to other detrital grains such as calcite and quartz, interstitial voids were created, thus preserving pore space and contributing to overall porosity (D. Larese, 2018, personal communication). Chemical compaction resulted in sutured grain contacts and stylolites. Chemical cementation resulted in calcite-dolomite cements, followed by quartz and then pyrite. Clays inhibit chemical compaction and reduce quartz cementation (D. Larese, 2018, personal communication). Observations suggest that permeability, aligning with porosity, appears to favor the more argillaceous lithologies and rock types. As a result of diagenetic controls on porosity, it is inferred that permeability is also directly impacted by the same processes that affected porosity.

With observations on the petrophysical models, the stratigraphic and lateral variability of petrophysical properties, pore volume and HCPV are directly related to calcite cement and the distribution of clays throughout the study area. Furthermore, the distribution of lithologies, rock types and petrophyscial properties in addition to pore volume and HCPV suggest that the Meramec B and D are the best intervals in the Meramec for production. Both zones contain the optimal proportions of the best lithologies and rock types along with the best porosity, permeability, pore volume and HCPV and the lowest water saturations. 


\section{CONCLUSIONS}

The Mississippian Meramec is comprised of mixed carbonate-siliciclastic sediments that were deposited on a broad, regionally extensive carbonate ramp to distal basinal setting in relatively shallow warm waters. High-frequency sea level fluctuations in the shallow water setting impart a large control on the distribution of facies. The Mississippian Meramec in the STACK area consists primarily of 5 lithologies: 1) mudstone, 2) argillaceous siltstone, 3 ) argillaceous-calcareous siltstone, 4) calcareous siltstone and 5) silty limestone; and 8 lithofacies: 1) structureless mudstone, 2) silty laminated mudstone, 3) silty bioturbated mudstone, 4) calcareous bioturbated siltstone, 5) calcareous laminated siltstone, 6) very fine grained calcareous structureless sandstone to very course siltstone, 7) very fine grained calcareous, crossstratified sandstone to very course siltstone, and 8) skeletal silty packstone to grainstone. Directly related to lithology, 3 rock types based upon core porosity-permeability relationships were calculated using a flow-zone indicator (FZI) approach. Machine learning methods were used to classify lithologies in non-cored wells. The use of an Artificial Neural Network, a supervised method of machine learning, produced an overall accuracy of $93 \%$. This was completed with a log suite as an input comprised of GR, NPHI, RHOB and PE. Verification of classification accuracy was validated through qualitative measures using core mineralogy crossplots.

The Meramec stratigraphic framework consists of 8 parasequences. The parasequences stack to form a retrogradational parasequence set overlain by an aggradational to progradational parasequence set. The uppermost two parasequences are also retrogradational in character. The parasequence stacking, associated lithology distribution, and diagenetic cements appear to control the distribution of petrophyscial properties, pore volume, and hydrocarbon pore volume. 
Calcareous-rich lithologies have lower porosity, permeability and HCPV and exhibit higher water saturation. Argillaceous-rich lithologies associated with the uppermost interval of the retrogradational parasequence set (zone B) and lower part of the overlying parasequence set (zone D) appear to be the more favorable reservoir rock in the Meramec. Parasequences B and D exhibit higher porosity, permeability and HCPV and lower water saturation exhibiting the optimal reservoir quality. 


\section{REFERENCES}

Adler, F. J., 1971, Petroleum potential of the Anadarko Basin and central Oklahoma area, AAPG Memoir 15, v. 2, p. 1061-1072.

Allen, D.B., and M.J. Pranter, 2016, Geologically constrained electrofacies classification of fluvial deposits: an example from the Cretaceous Mesaverde group, Uinta and Piceance basins: AAPG Bulletin, v. 100, no. 12, p. 1775-1801.

Amaefule, J., M. Altunbay, D. Tiab, D. Kersey, and D. Keelan, 1993, Enhanced reservoir description: Using core and log data to identify hydraulic (flow) units and predict permeability in un-cored intervals/wells: Proceedings of SPE Annual Technical Conference and Exhibition, doi:10.2523/26436-ms.

Ball, M. M., M. E. Henry, and S. E. Frezon, 1991, Petroleum geology of the Anadarko Basin region, province (115), Kansas, Oklahoma, and Texas: Department of the Interior U.S. Geological Survey, 36 p.

Beebe, B.W., 1959, Characteristics of Mississippian production in the northwestern Anadarko Basin, Tulsa Geological Society Digest, V. 27, p. 190-205.

Blakey, R., 2011, Paleogeography and geologic evolution of North America, http://cpgeostystems.com/paleomaps.html, (accessed March 2018).

Boyd, D.T., 2008, Stratigraphic guide to Oklahoma oil and gas reservoirs: Oklahoma Geological Society, Special Publication 2008-1, 2 p.

Burke, K., and J.F. Dewey, 1973, Plume-generated triple junctions; key indicators in applying plate tectonics to older rocks: Journal of Geology, v. 81, p. 406-433.

Campbell, J. A., C. J. Mankin, A. B. Schwarzkopf, and J. J. Raymer, 1988, Habitat of petroleum in Permian rocks of the Midcontinent region; in, Permian Rocks of the Midcontinent, W. A. Morgan and J. A. Babcock, eds.: Midcontinent Society of Economic Paleontologists and Mineralogists, Special Publication No. 1, p. 13-35.

Comer, J.B., 1991, Stratigraphic analysis of the Upper Devonian Woodford formation, Permian Basin, west Texas and southeastern New Mexico: Bureau of Economic Geology Report of Investigations, no. 201, p. 20-35.

Curtis, D. M. and S. C. Champlin, 1959, Depositional environments of Mississippian limestones of Oklahoma: Tulsa Geological Society Digest, vol. 27, p. 90-103.

Drummond, K., 2018, Regional stratigraphy and proximal to distal variation of lithology and porosity within a mixed carbonate-siliciclastic system, Meramec and Osage series (Mississippian), central Oklahoma, M.S. Thesis, University of Oklahoma, Norman, Oklahoma, $165 \mathrm{p}$. 
Duarte, D., 2018, Rock characterization and stratigraphy of the Mississippian strata, Meramec/Sycamore merge play, central Oklahoma, M.S. Thesis, University of Oklahoma, Norman, Oklahoma, 80 p.

Dutton, S.P., 1984, Fan-Delta Granite Wash of the Texas panhandle, Oklahoma City Geological Society, vol. Short Course Notes.

Flinton, K. C., 2016, The effects of high-frequency cyclicity on reservoir characteristics of the "Mississippian Limestone", Anadarko Basin, Kingfisher county, Oklahoma, M.S. Thesis, Oklahoma State University, Stillwater, Oklahoma, 412 p.

Grammer G. M., D. Boardman, J. Puckette, J. Gregg, J. Priyank., M. Childress, B. J. Price, B. Vanden Berg, and S. LeBlanc, 2013, Integrated reservoir characterization of Mississippianage Midcontinent carbonates: AAPG Search and Discovery Article \#30297, 31 p.

Gutschick, R. C., and C. A. Sandberg, 1983, Mississippian continental margins of the conterminous United States: in D. J. Stanley, and G. T. Moore, eds., The Shelfbreak: Critical Interface on Continental Margins: SEPM Special Publication 33, p. 79-96.

Ham, W. E., R. E. Denison, and C. A. Merritt, 1965, Basement rocks and structural evolution of southern Oklahoma- a summary: AAPG Bulletin, vol. 49, no. 7, p. 927-934.

Haq, B.U., and S.R. Schutter, 2008, A chronology of Paleozoic sea-level changes: Science, v. 322 , p. 64-68.

Hardwick, J., 2018, Reservoir quality evaluation of the Meramec and Upper Osage units in the Anadarko Basin, M.S. thesis, University of Oklahoma, Norman, Oklahoma, 76 p.

Hartigan, J.A., 1975, Clustering algorithms: New York, John Wiley \& Sons, p. 84-107.

Hickman, G., 2018, Parasequence-scale stratigraphic variability of lithology and porosity of Mississippian Meramec reservoirs and the relationships to production characteristics, STACK trend, Oklahoma, M.S. Thesis, University of Oklahoma, Norman, Oklahoma, 105 p.

Jannsen, L.F., and F.M. Van der Wel, 1994, Accuracy assessment of satellite derived land-cover data: a review: Photogrammetric Engineering and Remote Sensing, v. 60, p. 419-426.

Johnson, K. S. and K. V. Luza, 2008, Earth sciences and mineral resources of Oklahoma, Educational Publication 9, Oklahoma Geological Survey, 22 p.

Kohavi, R., and F. Provost, 1998, Special issue on applications of machine learning and the knowledge discovery process: Kluwer Academic Publishers, Boston, 271 p. 
Kumar, B. and M. Kishore, 2006, Electrofacies classification - a critical approach: $6^{\text {th }}$ International conference and exposition on petroleum geophysics, Kilkata, india, p. 822825 .

Kanungo, T., D. Mount, N. Netanyahu, C. Piatko, R. Silverman, and A. Wu, 2002, An efficient $\mathrm{K}$-means clustering algorithm, analysis and implementation, pattern analysis and machine intelligence: IEEE Transactions on pattern analysis and machine intelligence, v. 24, no. 7, p. 881-892.

Lane, H. R., and T. L. De Keyser, 1980, Paleogeography of the late Early Mississippian (Tournaisian 3) in the central and south-western United States, Paleozoic paleogeography of the west-central United States: Rocky Mountain Section SEPM, p. 149-158.

Leavitt, A., 2018, Depositional systems of the STACK and SCOOP Mississippian units; regional understanding from logs and core, STACK play Workshop Technical Program and Core Viewing, Norman, Oklahoma.

LeBlanc, S. E., 2014, High resolution sequence stratigraphy and reservoir characterization of the "Mississippian Limestone" in north-central Oklahoma, M.S. Thesis, Oklahoma State University, Stillwater, Oklahoma, 443 p.

Lindzey, K.M., M.J. Pranter, K.J. Marfurt, 2017, Lithological and petrophysical controls on production of the Mississippian Limestone, northeastern Woods County, Oklahoma, in G.M. Grammer, J.M. Gregg, J.O. Puckette, P. Jaiswal, S.J. Mazzullo, M.J. Pranter, and R.H. Goldstein, eds., Mississippian Reservoirs of the Midcontinent, AAPG Memoir 116.

LoCricchio, E., 2012, Wash Play Overview, Anadarko Basin: Stratigraphic framework and controls on Pennsylvanian granite wash production, Anadarko Basin, Texas and Oklahoma, AAPG Search and Discovery Article, no. 110163.

Mazullo, S. J., and B. W. Wilhite, 2010, CHERT, TRIPOLITE, SPICULITE, CHAT -WHAT'S IN A NAME? Kansas Geological Society Bulletin, v. 85, no. 1.

Mazzullo, S. J., 2011, Mississippian oil reservoirs in the southern Midcontinent: new exploration concepts for a mature reservoir objective: Search and Discovery Article \#10373.

Mazzullo, S. J., B. W. Wilhite, D. R. Boardman, B. T. Morris., and C. J. Godwin, 2016, Stratigraphic architecture and petroleum reservoirs in lower to Middle Mississippian strata (Kinderhookian to basal Meramecian) in subsurface central to southern Kansas and northern Oklahoma: Shale Shaker, vol. 67 no. 2, p. 20-49.

McConnell, D.A., M.J. Goyda, G.N. Smith, and J.P. Chitwood, 1989, Morphology of the frontal fault zone, southwest Oklahoma: Implications for deformation and deposition on the Wichita Uplift and Anadarko Basin: Geology, vol. 18, no. 7, p.34-637 
Miller, J., 2018, Regional stratigraphy and organic richness of the Mississippian Meramec and associated strata, Anadarko basin, central Oklahoma, M.S. thesis, University of Oklahoma, Norman, Oklahoma, $154 \mathrm{p}$.

Northcutt, R. A. and J. A. Campbell., 1995, Geologic provinces of Oklahoma: Oklahoma Geological Survey Open-File Report 5-95, 1 sheet, scale 1: 750000, 6-page explanation and bibliography.

Northcutt, R.A., K. S. Johnson, and G. C. Hinshaw, 2001, Geology and petroleum reservoirs in Silurian, Devonian, and Mississippian rocks in Oklahoma: Oklahoma Geological Survey Circular 105, p. 1-15.

Parham, K.D., and R.A. Northcutt, 1993, Mississippian chert and carbonate and basal Pennsylvanian sandstone - central Kansas uplift and northern Oklahoma, D. Bebout, W. White, and T. Hentz, eds.: Atlas of major Midcontinent gas reservoirs, Austin, Bureau of Economic Geology, p. 57-59.

Peeler, J.A., 1985, Reservoir characterization of the Mississippian "chat," Hardtner field, southern Barber County, Kansas: M.S. thesis, Wichita State University, Wichita, Kansas, p. 120.

Perry, W. J., 1990, Tectonic evolution of the Anadarko Basin region, Oklahoma: Department of the Interior, US Geological Survey, no 1866-A, 19 p.

Price, B., K. Haustveit, and A. Lamb, 2017, Influence of stratigraphy on barriers to fracture growth and completion optimization in the Meramec Stack Play, Anadarko Basin, Oklahoma: Unconventional Resources Technology Conference (URTEC), Article \#2697585, 8 p.

Price, B. J., and G.M. Grammer, 2018, High resolution sequence stratigraphic architecture and reservoir characterization of the Mississippian Burlington/Keokuk Formation, northwestern Arkansas, in G.M. Grammer, J.M. Gregg, J.O. Puckette, P. Jaiswal, S.J. Mazzullo, M.J. Pranter, and R.H. Goldstein, eds., Mississippian Reservoirs of the Midcontinent: AAPG Memoir 116, doi: 10.1306/13632147M1163787.

Raykov, Y. P., A. Boukouvalas, F. Baig, and M. A. Little, 2016, What to do when K-means Clustering Fails: A simple yet principled alternative algorithm: Plos One, v. 11, no. 9, doi: 10.1371/journal.pone.0162259.

Read, J.F., 1995, Overview of Carbonate Platform Sequences, Cycle Stratigraphy and Reservoirs in Greenhouse and Icehouse Worlds, in Read, J.F., Kerans, C., Weber, L.J., Sarg, J.F., and Wright, F.M. (eds.), Milankovitch Sea Level Changes, Cycles, and Reservoirs on Carbonate Platforms in Greenhouse and Icehouse Worlds: SEPM Short Course 35, p. 1-102.

Rogers, S.M., 2001, Deposition and diagenesis of Mississippian chat reservoirs, north-central Oklahoma: AAPG Bulletin, v.85, no.1, p. 115-129. 
Serra, O., and H.T. Abbott, 1980, The contribution of logging data to sedimentary sedimentology and stratigraphy, SPE-9270: Society of Petroleum Engineers, presented at $55^{\text {th }}$ Annual Technical Conference and Exhibition [Dallas], preprint, 19 p. Later published in 1982, Society of Petroleum Engineers Journal, v. 22, no. 1, p. 117-131.

Smith, L. I., 2002, A Tutorial on Principle Component Analysis: University of Otago: http://www.cs.otago.ac.nz/cosc453/student_tutorials/principal_components.pdf.

Sloss, L. L., 1963, Sequences in the cratonic interior of North America: Geological Society of America Bulletin, vol. 74, no. 2, p 93-114.

Ting, K. M., 2011, Confusion matrix, in C. Sammut and G.I. Webb, eds., Encyclopedia of machine learning, $1^{\text {st }}$ ed: New York, Springer, 209 p.

Turnini, A. M., M. J. Pranter, K. J. Marfurt, 2017, Mississippian limestone and chert reservoirs, Tonkawa Field, north-central Oklahoma, in G. M. Grammer, J. M. Gregg, J. O. Puckette, P. Jaiswal, S. J. Mazzullo, M. J. Pranter, and R. H. Goldstein, eds., Mississippian Reservoirs of the Midcontinent, AAPG Memoir 116.

Watney, W. L., W. J. Guy, and A. P. Bynes, 2001, Characterization of the Mississippian chat in south-central Kansas: AAPG Bulletin, vol. 85, p. 85-113.

Wagstaff, K., C. Cardie, S. Rogers, S. Schroed1, 2001, Constrained K-means Clustering with Background Knowledge: Proceedings of the Eighteenth International Conference on Machine Learning, p. 577-584.

Wethington, N.W., and M.J. Pranter, 2018, Stratigraphic Architecture of the Mississippian Limestone through integrated electrofacies classification, Hardtner Field area, Kansas and Oklahoma, Interpretation, v. 6, no. 4, 22p.

Wickham, J. S., 1978, The southern Oklahoma aulacogen, Geological Society of America, In structural style of the Arbuckle region, south-central section guidebook for field trip 3, p. 941 .

Witzke, B.J., 1990, Paleoclimatic constraints for Paleozoic paleolatitudes of Laurentia and Euramerica, W.S. McKerrow and C.R. Scotese, eds. Paleogeography and biogeography: Geological Society (London) memoir 12, p. 57-73. 


\section{APPENDIX}

\section{LIMITATIONS}

This section addresses some of the limitations that were encountered during the scientific method process and recommended solutions that could be used to better improve the results.

\section{Log Normalization}

Log normalization was not performed on the digital las well logs in the 1155 wells in the study area. This could affect the end results of the subsequent models generated in this study.

\section{Production Analysis}

A simple production analysis was conducted in this study relating 180-day normalized production to reservoir parameters. Due to the complex methods that are required in hydrocarbon extraction in unconventional reservoirs, a more detailed and equally complex analysis would need to be conducted in an attempt to understand the relationship between production and reservoir parameters. Other variables such as reservoir pressure, GOR and structure are a few variables that could be examined to further correlate production to reservoir parameters moving forward. 


\section{APPENDIX A: Geologic Setting}

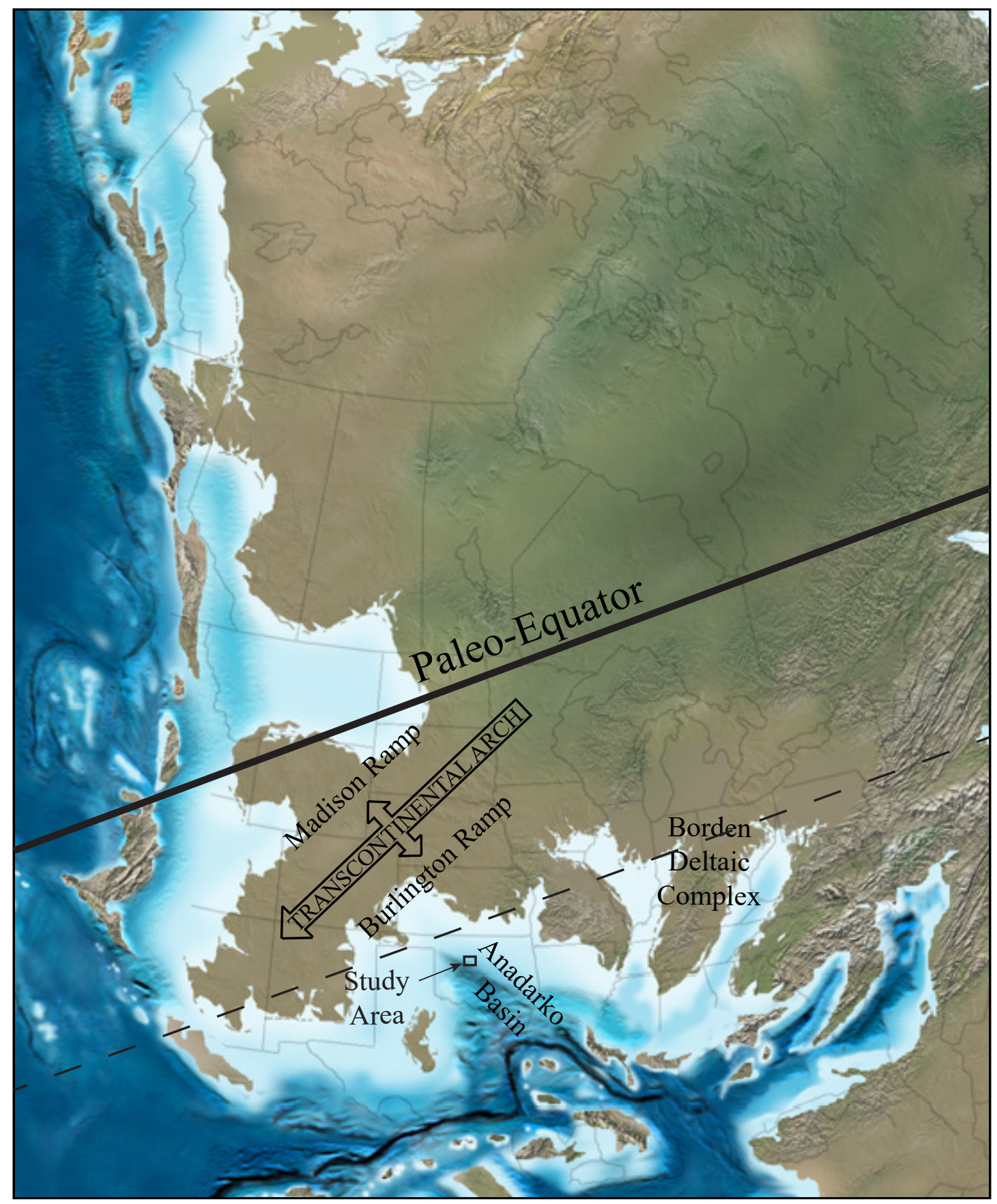

Appendix A1. Late Mississippian paleogeographic map. The study area, as marked by the black box, is located the Anadarko basin southeast of the Transconticnental Arch and paleoequator, positioned approximately between 20-30o S, southeast of the paleoequator. 


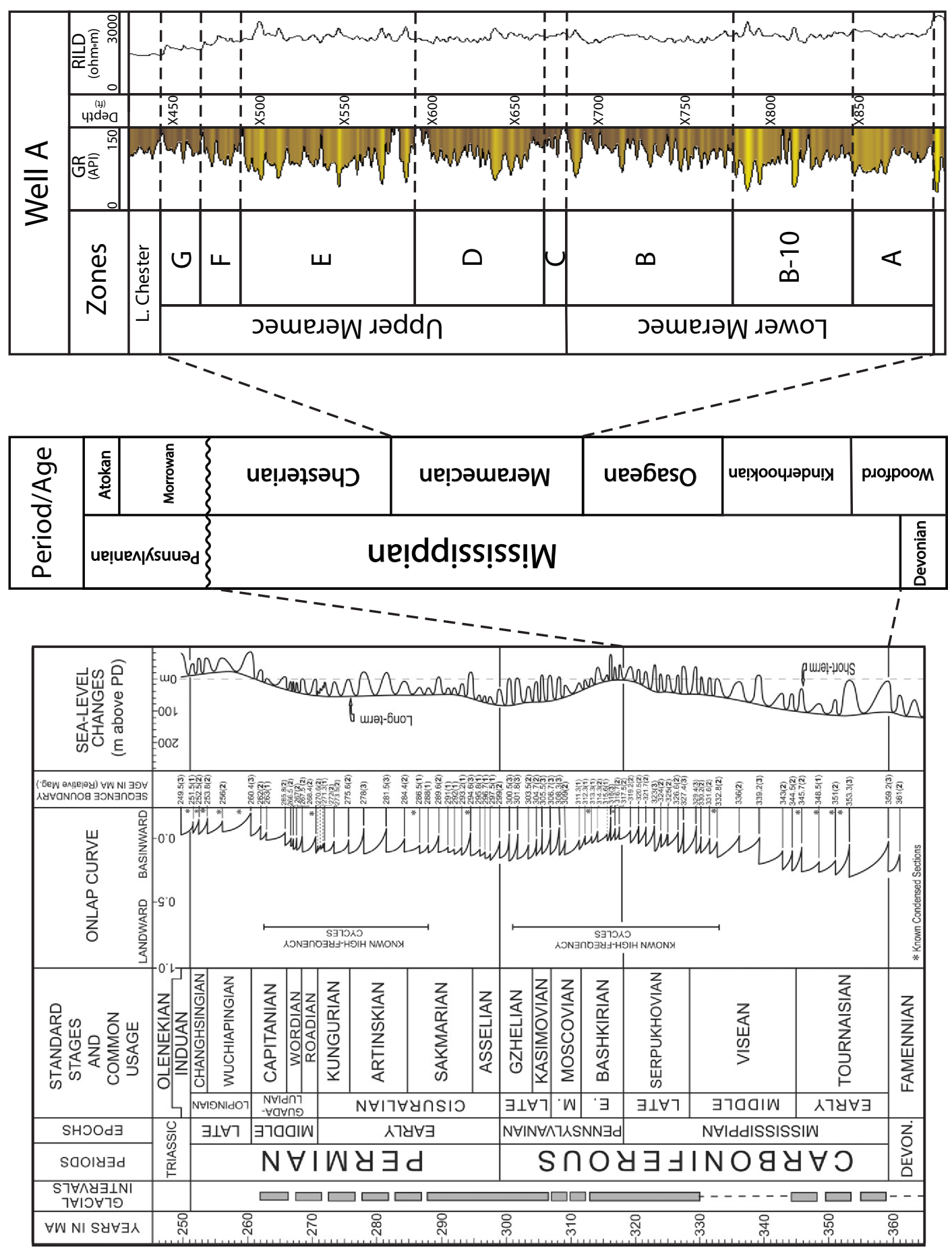

Appendix A2. Global onlap and sea level curve for the Carboniferous-Permian period tied to a generalized Mississippian stratigraphic column and Meramec type $\log$ from the study area. The Meramec was deposited during a transition from greenhouse to icehouse climate conditions, resulting in increasing cyclicity with the rise and fall of sea level thus affecting deposition (modified from Boyd, 2008; Haq and Schutter, 2008) 


\section{APPENDIX B: Core Data}

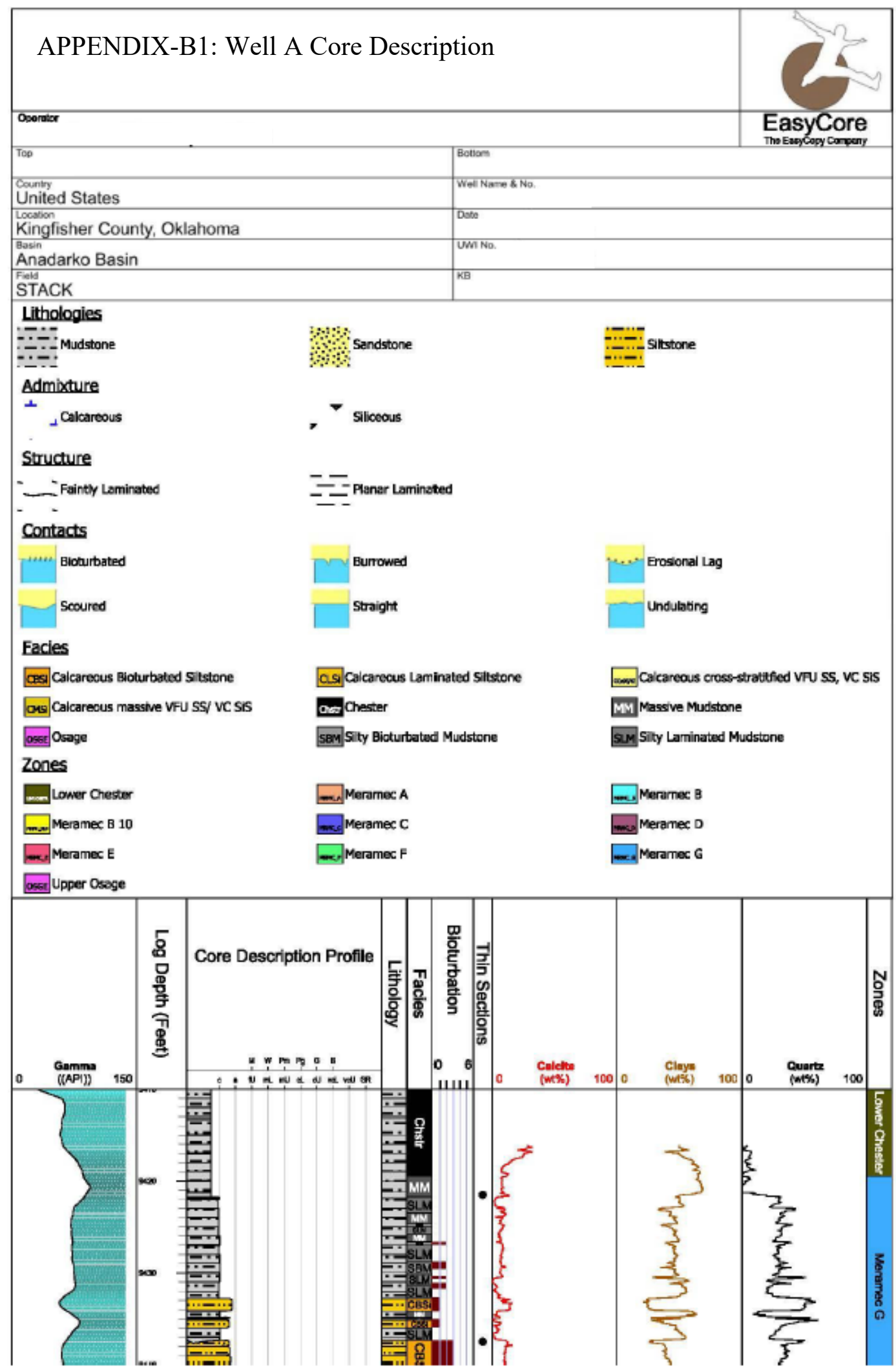




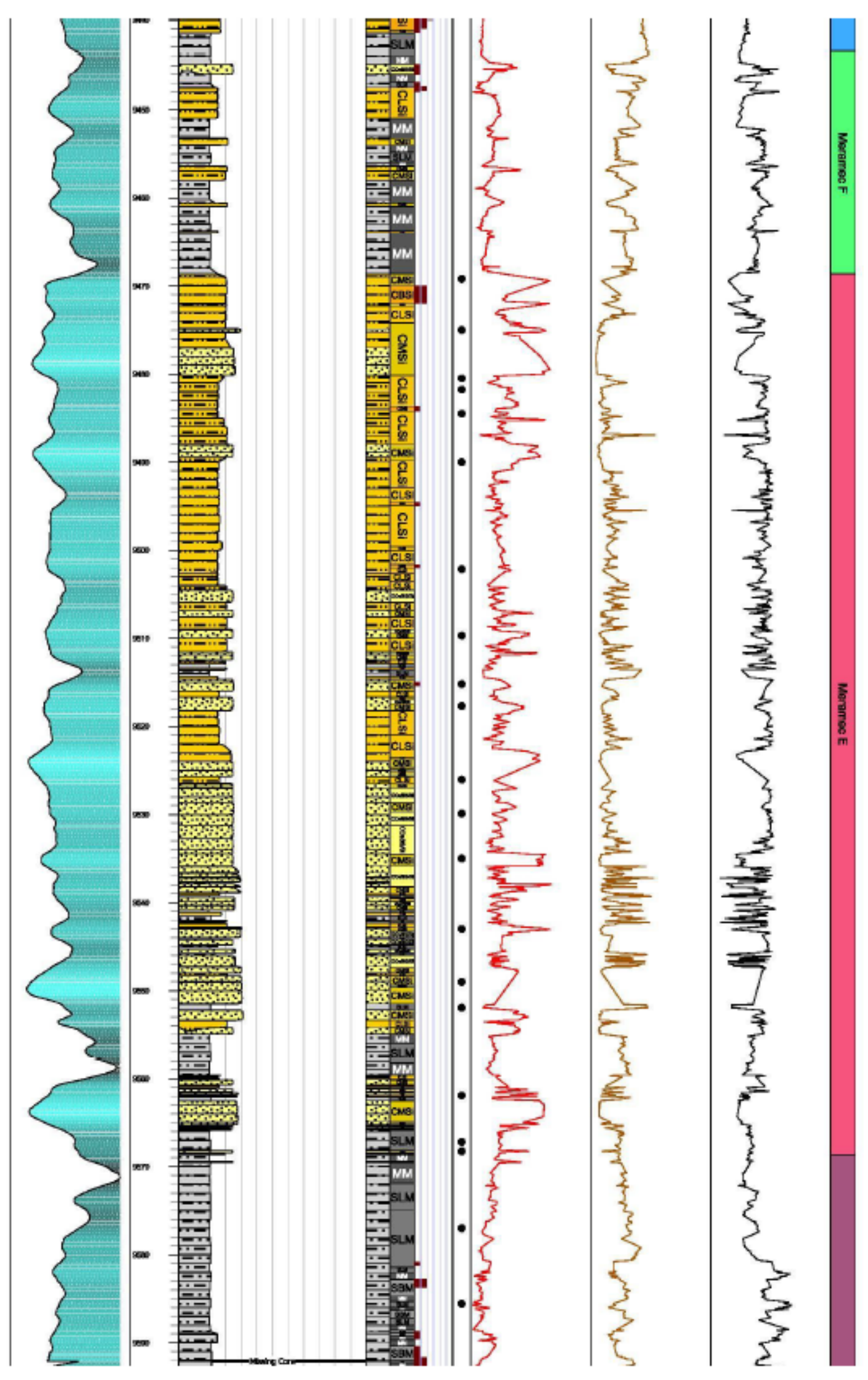




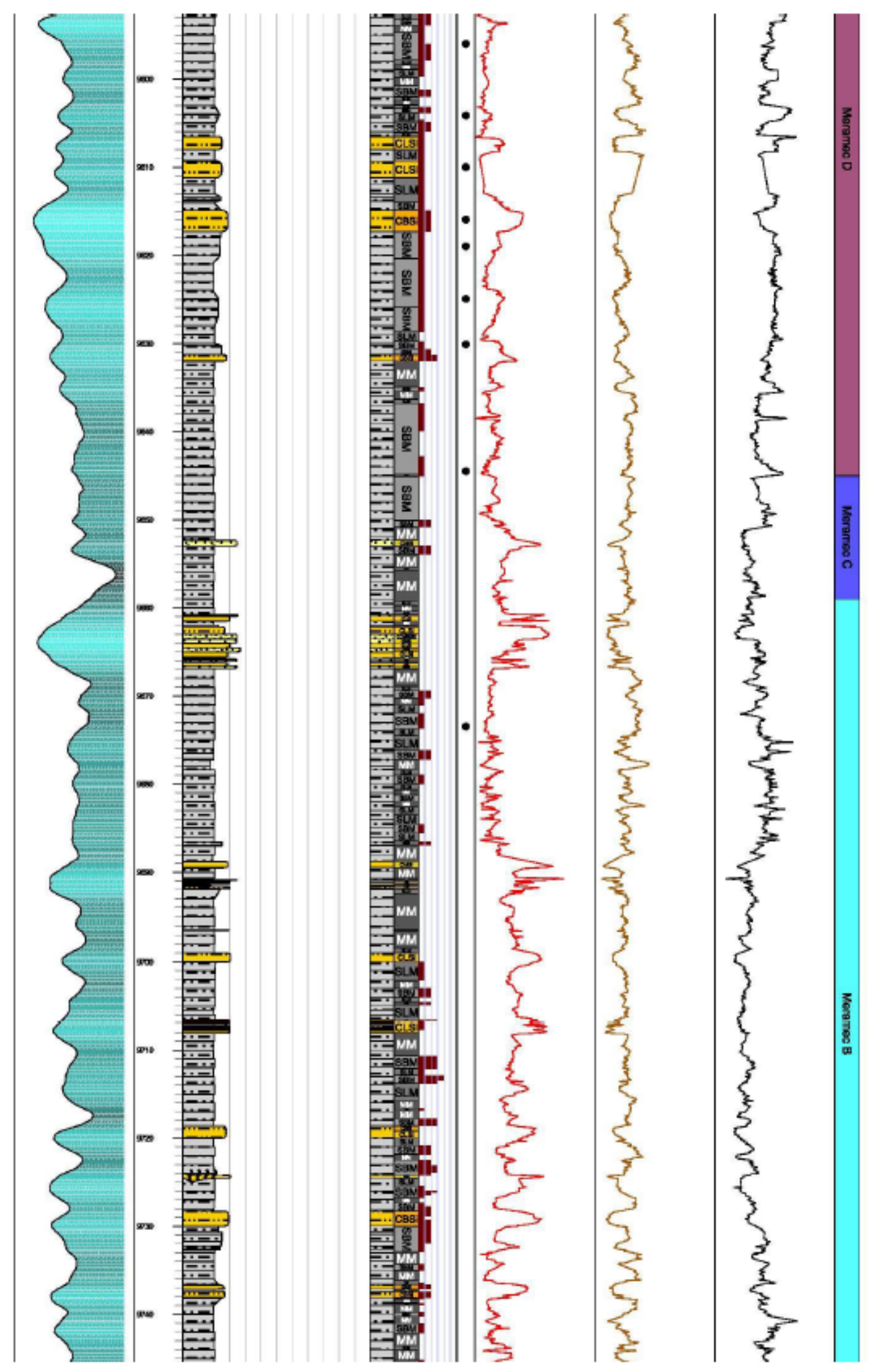




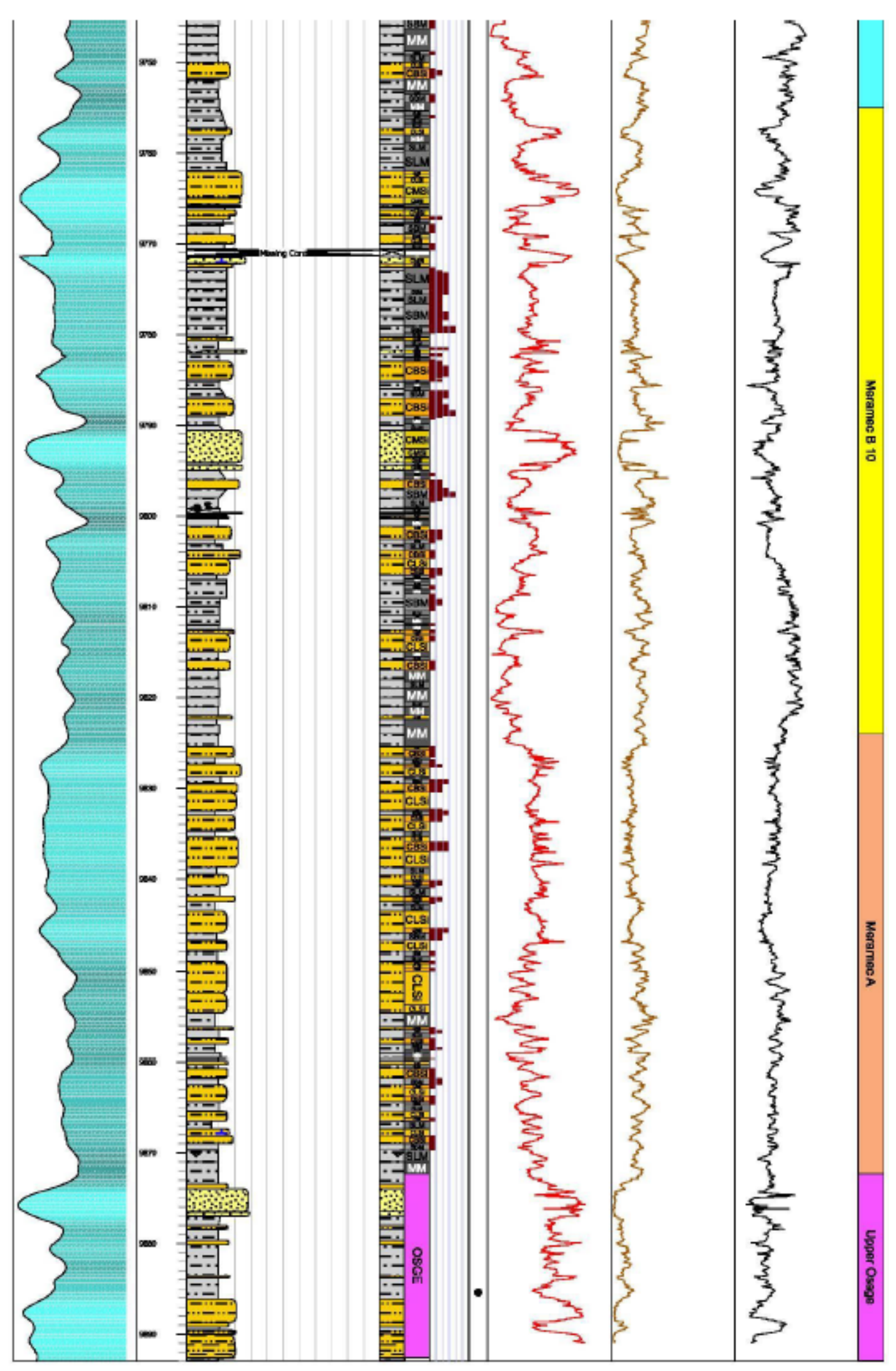




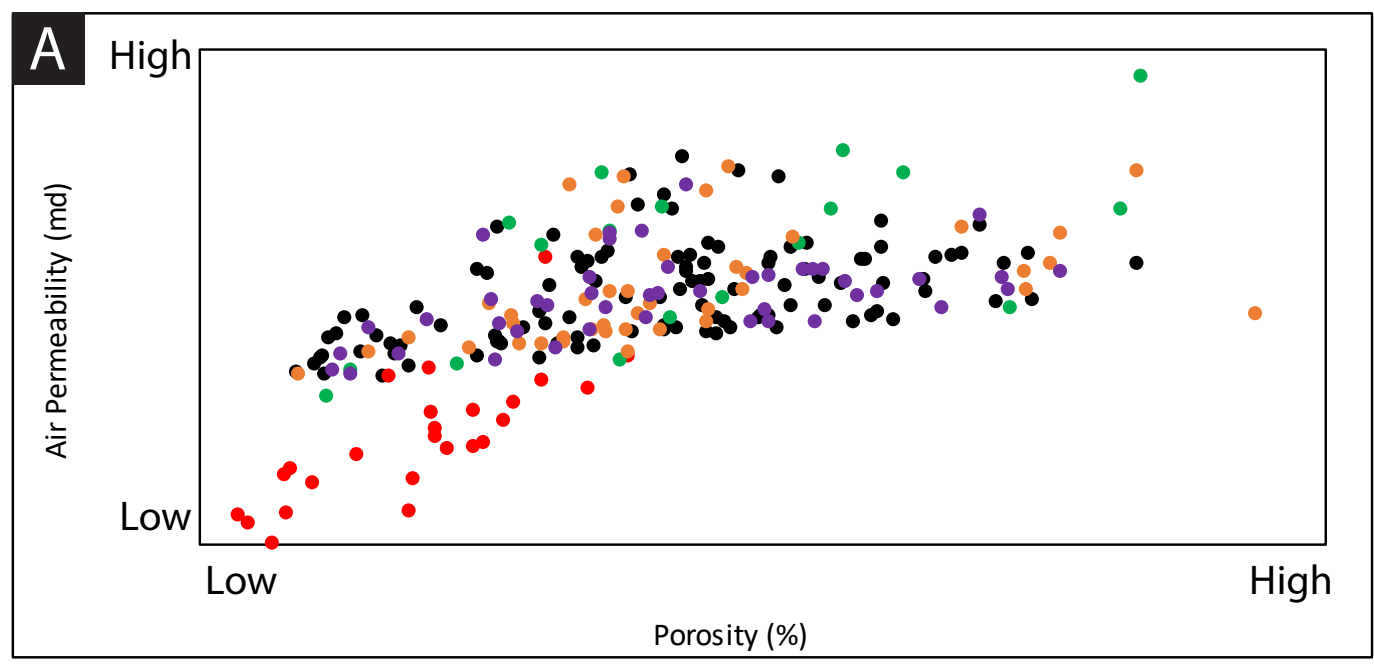

MRO 1-14H Rosemary Gulf Oil 1-23 Shaffer \& 1-25 Shaffer OPIC Others

MRO 1-25 Tyler MRO 1307 Siegrist Payrock 1506 McCarthy

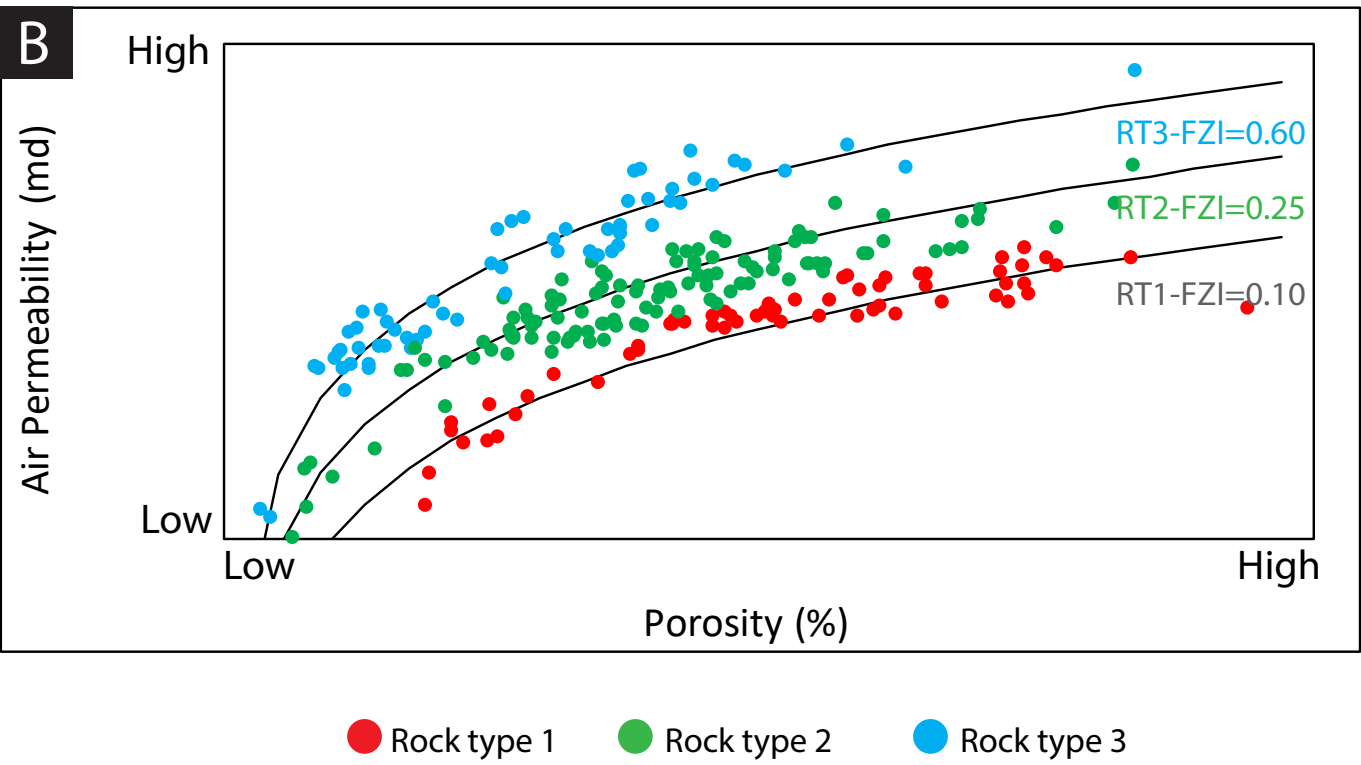

Appendix-B2: A) shows a cross-plot of core measured air permeability (md) versus porosity for the listed wells. B) is the same cross-plot with the data colored by rock type after an FZI equation was applied. 

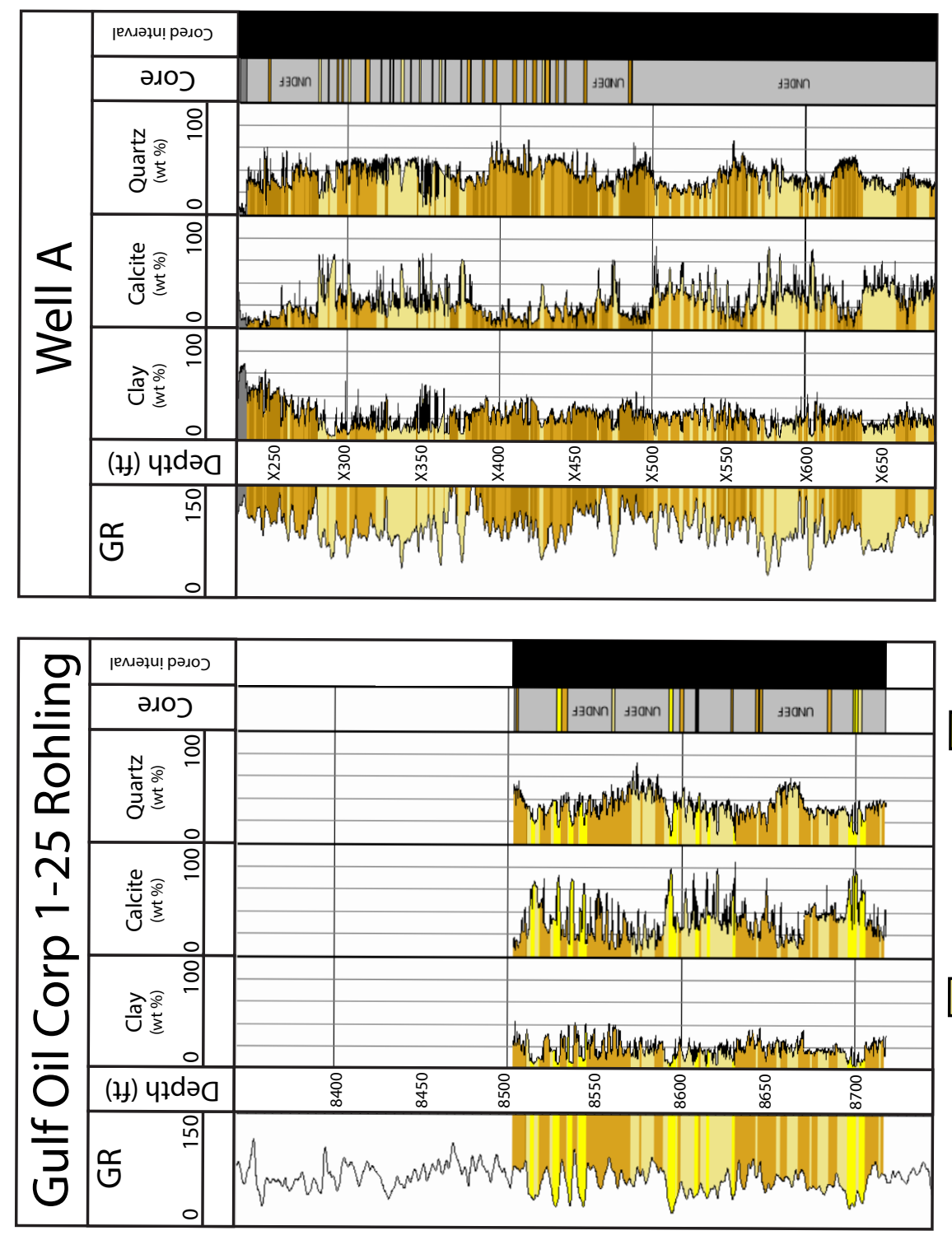

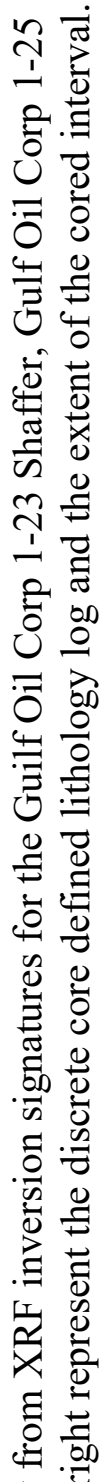

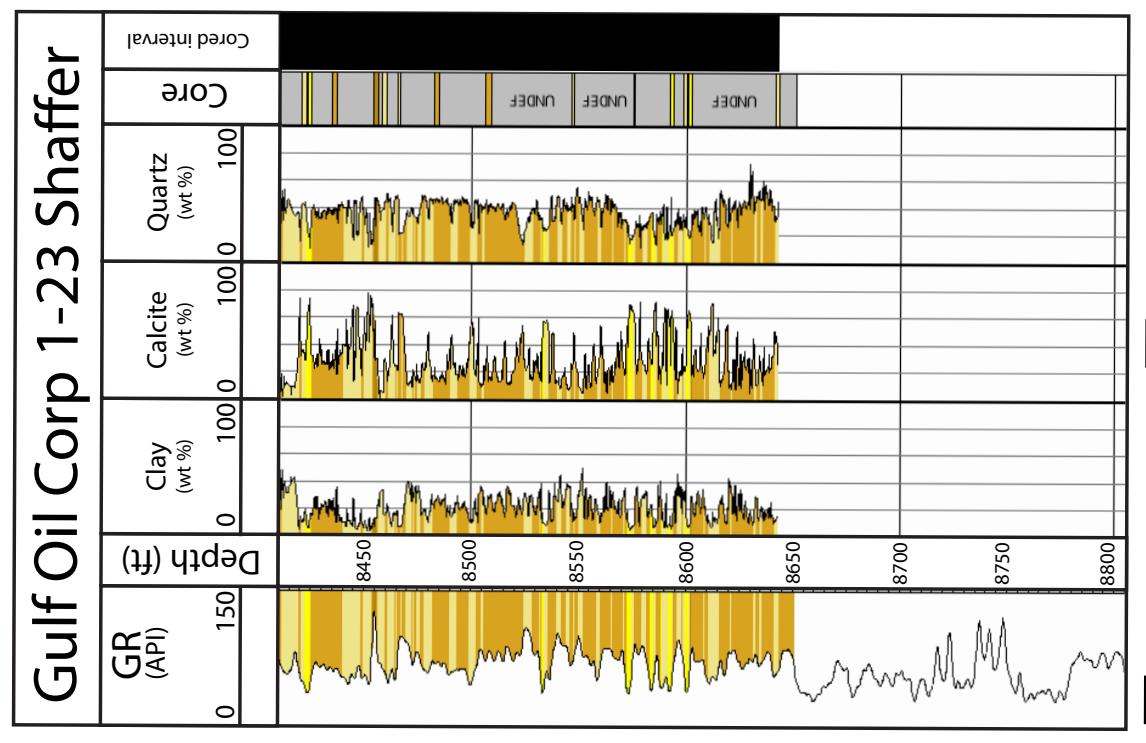

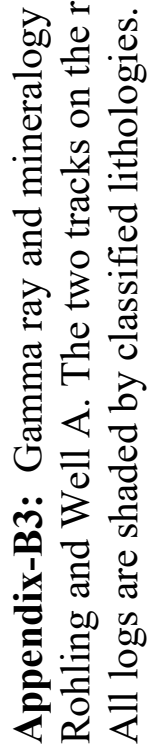




\section{APPENDIX C: Lithology and Rock Type Classification}

\begin{tabular}{|l|r|r|r|r|}
\hline \multicolumn{1}{|c|}{ ANN } & \multicolumn{4}{|c|}{ GR, NPHI, RhoB, RILD } \\
\hline Core & Mudstone & $\begin{array}{l}\text { Argillaceous } \\
\text { Siltstone }\end{array}$ & $\begin{array}{l}\text { Arg. Calc. } \\
\text { Siltstone }\end{array}$ & $\begin{array}{l}\text { Calcareous } \\
\text { Siltstone }\end{array}$ \\
\hline Mudstone & 25 & 0 & 0 & 0 \\
\hline Argillaceous Siltstone & 0 & 307 & 31 & 5 \\
\hline Arg. Calc. Siltstone & 0 & 11 & 231 & 25 \\
\hline Calcareous Siltstone & 0 & 2 & 18 & 345 \\
\hline User Accuracy & $100.0 \%$ & $95.9 \%$ & $82.5 \%$ & $92.0 \%$ \\
\hline
\end{tabular}

Overall Accuracy : $90.8 \%$

\begin{tabular}{|l|r|r|r|r|}
\hline \multicolumn{1}{|c|}{ ANN } & \multicolumn{4}{|c|}{ GR, NPHI, RhoB, RILD } \\
\hline Core & $\begin{array}{c}\text { Argillaceous } \\
\text { Siltstone }\end{array}$ & $\begin{array}{c}\text { Arg. Calc. } \\
\text { Siltstone }\end{array}$ & $\begin{array}{l}\text { Calcareous } \\
\text { Siltstone }\end{array}$ & $\begin{array}{c}\text { Silty } \\
\text { Limestone }\end{array}$ \\
\hline Argillaceous Siltstone & 0 & 0 & 0 & 0 \\
\hline Arg. Calc. Siltstone & 0 & 225 & 30 & 0 \\
\hline Calcareous Siltstone & 0 & 36 & 32 & 21 \\
\hline Silty Limestone & 0 & 11 & 5 & 134 \\
\hline User Accuracy & $0.0 \%$ & $82.7 \%$ & $47.8 \%$ & $86.5 \%$ \\
\hline
\end{tabular}

Overall Accuracy : $79.2 \%$

\begin{tabular}{|l|r|r|r|r|}
\hline \multicolumn{1}{|c|}{ ANN } & \multicolumn{4}{|c|}{ GR, NPHI, RhoB, RILD } \\
\hline \multicolumn{1}{c|}{$\begin{array}{c}\text { Argillaceous } \\
\text { Siltstone }\end{array}$} & $\begin{array}{c}\text { Arg. Calc. } \\
\text { Silstone }\end{array}$ & $\begin{array}{l}\text { Calcareous } \\
\text { Siltstone }\end{array}$ & $\begin{array}{c}\text { Silty } \\
\text { Limestone }\end{array}$ \\
\hline Argillaceous Siltstone & 38 & 3 & 8 & 0 \\
\hline Arg. Calc. Siltstone & 0 & 140 & 0 & 0 \\
\hline Calcareous Siltstone & 0 & 63 & 134 & 7 \\
\hline Silty Limestone & 0 & 0 & 0 & 97 \\
\hline User Accuracy & $100.0 \%$ & $67.9 \%$ & $94.4 \%$ & $93.3 \%$ \\
\hline
\end{tabular}

Appendix-C1: Confusion matrix of the artificial neural net (ANN) showing accuracies of the classifications for lithologies in the A) Well A, B) Gulf Oil Corp 1-23 Rohling and C) Gulf Oil Corp 1-25 Shaffer. ANN inputs include: gamma ray (GR), neutron porosity (NPHI), bulk density (RhoB) and deep resistivity (RILD). 


\begin{tabular}{|l|r|r|r|r|}
\hline \multicolumn{1}{|c|}{ ANN } & \multicolumn{4}{|c|}{ GR, NPHI, RhoB } \\
\hline Core & Mudstone & $\begin{array}{l}\text { Argillaceous } \\
\text { Siltstone }\end{array}$ & $\begin{array}{l}\text { Arg. Calc. } \\
\text { Siltstone }\end{array}$ & $\begin{array}{l}\text { Calcareous } \\
\text { Siltstone }\end{array}$ \\
\hline Mudstone & 25 & 0 & 0 & 0 \\
\hline Argillaceous Siltstone & 0 & 310 & 29 & 4 \\
\hline Arg. Calc. Siltstone & 0 & 42 & 219 & 6 \\
\hline Calcareous Siltstone & 0 & 10 & 8 & 347 \\
\hline User Accuracy & $100.0 \%$ & $85.6 \%$ & $85.6 \%$ & $97.2 \%$ \\
\hline
\end{tabular}

Overall Accuracy : $90.10 \%$

\begin{tabular}{|l|r|r|r|r|}
\hline \multicolumn{1}{|c|}{ ANN } & \multicolumn{4}{|c|}{ GR, NPHI, RhoB } \\
\hline \multicolumn{1}{c|}{ Core } & $\begin{array}{c}\text { Argillaceous } \\
\text { Siltstone }\end{array}$ & $\begin{array}{l}\text { Arg. Calc. } \\
\text { Siltstone }\end{array}$ & $\begin{array}{l}\text { Calcareous } \\
\text { Siltstone }\end{array}$ & $\begin{array}{c}\text { Silty } \\
\text { Limestone }\end{array}$ \\
\hline Argillaceous Siltstone & 0 & 0 & 0 & 0 \\
\hline Arg. Calc. Siltstone & 0 & 212 & 43 & 0 \\
\hline Calcareous Siltstone & 0 & 26 & 41 & 22 \\
\hline Silty Limestone & 0 & 8 & 8 & 134 \\
\hline User Accuracy & $0.0 \%$ & $86.2 \%$ & $44.6 \%$ & $85.9 \%$ \\
\hline
\end{tabular}

Overall Accuracy : $78.3 \%$

\begin{tabular}{|l|r|r|r|r|}
\hline \multicolumn{1}{|c|}{ ANN } & \multicolumn{4}{|c|}{ GR, NPHI, RhoB } \\
\hline Core & $\begin{array}{c}\text { Argillaceous } \\
\text { Siltstone }\end{array}$ & $\begin{array}{c}\text { Arg. Calc. } \\
\text { Silstone }\end{array}$ & $\begin{array}{l}\text { Calcareous } \\
\text { Siltstone }\end{array}$ & $\begin{array}{c}\text { Silty } \\
\text { Limestone }\end{array}$ \\
\hline Argillaceous Siltstone & 39 & 4 & 6 & 0 \\
\hline Arg. Calc. Siltstone & 0 & 140 & 0 & 0 \\
\hline Calcareous Siltstone & 0 & 77 & 122 & 53 \\
\hline Silty Limestone & 0 & 0 & 4 & $94.9 \%$ \\
\hline User Accuracy & $100.0 \%$ & $63.4 \%$ & $92.4 \%$ & 93 \\
\hline
\end{tabular}

Appendix-C2: Confusion matrix of the artificial neural net (ANN) showing accuracies of the classifications for lithologies in the A) Well A, B) Gulf Oil Corp 1-23 Rohling and C) Gulf Oil Corp 1-25 Shaffer. ANN inputs include: gamma ray (GR), neutron porosity (NPHI) and bulk density (RhoB). 


\begin{tabular}{|l|r|r|r|}
\hline A ANN & \multicolumn{3}{|c|}{ GR, NPHI, RhoB, PE } \\
\hline \multicolumn{1}{|c|}{ Core } & $\begin{array}{c}\text { Rock Type } \\
1\end{array}$ & $\begin{array}{c}\text { Rock Type } \\
2\end{array}$ & $\begin{array}{c}\text { Rock Type } \\
3\end{array}$ \\
\hline Rock Type 1 & 266 & 209 & 38 \\
\hline Rock Type 2 & 59 & 717 & 192 \\
\hline Rock Type 3 & 6 & 137 & 456 \\
\hline User Accuracy & $80.4 \%$ & $67.5 \%$ & $66.5 \%$ \\
\hline
\end{tabular}

Overall Accuracy : $69.2 \%$

\begin{tabular}{|l|r|r|r|}
\hline B ANN & \multicolumn{3}{|c|}{ GR, NPHI, RhoB, RILD } \\
\hline \multicolumn{1}{|c|}{ Core } & $\begin{array}{c}\text { Rock Type } \\
1\end{array}$ & $\begin{array}{c}\text { Rock Type } \\
2\end{array}$ & $\begin{array}{c}\text { Rock Type } \\
3\end{array}$ \\
\hline Rock Type 1 & 226 & 276 & 11 \\
\hline Rock Type 2 & 64 & 712 & 192 \\
\hline Rock Type 3 & 10 & 234 & 355 \\
\hline User Accuracy & $75.3 \%$ & $58.3 \%$ & $63.6 \%$ \\
\hline
\end{tabular}

Overall Accuracy : $62.2 \%$

\begin{tabular}{|l|r|r|r|}
\hline \multicolumn{1}{|c|}{ ANN } & \multicolumn{3}{|c|}{ GR, NPHI, RhoB } \\
\hline \multicolumn{1}{|c|}{ Core } & $\begin{array}{c}\text { Rock Type } \\
1\end{array}$ & $\begin{array}{c}\text { Rock Type } \\
2\end{array}$ & $\begin{array}{c}\text { Rock Type } \\
3\end{array}$ \\
\hline Rock Type 1 & 236 & 252 & 25 \\
\hline Rock Type 2 & 56 & 765 & 147 \\
\hline Rock Type 3 & 8 & 247 & 344 \\
\hline User Accuracy & $78.7 \%$ & $60.5 \%$ & $66.7 \%$ \\
\hline
\end{tabular}

Overall Accuracy : $64.7 \%$

Appendix-C3: Confusion matrix of the artificial neural net (ANN) showing accuracies of the classifications for rock types in Well A. ANN inputs include: A) gamma ray (GR), neutron porosity (NPHI), bulk density (RhoB) and photoelectric effect (PE), B) gamma ray (GR), neutron porosity (NPHI), bulk density (RhoB) and deep resistivity (RILD) and C) gamma ray (GR), neutron porosity (NPHI) and bulk density (RhoB). 


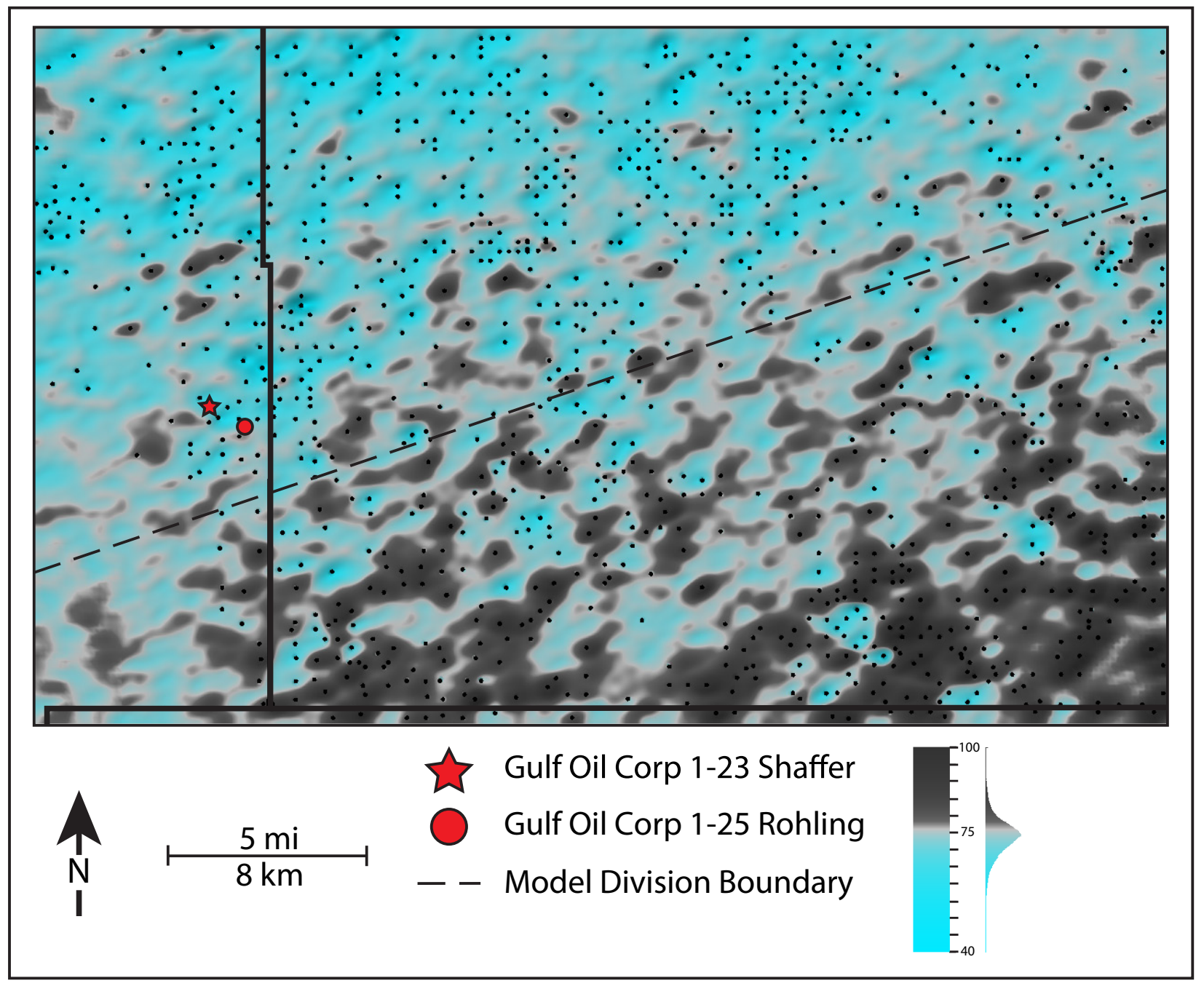

Appendix-C4: Map of the study area with an average gamma ray map as an overlay and the locations of two cored wells annotated above. The Gulf Oil Corp 1-23 Rohling and 1-25 Shaffer was cored in an area of lower average gamma ray values and Well $\mathrm{A}$ at an undisclosed location southeast was cored in an area of higher average gamma ray values. The dashed line represents where the model was divided into half based on the gamma ray trend observed. 


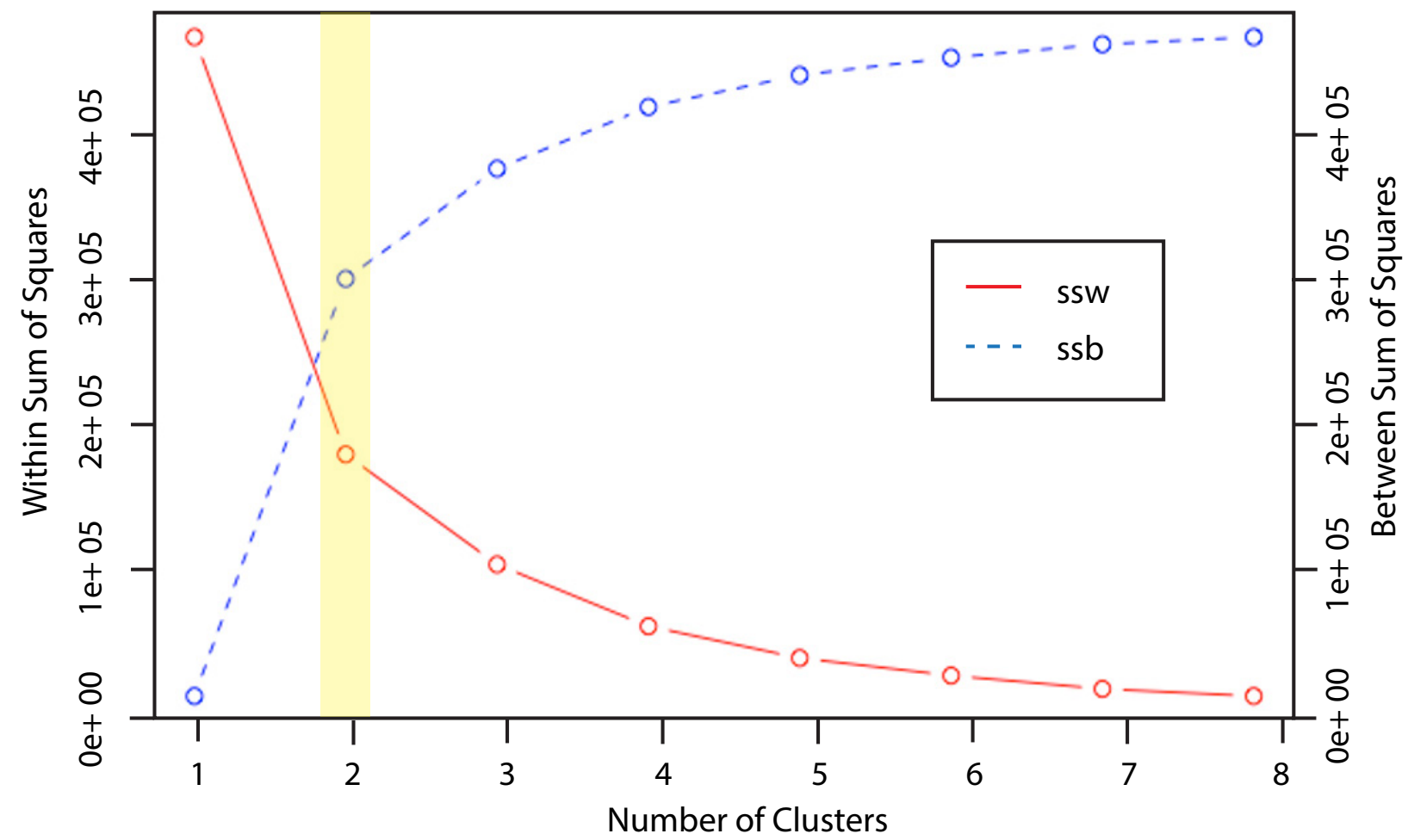

Appendix -C5: Plot of Sum-of-Squares within (SSW) and Sum-of-Squares between also known as an elbow plot. The SSW plot compares the cumulative distance of each point to its corresponding centroid as the number $\mathrm{K}$ values increase. The SSB plot compares the cumulative distance of each centroid to the global centroid in the data with increasing $\mathrm{K}$ values. Where the slope of both SSW and SSB decreases, known as the elbow, indicates the optimal number of K for the data set. 


\begin{tabular}{|c|c|c|c|c|}
\hline \multicolumn{5}{|c|}{ Variogram Parameters for Lithology Modeling ( Mudstone) } \\
\hline Zone & Major (ft) & Minor $(\mathrm{ft})$ & Vertical (ft) & $\begin{array}{c}\text { Azimuth } \\
\text { (degrees from } \mathrm{N} \text { ) }\end{array}$ \\
\hline MRMC_G & 4000 & 2000 & 5.95 & 70 \\
\hline MRMC_F & 4000 & 2000 & 4.855 & 70 \\
\hline MRMC_E & 4000 & 2000 & 5.299 & 70 \\
\hline MRMC_D & 4000 & 2000 & 5.232 & 70 \\
\hline MRMC_B & 4000 & 2000 & 5.198 & 70 \\
\hline MRMC_B10 & 4000 & 2000 & 5.176 & 70 \\
\hline MRMC_A & 4000 & 2000 & 5.209 & 70 \\
\hline \multicolumn{5}{|c|}{ Variogram Parameters for Lithology Modeling (Argillaceous Siltstone) } \\
\hline Zone & Major (ft) & Minor $(\mathrm{ft})$ & Vertical (ft) & $\begin{array}{c}\text { Azimuth } \\
\text { (degrees from } \mathrm{N} \text { ) }\end{array}$ \\
\hline MRMC_G & 4000 & 2000 & 6.99 & 70 \\
\hline MRMC_F & 4000 & 2000 & 5.392 & 70 \\
\hline MRMC_E & 4000 & 2000 & 5.052 & 70 \\
\hline MRMC_D & 4000 & 2000 & 5.071 & 70 \\
\hline MRMC_B & 4000 & 2000 & 5.215 & 70 \\
\hline MRMC_B10 & 4000 & 2000 & 5.172 & 70 \\
\hline MRMC_A & 4000 & 2000 & 5.158 & 70 \\
\hline \multicolumn{5}{|c|}{ Variogram Parameters for Lithology Modeling (Argillaceous-Calcareous Siltstone) } \\
\hline Zone & Major (ft) & Minor (ft) & Vertical (ft) & $\begin{array}{c}\text { Azimuth } \\
\text { (degrees from } \mathrm{N} \text { ) }\end{array}$ \\
\hline MRMC_G & 4000 & 2000 & 5.501 & 70 \\
\hline MRMC_F & 4000 & 2000 & 5.314 & 70 \\
\hline MRMC_E & 4000 & 2000 & 5.105 & 70 \\
\hline MRMC_D & 4000 & 2000 & 5.1 & 70 \\
\hline MRMC_B & 4000 & 2000 & 4.957 & 70 \\
\hline MRMC_B10 & 4000 & 2000 & 5.315 & 70 \\
\hline MRMC_A & 4000 & 2000 & 5.278 & 70 \\
\hline
\end{tabular}

Appendix-C6: Horizontal and vertical variogram ranges for the lithology model separated by zone. Horizontal ranges were estimated from well spacing. The vertical ranges were estimated through variography for each zone by lithology. 


\begin{tabular}{|c|c|c|c|c|}
\hline \multicolumn{5}{|c|}{ Variogram Parameters for Lithology Modeling (Calcareous Siltstone) } \\
\hline Zone & Major (ft) & Minor $(\mathrm{ft})$ & Vertical (ft) & $\begin{array}{c}\text { Azimuth } \\
\text { (degrees from } \mathrm{N} \text { ) }\end{array}$ \\
\hline MRMC_G & 4000 & 2000 & 5.767 & 70 \\
\hline MRMC_F & 4000 & 2000 & 5.217 & 70 \\
\hline MRMC_E & 4000 & 2000 & 5.18 & 70 \\
\hline MRMC_D & 4000 & 2000 & 5.239 & 70 \\
\hline MRMC_B & 4000 & 2000 & 5.269 & 70 \\
\hline MRMC_B10 & 4000 & 2000 & 5.284 & 70 \\
\hline MRMC_A & 4000 & 2000 & 5.342 & 70 \\
\hline \multicolumn{5}{|c|}{ Variogram Parameters for Lithology Modeling (Silty Limestone) } \\
\hline Zone & Major $(\mathrm{ft})$ & Minor $(\mathrm{ft})$ & Vertical (ft) & $\begin{array}{c}\text { Azimuth } \\
\text { (degrees from } \mathrm{N} \text { ) }\end{array}$ \\
\hline MRMC_G & 4000 & 2000 & 8.735 & 70 \\
\hline MRMC_F & 4000 & 2000 & 4.815 & 70 \\
\hline MRMC_E & 4000 & 2000 & 5.227 & 70 \\
\hline MRMC_D & 4000 & 2000 & 5.015 & 70 \\
\hline MRMC_B & 4000 & 2000 & 5.148 & 70 \\
\hline MRMC_B10 & 4000 & 2000 & 5.093 & 70 \\
\hline MRMC_A & 4000 & 2000 & 5.295 & 70 \\
\hline
\end{tabular}

Appendix-C6 cont'd.: Horizontal and vertical variogram ranges for the lithology model separated by zone. Horizontal ranges were estimated from well spacing. The vertical ranges were estimated through variography for each zone by lithology. 


\begin{tabular}{|c|c|c|c|c|c|}
\hline \multicolumn{6}{|c|}{ Variogram Parameters for Rock Type Modeling (Rock Type 1) } \\
\hline Zone & Lithology & Major (ft) & Minor $(\mathrm{ft})$ & Vertical (ft) & $\begin{array}{c}\text { Azimuth } \\
\text { (degrees from } \mathrm{N} \text { ) }\end{array}$ \\
\hline \multirow{5}{*}{ MRMC_G } & Mudstone & \multirow{5}{*}{3500} & \multirow{5}{*}{1750} & 4.366 & 70 \\
\hline & Argilaceous Siltstone & & & 4.51 & 70 \\
\hline & Argillaceous-Calcareous Siltstone & & & 4.51 & 70 \\
\hline & Calcareous Siltstone & & & 4.038 & 70 \\
\hline & Silty Limestone & & & 4.551 & 70 \\
\hline \multirow{5}{*}{ MRMC_F } & Mudstone & \multirow{5}{*}{3500} & \multirow{5}{*}{1750} & 4.51 & 70 \\
\hline & Argilaceous Siltstone & & & 4.51 & 70 \\
\hline & Argillaceous-Calcareous Siltstone & & & 3.976 & 70 \\
\hline & Calcareous Siltstone & & & 4.181 & 70 \\
\hline & Silty Limestone & & & 4.53 & 70 \\
\hline \multirow{5}{*}{ MRMC_E } & Mudstone & \multirow{5}{*}{3500} & \multirow{5}{*}{1750} & 4.017 & 70 \\
\hline & Argilaceous Siltstone & & & 3.997 & 70 \\
\hline & Argillaceous-Calcareous Siltstone & & & 4.51 & 70 \\
\hline & Calcareous Siltstone & & & 4.099 & 70 \\
\hline & Silty Limestone & & & 4.53 & 70 \\
\hline \multirow{5}{*}{ MRMC_D } & Mudstone & \multirow{5}{*}{3500} & \multirow{5}{*}{1750} & 4.654 & 70 \\
\hline & Argilaceous Siltstone & & & 4.017 & 70 \\
\hline & Argillaceous-Calcareous Siltstone & & & 4.366 & 70 \\
\hline & Calcareous Siltstone & & & 4.079 & 70 \\
\hline & Silty Limestone & & & 4.038 & 70 \\
\hline \multirow{5}{*}{ MRMC_B } & Mudstone & \multirow{5}{*}{3500} & \multirow{5}{*}{1750} & 4.51 & 70 \\
\hline & Argilaceous Siltstone & & & 4.53 & 70 \\
\hline & Argillaceous-Calcareous Siltstone & & & 4.079 & 70 \\
\hline & Calcareous Siltstone & & & 4.53 & 70 \\
\hline & Silty Limestone & & & 4.53 & 70 \\
\hline \multirow{5}{*}{ MRMC_B10 } & Mudstone & \multirow{5}{*}{3500} & \multirow{5}{*}{1750} & 4.489 & 70 \\
\hline & Argilaceous Siltstone & & & 4.551 & 70 \\
\hline & Argillaceous-Calcareous Siltstone & & & 3.996 & 70 \\
\hline & Calcareous Siltstone & & & 4.839 & 70 \\
\hline & Silty Limestone & & & 4.058 & 70 \\
\hline \multirow{5}{*}{ MRMC_A } & Mudstone & \multirow{5}{*}{3500} & \multirow{5}{*}{1750} & 2.148 & 70 \\
\hline & Argilaceous Siltstone & & & 4.037 & 70 \\
\hline & Argillaceous-Calcareous Siltstone & & & 3.77 & 70 \\
\hline & Calcareous Siltstone & & & 4.51 & 70 \\
\hline & Silty Limestone & & & 4.51 & 70 \\
\hline
\end{tabular}

Appendix-C7: Horizontal and vertical variogram ranges for the rock type model separated by zone. Horizontal ranges were decreased from the lithology model to capture the internal heterogeneity of the rock types within the lithologies. The vertical ranges were estimated through variography for each rock type by lithology and zone. 


\begin{tabular}{|c|c|c|c|c|c|}
\hline \multicolumn{6}{|c|}{ Variogram Parameters for Rock Type Modeling (Rock Type 2) } \\
\hline Zone & Lithology & Major (ft) & Minor $(\mathrm{ft})$ & Vertical (ft) & $\begin{array}{l}\text { Azimuth } \\
\text { (degrees from N) }\end{array}$ \\
\hline \multirow{5}{*}{ MRMC_G } & Mudstone & \multirow{5}{*}{3500} & \multirow{5}{*}{1750} & 4.428 & 70 \\
\hline & Argilaceous Siltstone & & & 4.509 & 70 \\
\hline & Argillaceous-Calcareous Siltstone & & & 4.53 & 70 \\
\hline & Calcareous Siltstone & & & 4.489 & 70 \\
\hline & Silty Limestone & & & 4.489 & 70 \\
\hline \multirow{5}{*}{ MRMC_F } & Mudstone & \multirow{5}{*}{3500} & \multirow{5}{*}{1750} & 4.51 & 70 \\
\hline & Argilaceous Siltstone & & & 4.489 & 70 \\
\hline & Argillaceous-Calcareous Siltstone & & & 3.935 & 70 \\
\hline & Calcareous Siltstone & & & 4.407 & 70 \\
\hline & Silty Limestone & & & 4.51 & 70 \\
\hline \multirow{5}{*}{ MRMC_E } & Mudstone & \multirow{5}{*}{3500} & \multirow{5}{*}{1750} & 3.996 & 70 \\
\hline & Argilaceous Siltstone & & & 3.524 & 70 \\
\hline & Argillaceous-Calcareous Siltstone & & & 4.469 & 70 \\
\hline & Calcareous Siltstone & & & 4.469 & 70 \\
\hline & Silty Limestone & & & 4.51 & 70 \\
\hline \multirow{5}{*}{ MRMC_D } & Mudstone & \multirow{5}{*}{3500} & \multirow{5}{*}{1750} & 4.53 & 70 \\
\hline & Argilaceous Siltstone & & & 4.551 & 70 \\
\hline & Argillaceous-Calcareous Siltstone & & & 3.976 & 70 \\
\hline & Calcareous Siltstone & & & 4.058 & 70 \\
\hline & Silty Limestone & & & 3.997 & 70 \\
\hline \multirow{5}{*}{ MRMC_B } & Mudstone & \multirow{5}{*}{3500} & \multirow{5}{*}{1750} & 4.489 & 70 \\
\hline & Argilaceous Siltstone & & & 3.873 & 70 \\
\hline & Argillaceous-Calcareous Siltstone & & & 3.771 & 70 \\
\hline & Calcareous Siltstone & & & 3.935 & 70 \\
\hline & Silty Limestone & & & 3.79 & 70 \\
\hline \multirow{5}{*}{ MRMC_B10 } & Mudstone & \multirow{5}{*}{3500} & \multirow{5}{*}{1750} & 4.51 & 70 \\
\hline & Argilaceous Siltstone & & & 4.51 & 70 \\
\hline & Argillaceous-Calcareous Siltstone & & & 4.222 & 70 \\
\hline & Calcareous Siltstone & & & 4.181 & 70 \\
\hline & Silty Limestone & & & 4.53 & 70 \\
\hline \multirow{5}{*}{ MRMC_A } & Mudstone & \multirow{5}{*}{3500} & \multirow{5}{*}{1750} & 4.099 & 70 \\
\hline & Argilaceous Siltstone & & & 3.955 & 70 \\
\hline & Argillaceous-Calcareous Siltstone & & & 4.078 & 70 \\
\hline & Calcareous Siltstone & & & 4.099 & 70 \\
\hline & Silty Limestone & & & 3.976 & 70 \\
\hline
\end{tabular}

Appendix-C7 cont'd.: Horizontal and vertical variogram ranges for the rock type model separated by zone. Horizontal ranges were decreased from the lithology model to capture the internal heterogeneity of the rock types within the lithologies. The vertical ranges were estimated through variography for each rock type by lithology and zone. 


\begin{tabular}{|c|c|c|c|c|c|}
\hline & Variogram Parar & or Rock Type & ing (Rock Ty & & \\
\hline Zone & Lithology & Major (ft) & Minor $(\mathrm{ft})$ & Vertical (ft) & $\begin{array}{l}\text { Azimuth } \\
\text { (degrees from } \mathrm{N} \text { ) }\end{array}$ \\
\hline \multirow{5}{*}{ MRMC_G } & Mudstone & \multirow{5}{*}{3500} & \multirow{5}{*}{1750} & 4.387 & 70 \\
\hline & Argilaceous Siltstone & & & 3.995 & 70 \\
\hline & Argillaceous-Calcareous Siltstone & & & 4.51 & 70 \\
\hline & Calcareous Siltstone & & & 4.53 & 70 \\
\hline & Silty Limestone & & & 4.469 & 70 \\
\hline \multirow{5}{*}{ MRMC_F } & Mudstone & \multirow{5}{*}{3500} & \multirow{5}{*}{1750} & 4.386 & 70 \\
\hline & Argilaceous Siltstone & & & 4.51 & 70 \\
\hline & Argillaceous-Calcareous Siltstone & & & 4.51 & 70 \\
\hline & Calcareous Siltstone & & & 4.489 & 70 \\
\hline & Silty Limestone & & & 4.53 & 70 \\
\hline \multirow{5}{*}{ MRMC_E } & Mudstone & \multirow{5}{*}{3500} & \multirow{5}{*}{1750} & 4.41 & 70 \\
\hline & Argilaceous Siltstone & & & 4.325 & 70 \\
\hline & Argillaceous-Calcareous Siltstone & & & 4.469 & 70 \\
\hline & Calcareous Siltstone & & & 4.51 & 70 \\
\hline & Silty Limestone & & & 4.407 & 70 \\
\hline \multirow{5}{*}{ MRMC_D } & Mudstone & \multirow{5}{*}{3500} & \multirow{5}{*}{1750} & 4.017 & 70 \\
\hline & Argilaceous Siltstone & & & 4.51 & 70 \\
\hline & Argillaceous-Calcareous Siltstone & & & 4.099 & 70 \\
\hline & Calcareous Siltstone & & & 3.956 & 70 \\
\hline & Silty Limestone & & & 4.53 & 70 \\
\hline \multirow{5}{*}{ MRMC_B } & Mudstone & \multirow{5}{*}{3500} & \multirow{5}{*}{1750} & 3.523 & 70 \\
\hline & Argilaceous Siltstone & & & 4.2 & 70 \\
\hline & Argillaceous-Calcareous Siltstone & & & 3.935 & 70 \\
\hline & Calcareous Siltstone & & & 4.14 & 70 \\
\hline & Silty Limestone & & & 3.996 & 70 \\
\hline \multirow{5}{*}{ MRMC_B10 } & Mudstone & \multirow{5}{*}{3500} & \multirow{5}{*}{1750} & 4.51 & 70 \\
\hline & Argilaceous Siltstone & & & 3.997 & 70 \\
\hline & Argillaceous-Calcareous Siltstone & & & 4.51 & 70 \\
\hline & Calcareous Siltstone & & & 4.53 & 70 \\
\hline & Silty Limestone & & & 4.058 & 70 \\
\hline \multirow{5}{*}{ MRMC_A } & Mudstone & \multirow{5}{*}{3500} & \multirow{5}{*}{1750} & 4.038 & 70 \\
\hline & Argilaceous Siltstone & & & 3.997 & 70 \\
\hline & Argillaceous-Calcareous Siltstone & & & 3.976 & 70 \\
\hline & Calcareous Siltstone & & & 4.448 & 70 \\
\hline & Silty Limestone & & & 4.058 & 70 \\
\hline
\end{tabular}

Appendix-C7 cont'd.: Horizontal and vertical variogram ranges for the rock type model separated by zone. Horizontal ranges were decreased from the lithology model to capture the internal heterogeneity of the rock types within the lithologies. The vertical ranges were estimated through variography for each rock type by lithology and zone. 
Variogram Parameters for Porosity Modeling ( Rock Type 1)

\begin{tabular}{|c|r|r|r|r|}
\hline Zone & \multicolumn{1}{|c|}{ Major $(\mathrm{ft})$} & \multicolumn{1}{c|}{ Minor (ft) } & \multicolumn{1}{c|}{ Vertical (ft) } & \multicolumn{1}{c|}{$\begin{array}{c}\text { Azimuth } \\
\text { (degrees from N) }\end{array}$} \\
\hline MRMC_G & 3000 & 1500 & 3.348 & 70 \\
\hline MRMC_F & 3000 & 1500 & 2.083 & 70 \\
\hline MRMC_E & 3000 & 1500 & 2.601 & 70 \\
\hline MRMC_D & 3000 & 1500 & 2.402 & 70 \\
\hline MRMC_B & 3000 & 1500 & 2.386 & 70 \\
\hline MRMC_B10 & 3000 & 1500 & 2.185 & 70 \\
\hline MRMC_A & 3000 & 1500 & 2.088 & \\
\hline
\end{tabular}

Variogram Parameters for Porosity Modeling ( Rock Type 2)

\begin{tabular}{|c|r|r|r|r|}
\hline Zone & \multicolumn{1}{|c|}{ Major (ft) } & \multicolumn{1}{c|}{ Minor (ft) } & \multicolumn{1}{c|}{ Vertical (ft) } & $\begin{array}{c}\text { Azimuth } \\
\text { (degrees from N) }\end{array}$ \\
\hline MRMC_G & 3000 & 1500 & 2.469 & 70 \\
\hline MRMC_F & 3000 & 1500 & 2.489 & 70 \\
\hline MRMC_E & 3000 & 1500 & 3.005 & 70 \\
\hline MRMC_D & 3000 & 1500 & 2.573 & 70 \\
\hline MRMC_B & 3000 & 1500 & 2.281 & 70 \\
\hline MRMC_B10 & 3000 & 1500 & 2.458 & 70 \\
\hline MRMC_A & 3000 & 1500 & 2.754 & 70 \\
\hline
\end{tabular}

\begin{tabular}{|c|r|r|r|r|}
\hline \multicolumn{5}{|c|}{ Variogram Parameters for Porosity Modeling (Rock Type 3) } \\
\hline Zone & \multicolumn{1}{|c|}{ Major (ft) } & \multicolumn{1}{c|}{ Minor (ft) } & \multicolumn{1}{c|}{ Vertical (ft) } & \multicolumn{1}{c|}{$\begin{array}{c}\text { Azimuth } \\
\text { (degrees from N) }\end{array}$} \\
\hline MRMC_G & 3000 & 1500 & 2.912 & 70 \\
\hline MRMC_F & 3000 & 1500 & 2.518 & 70 \\
\hline MRMC_E & 3000 & 1500 & 2.512 & 70 \\
\hline MRMC_D & 3000 & 1500 & 2.553 & 70 \\
\hline MRMC_B & 3000 & 1500 & 2.405 & 70 \\
\hline MRMC_B10 & 3000 & 1500 & 2.5 & 70 \\
\hline MRMC_A & 3000 & 1500 & 2.424 & 70 \\
\hline
\end{tabular}

Appendix-C8: Horizontal and vertical variogram ranges for the total porosity model separated by zone and rock type. Horizontal ranges were decreased from the rock type model to capture the internal heterogeneity of total porosity within the rock types. The vertical ranges were estimated through variography for each zone by rock type. 


\begin{tabular}{|c|c|c|c|c|}
\hline \multicolumn{5}{|c|}{ Variogram Parameters for Water Saturation Modeling ( Rock Type 1) } \\
\hline Zone & Major (ft) & Minor (ft) & Vertical (ft) & $\begin{array}{c}\text { Azimuth } \\
\text { (degrees from } \mathrm{N} \text { ) }\end{array}$ \\
\hline MRMC_G & 3000 & 1500 & 3.407 & 70 \\
\hline MRMC_F & 3000 & 1500 & 3.475 & 70 \\
\hline MRMC_E & 3000 & 1500 & 3.475 & 70 \\
\hline MRMC_D & 3000 & 1500 & 3.316 & 70 \\
\hline MRMC_B & 3000 & 1500 & 3.158 & 70 \\
\hline MRMC_B10 & 3000 & 1500 & 3.498 & 70 \\
\hline MRMC_A & 3000 & 1500 & 3.543 & 70 \\
\hline \multicolumn{5}{|c|}{ Variogram Parameters for Water Saturation Modeling ( Rock Type 2) } \\
\hline Zone & Major (ft) & Minor (ft) & Vertical (ft) & $\begin{array}{c}\text { Azimuth } \\
\text { (degrees from } \mathrm{N} \text { ) }\end{array}$ \\
\hline MRMC_G & 3000 & 1500 & 3.521 & 70 \\
\hline MRMC_F & 3000 & 1500 & 3.498 & 70 \\
\hline MRMC_E & 3000 & 1500 & 3.271 & 70 \\
\hline MRMC_D & 3000 & 1500 & 3.339 & 70 \\
\hline MRMC_B & 3000 & 1500 & 3.43 & 70 \\
\hline MRMC_B10 & 3000 & 1500 & 3.521 & 70 \\
\hline MRMC_A & 3000 & 1500 & 3.407 & 70 \\
\hline \multicolumn{5}{|c|}{ Variogram Parameters for Water Saturation Modeling ( Rock Type 3) } \\
\hline Zone & Major (ft) & Minor $(\mathrm{ft})$ & Vertical (ft) & $\begin{array}{c}\text { Azimuth } \\
\text { (degrees from } \mathrm{N} \text { ) }\end{array}$ \\
\hline MRMC_G & 3000 & 1500 & 3.589 & 70 \\
\hline MRMC_F & 3000 & 1500 & 3.521 & 70 \\
\hline MRMC_E & 3000 & 1500 & 3.453 & 70 \\
\hline MRMC_D & 3000 & 1500 & 3.385 & 70 \\
\hline MRMC_B & 3000 & 1500 & 2.569 & 70 \\
\hline MRMC_B10 & 3000 & 1500 & 3.475 & 70 \\
\hline MRMC_A & 3000 & 1500 & 3.475 & 70 \\
\hline
\end{tabular}

Appendix-C9: Horizontal and vertical variogram ranges for the water saturation model separated by zone and rock type. Horizontal ranges were decreased from the rock type model to capture the internal heterogeneity of water saturation within the rock types. The vertical ranges were estimated through variography for each zone by rock type. 

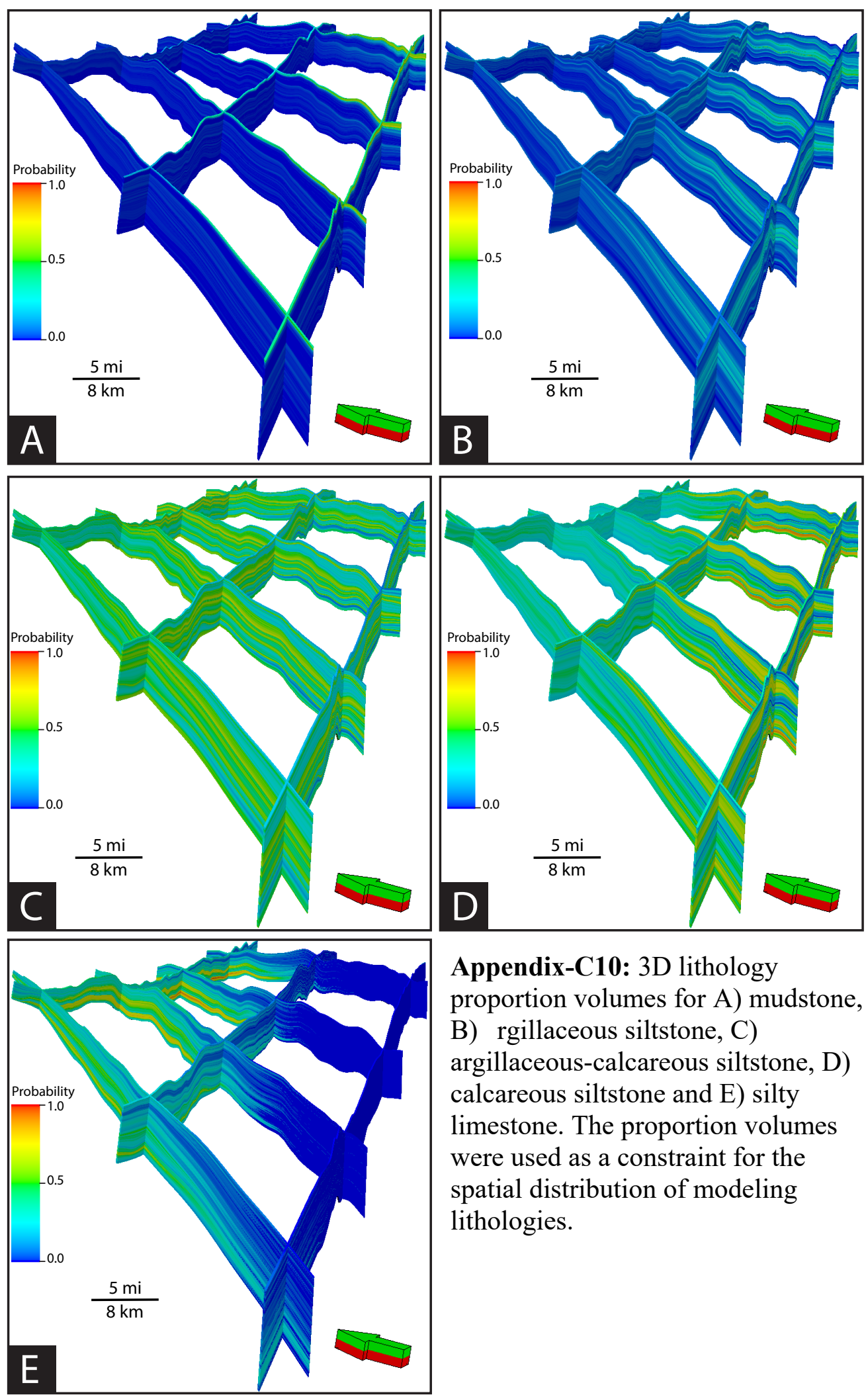

Appendix-C10: 3D lithology

proportion volumes for A) mudstone, B) rgillaceous siltstone, $\mathrm{C}$ ) argillaceous-calcareous siltstone, D) calcareous siltstone and E) silty limestone. The proportion volumes were used as a constraint for the spatial distribution of modeling lithologies. 


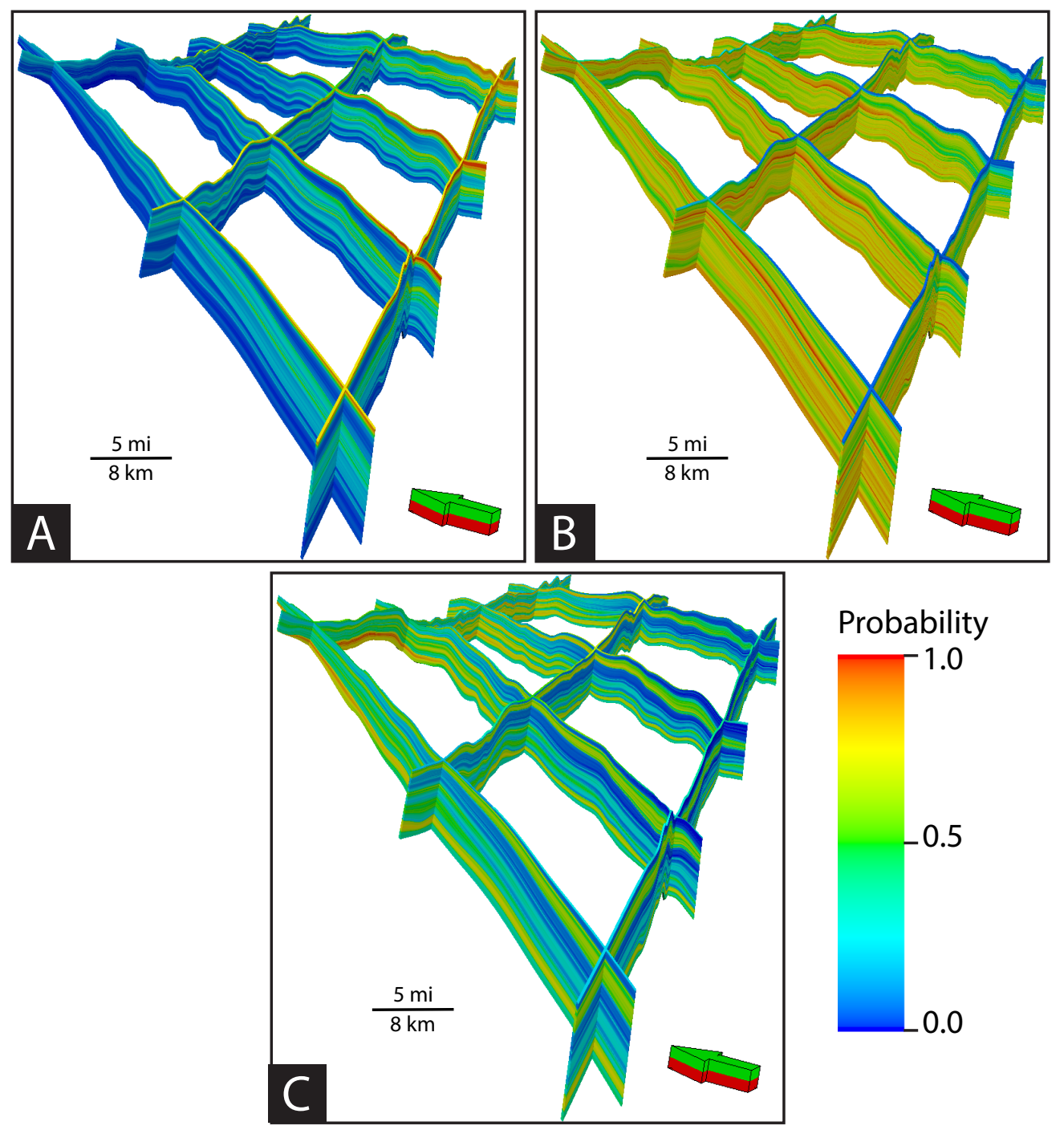

Appendix-C11: 3D rock type proportion volumes for A) rock type 1, B) rock type 2 and $C$ ) rock type 3 . The proportion volumes were used as a constraint for the spatial distribution of modeling lithologies. 
APPENDIX D: Volumetric Analysis

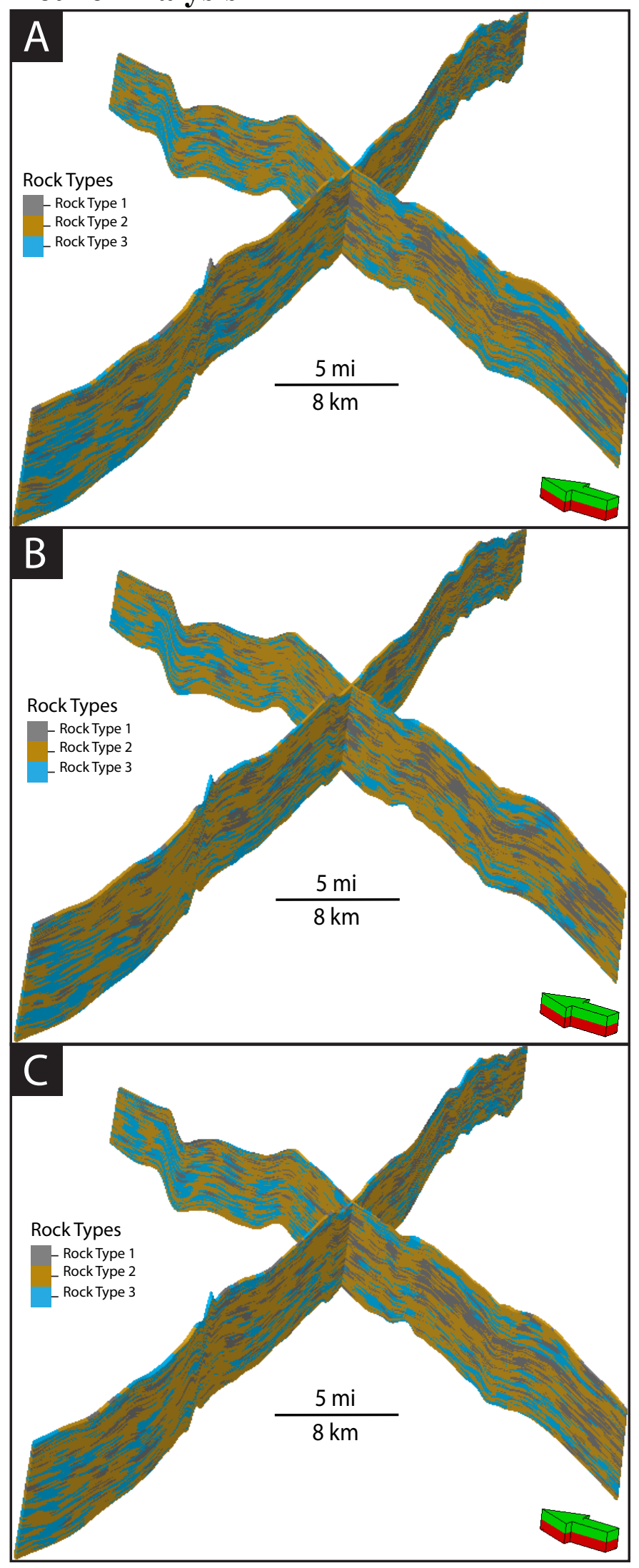


Appendix-D1: Northwest-southeast and northeast-southwest transects through the A) P10, B) P50 and C) P90 rock type models. The P10 model consisted of $23 \%$ rock type $1,50.8 \%$ rock type 2 and $26.2 \%$ rock type 3 . The P50 model changed in rock type 2 percent to $50.7 \%$ with rock types 1 and 3 remaining the same. The P90 model had an increase in rock type 1 to $23.2 \%, 50.6 \%$ rock type 2 and $26.2 \%$ rock type 3 . 

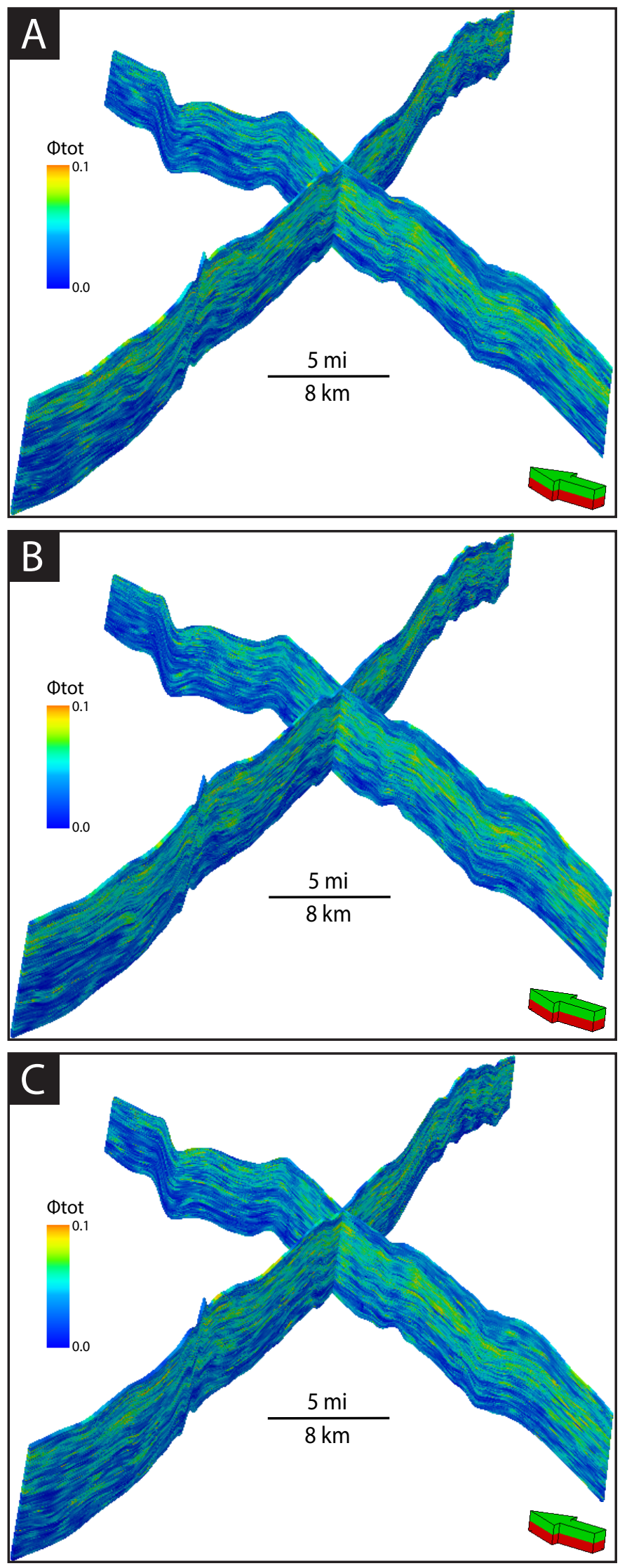
Appendix-D2: Northwest-southeast and northeast-southwest transects through the A) P10, B) P50 and C) P90 total porosity models. The mean total porosity for all 3 models remained approximately $4.3 \%$. 

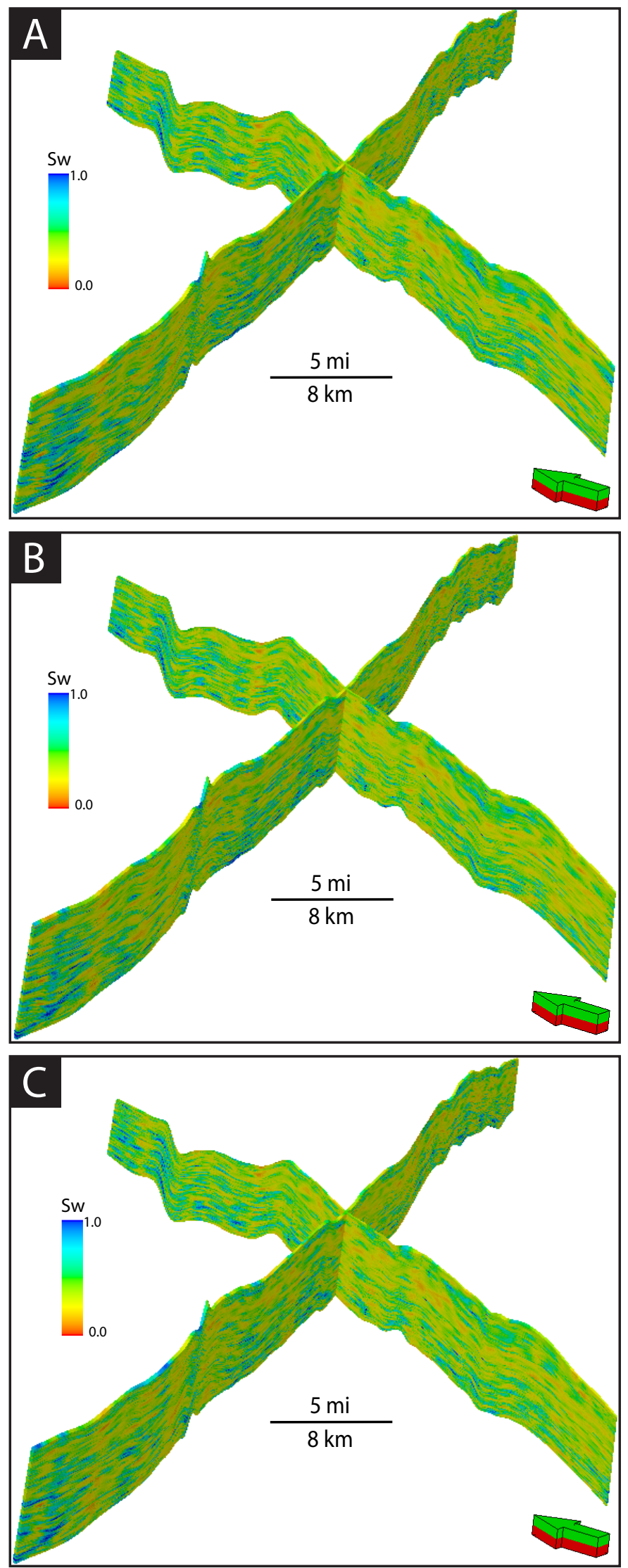
Appendix-D3: Northwest-southeast and northeast-southwest transects through the A) P10, B) P50 and C) P90 water saturation models. The mean water saturation for all 3 models remained approximately $41 \%$. 

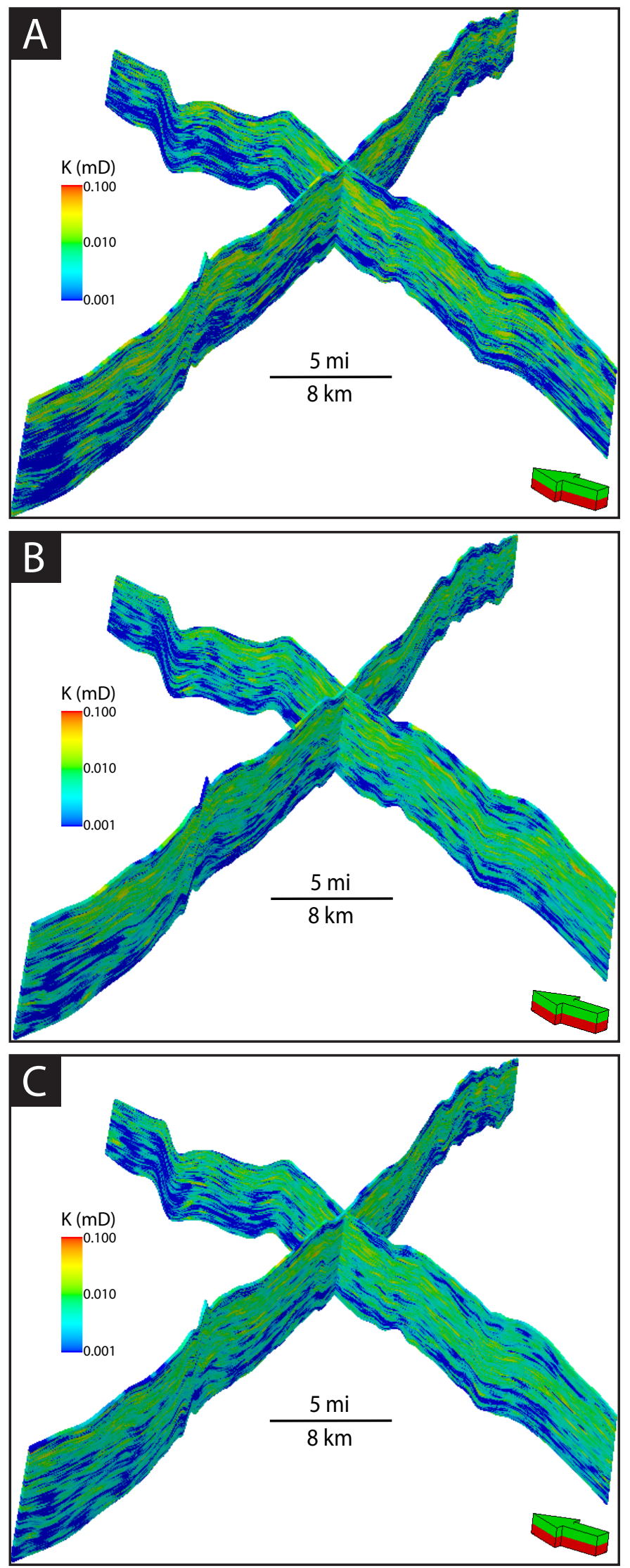
Appendix-D4: Northwest-southeast and northeast-southwest transects through the A) P10, B) P50 and C) P90 permeability models. The mean permeability for the P10, P50 and P90 models were approximately $5.6 \mu \mathrm{D}, 4.5 \mu \mathrm{D}$ and $4.5 \mu \mathrm{D}$ respectively. 

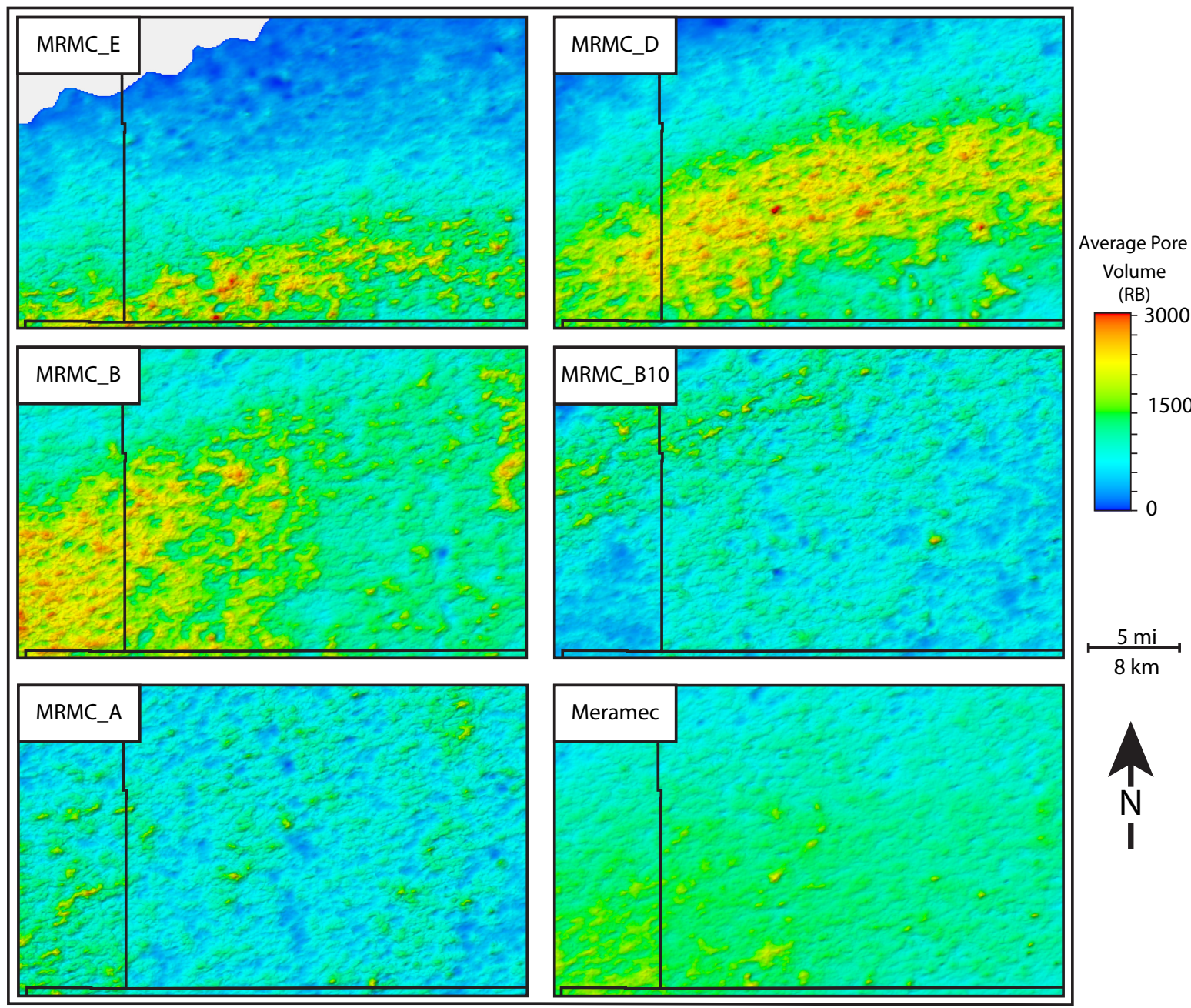

$\stackrel{5 \mathrm{mi}}{\stackrel{2 \mathrm{~km}}{\longmapsto}}$

Appendix-D5: Average P10 pore volume maps for the Meramec A, B10, B, D, E and these intervals combined. 

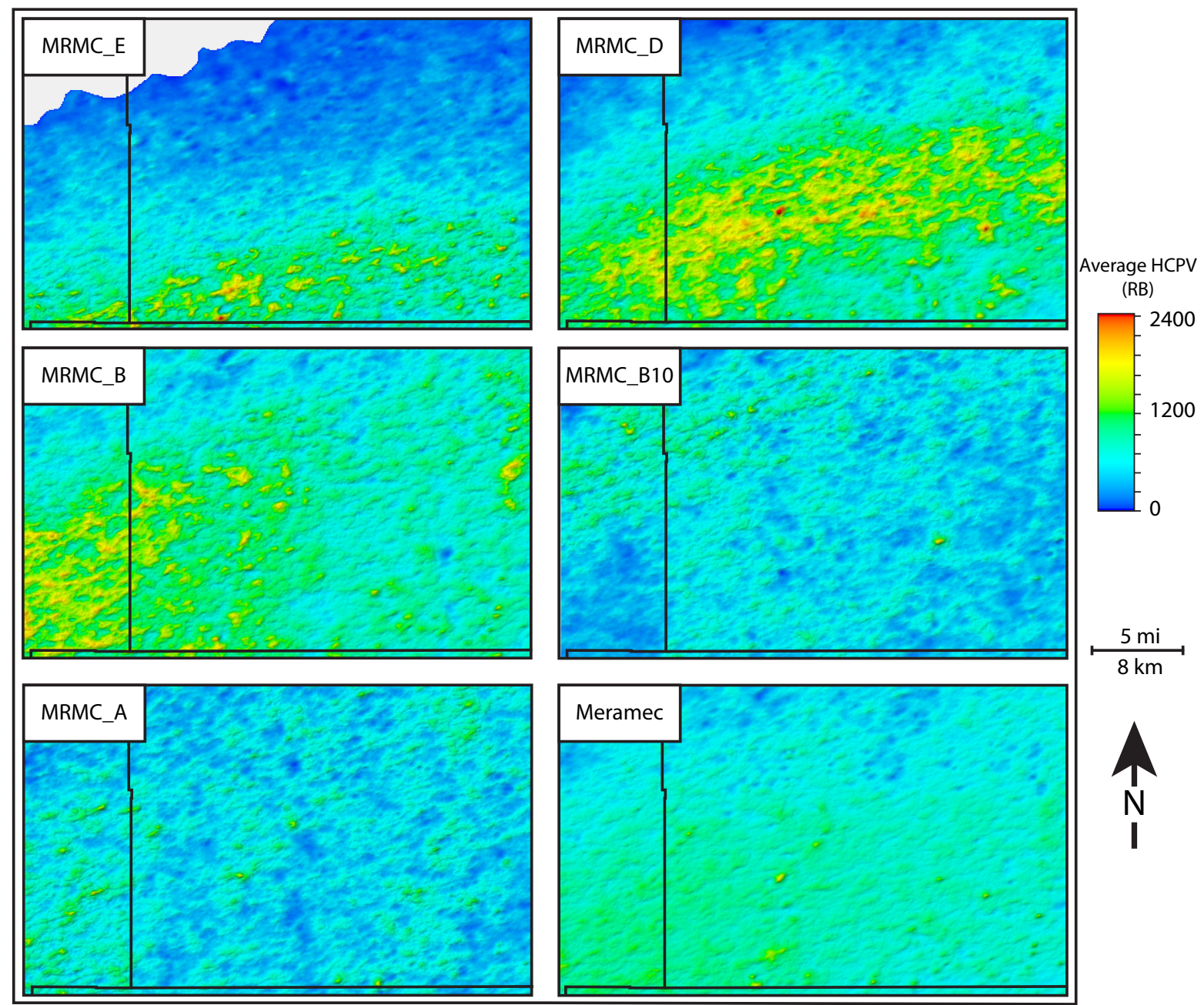

Appendix-D6: Average P10 hydrocarbon pore volume maps for the Meramec A, B10, B, $\mathrm{D}, \mathrm{E}$ and these intervals combined. 


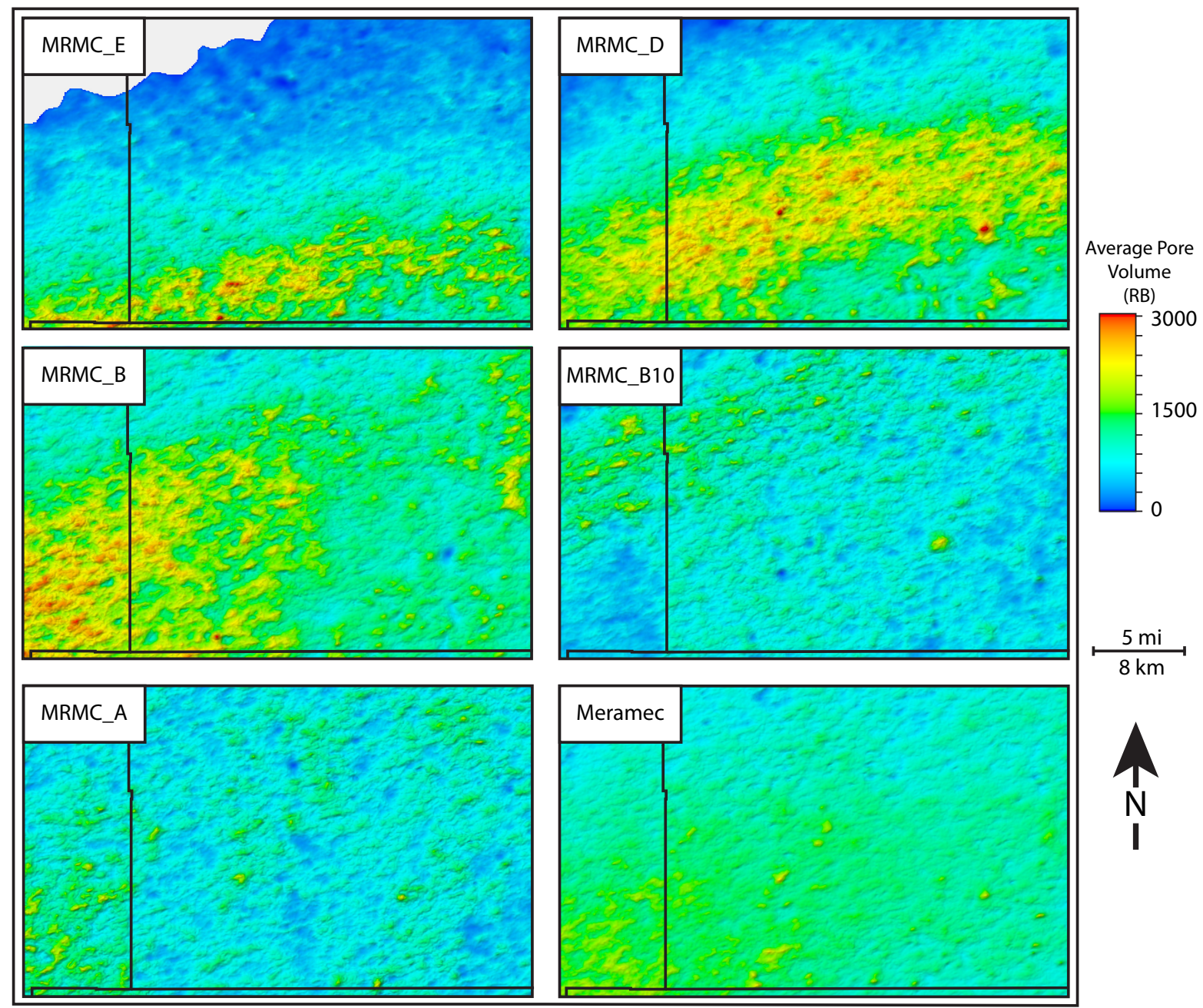

Appendix-D7: Average P50 pore volume maps for the Meramec A, B10, B, D, E and these intervals combined. 

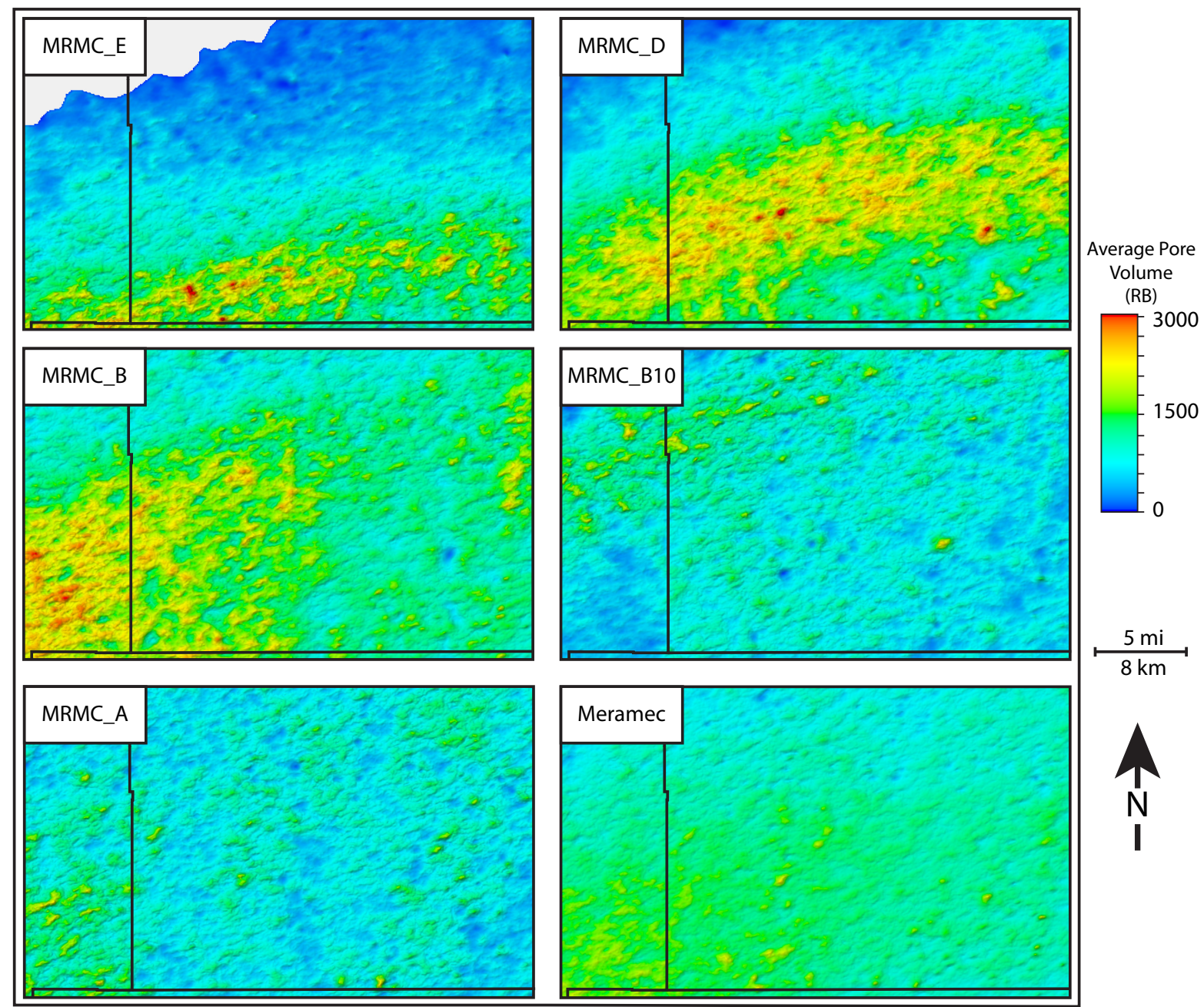

Appendix-D8: Average P90 pore volume maps for the Meramec A, B10, B, D, E and these intervals combined. 


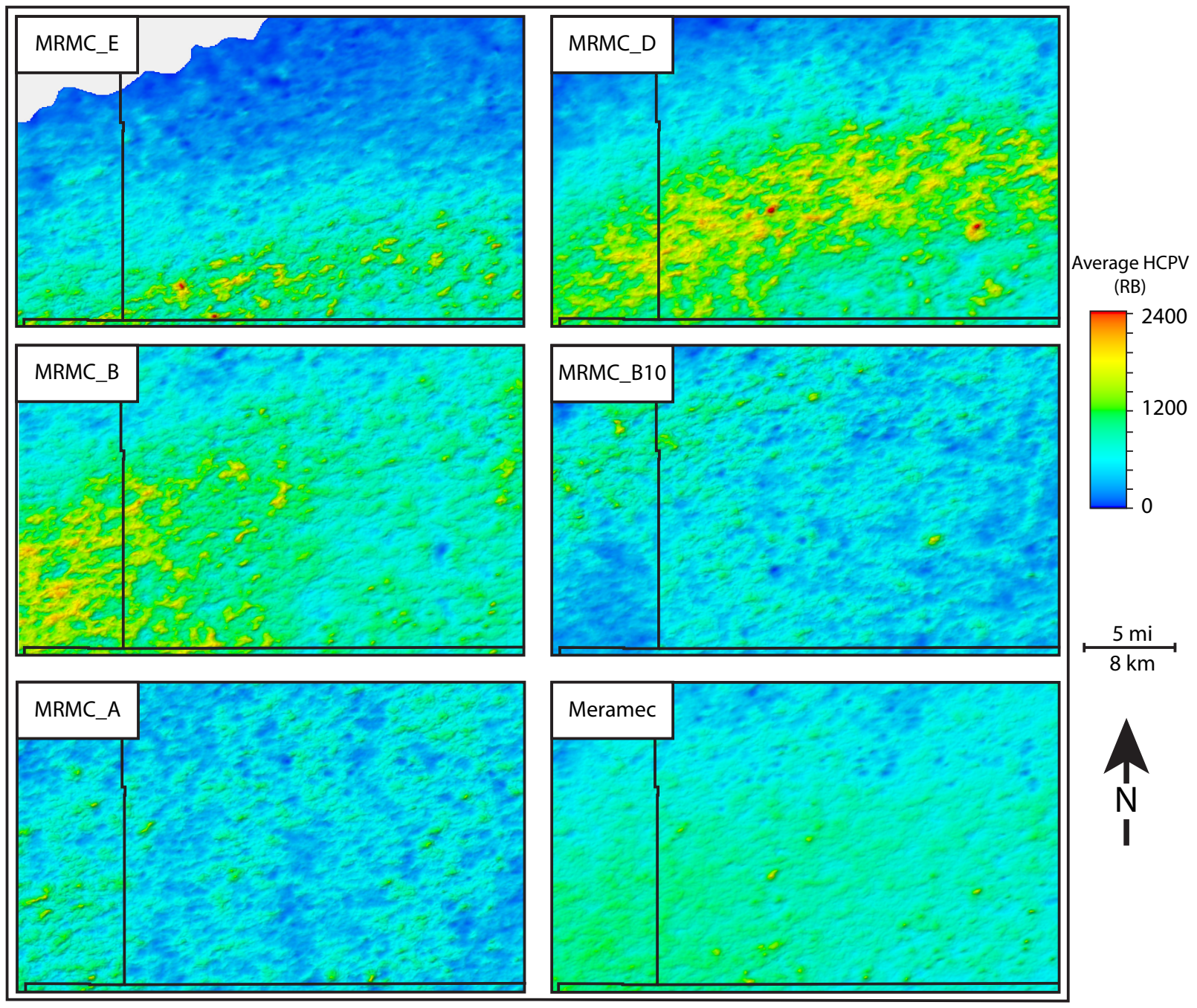

Appendix-D9: Average P90 hydrocarbon pore volume maps for the Meramec A, B10, B, D, E and these intervals combined. 


\section{APPENDIX E: Production Analysis}
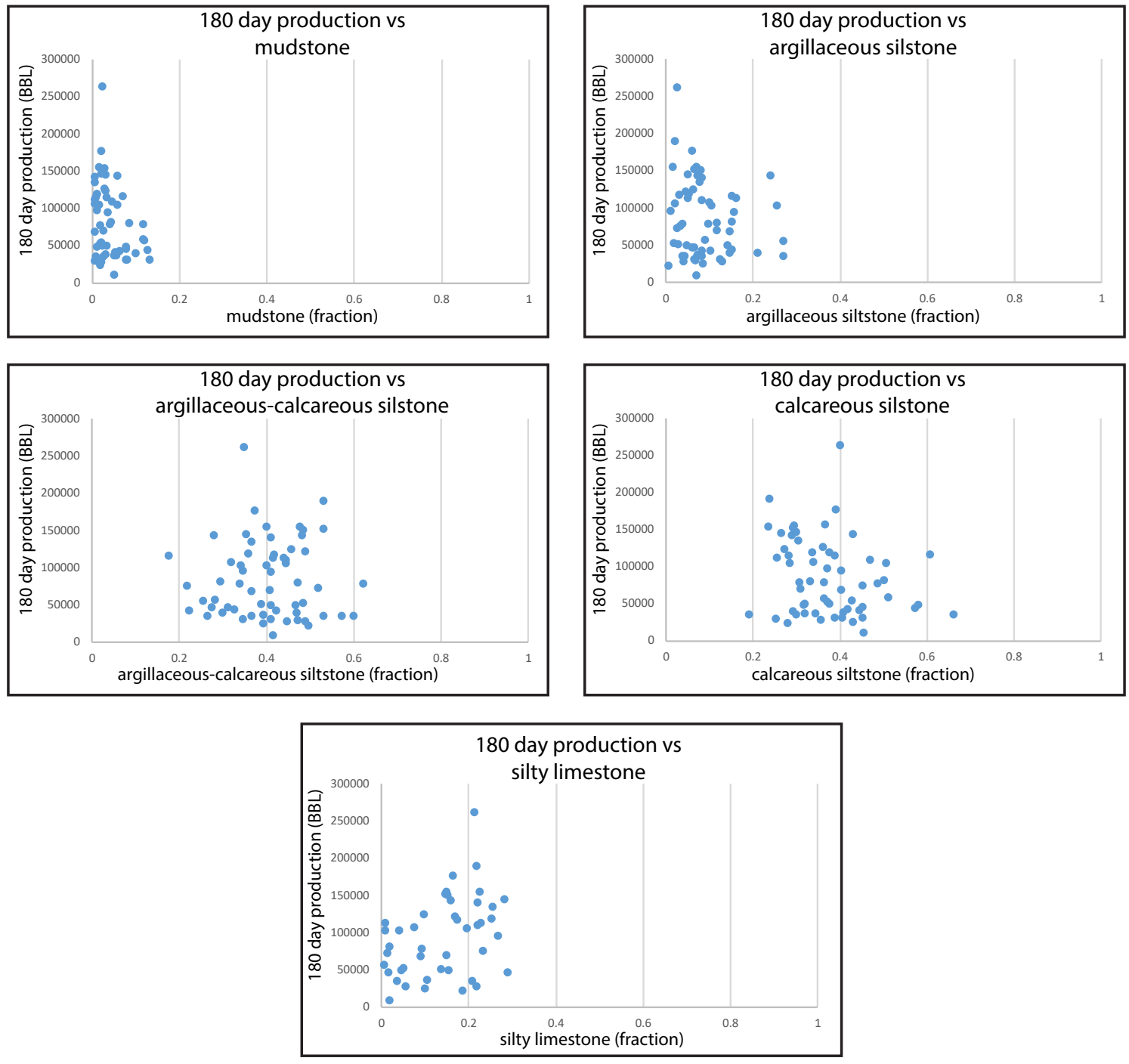

Appendix-E1: Cross-plots of 180-day cumulative production versus lithology fractions extracted along the lateral. 

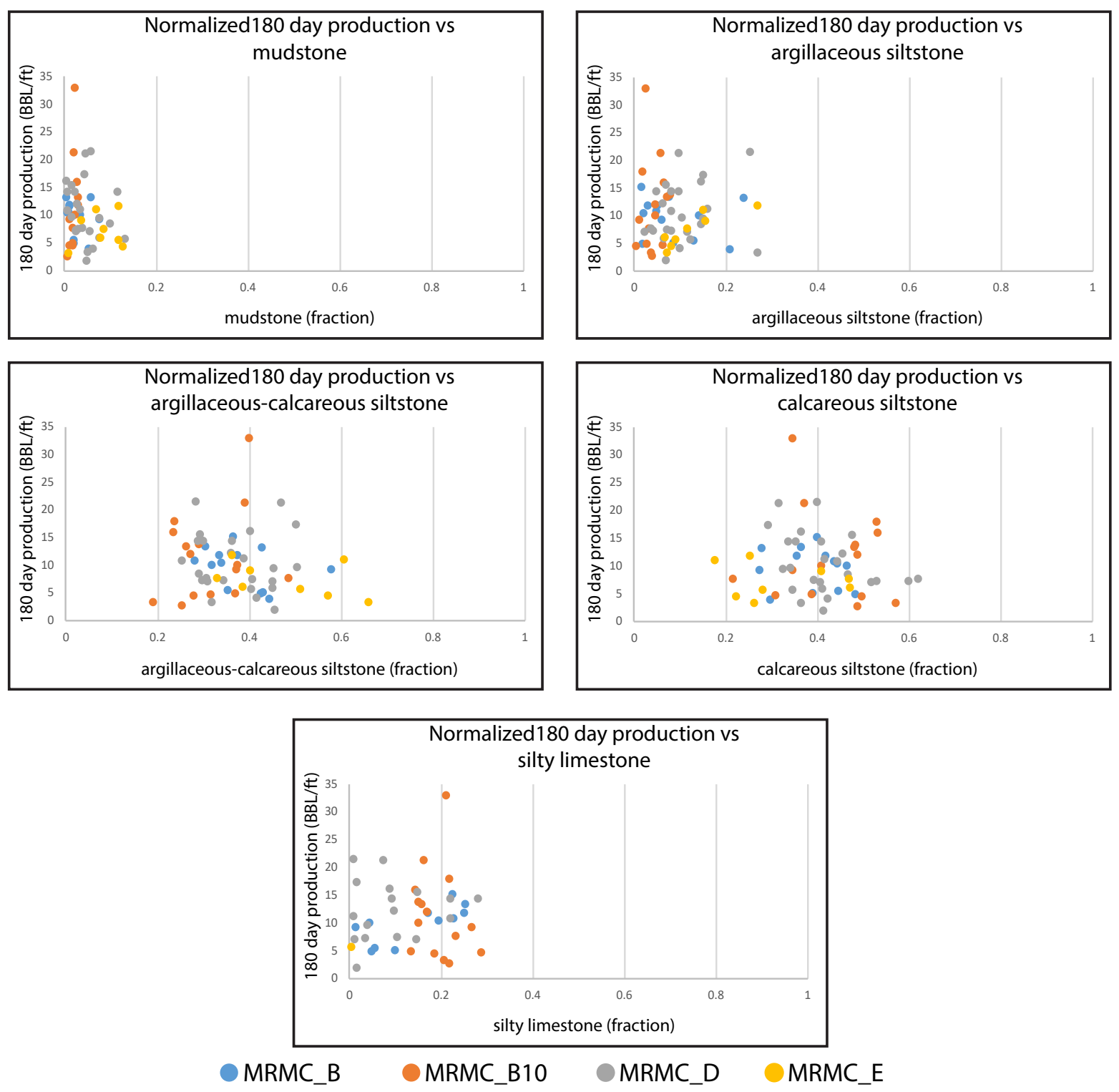

Appendix-E2: Cross-plots of 180-day cumulative production versus lithology fractions extracted along the lateral. The production has been normalized by dividing the cumulative production by the lateral length of the well. 

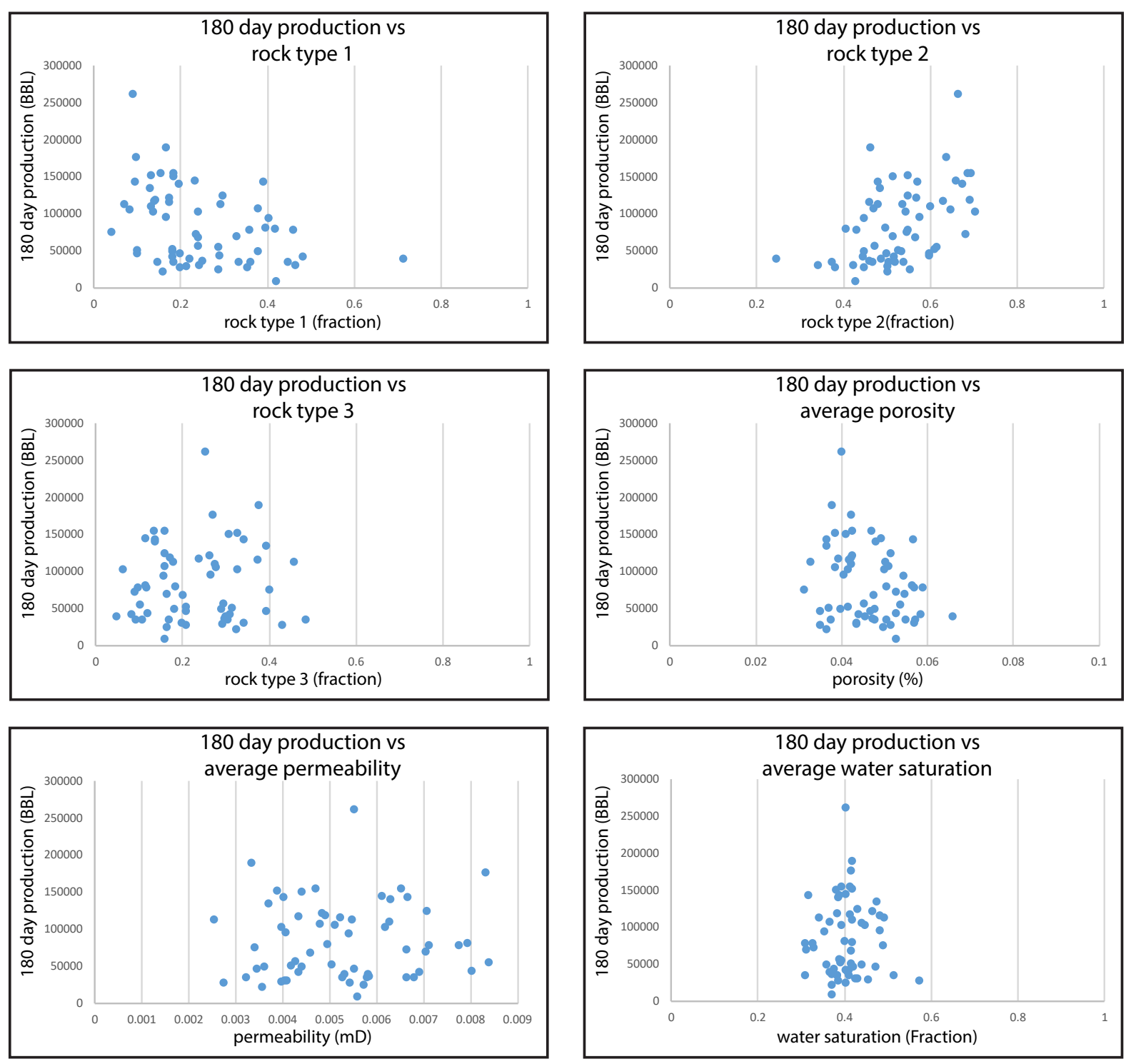

Appendix-E3: Cross-plots of 180-day cumulative production versus rock type fractions and averaged petrophysical properties extracted along the lateral. 

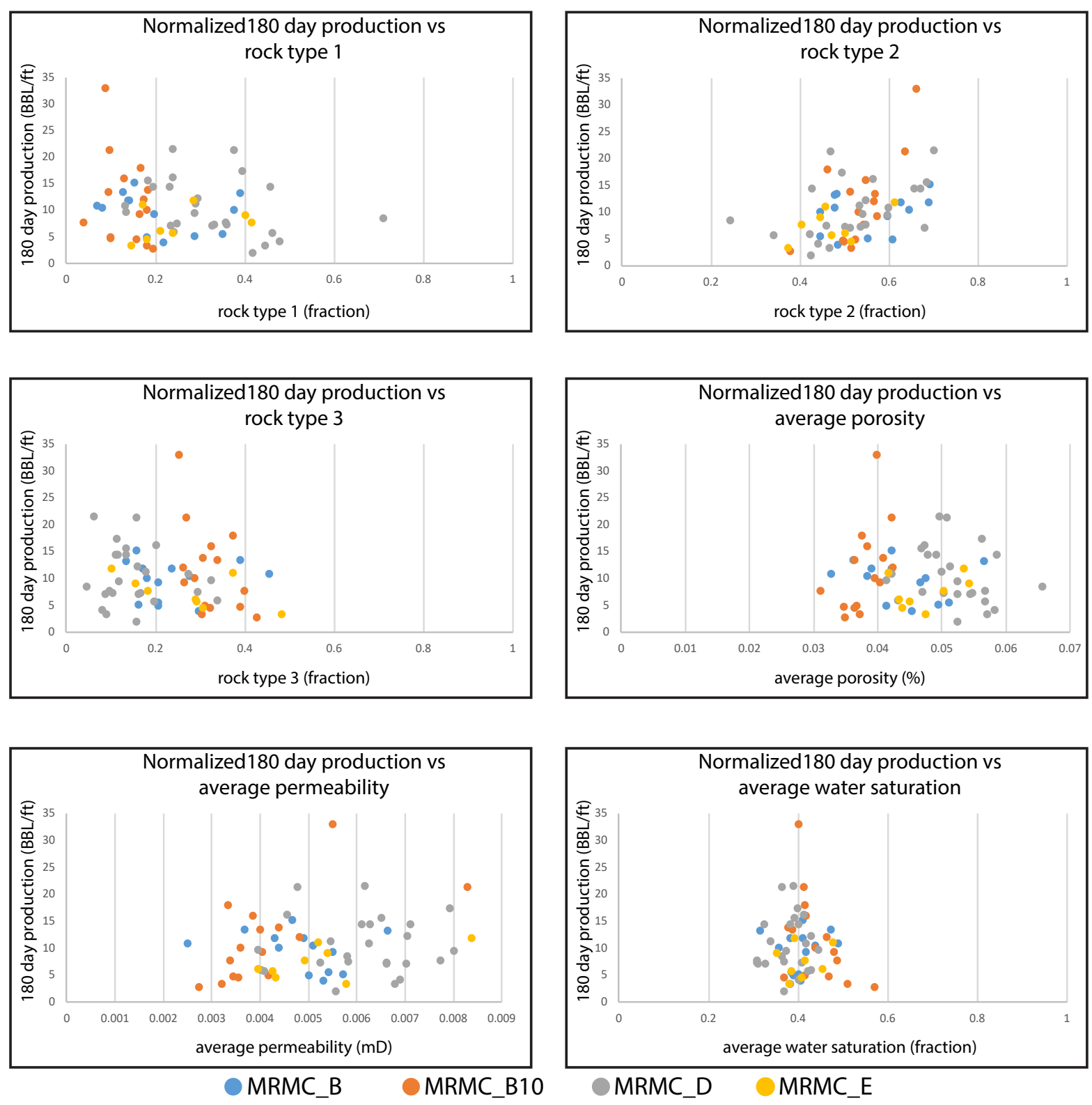

Appendix-E4: Cross-plots of 180-day cumulative production versus rock type fractions and averaged petrophysical properties extracted along the lateral. The production has been normalized by dividing the cumulative production by the lateral length of the well. 

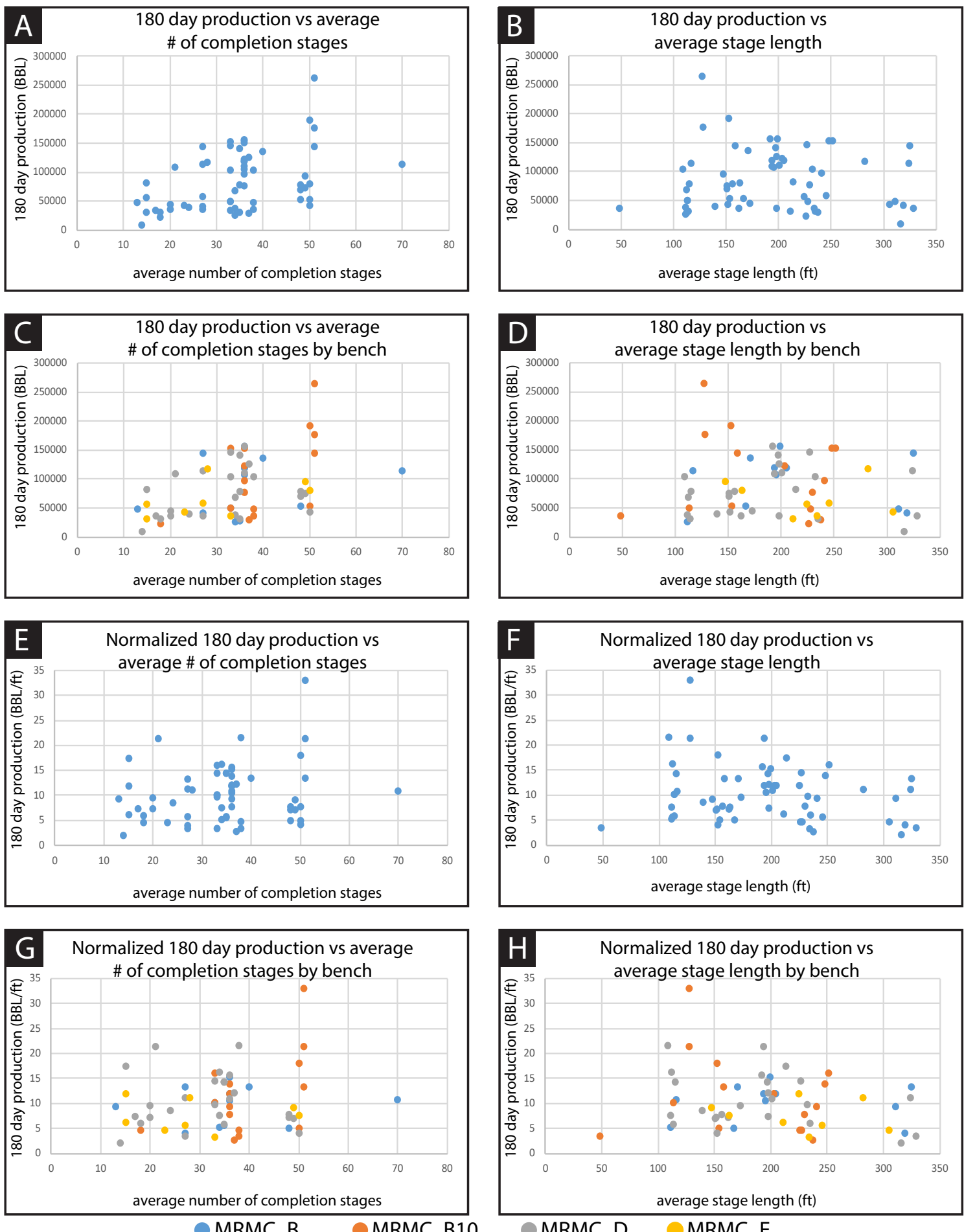

Appendix-E5: A) and B) are cross plots of non-normalized 180 day production versus average number of stages and average stage length respectively. C) and D) are the same cross plots, colored by bench. E) and F) are cross plots of normalized 180 day production versus average number of stages and average stage length respectively. $G$ ) and $H$ ) are the same cross plots, colored by bench. 